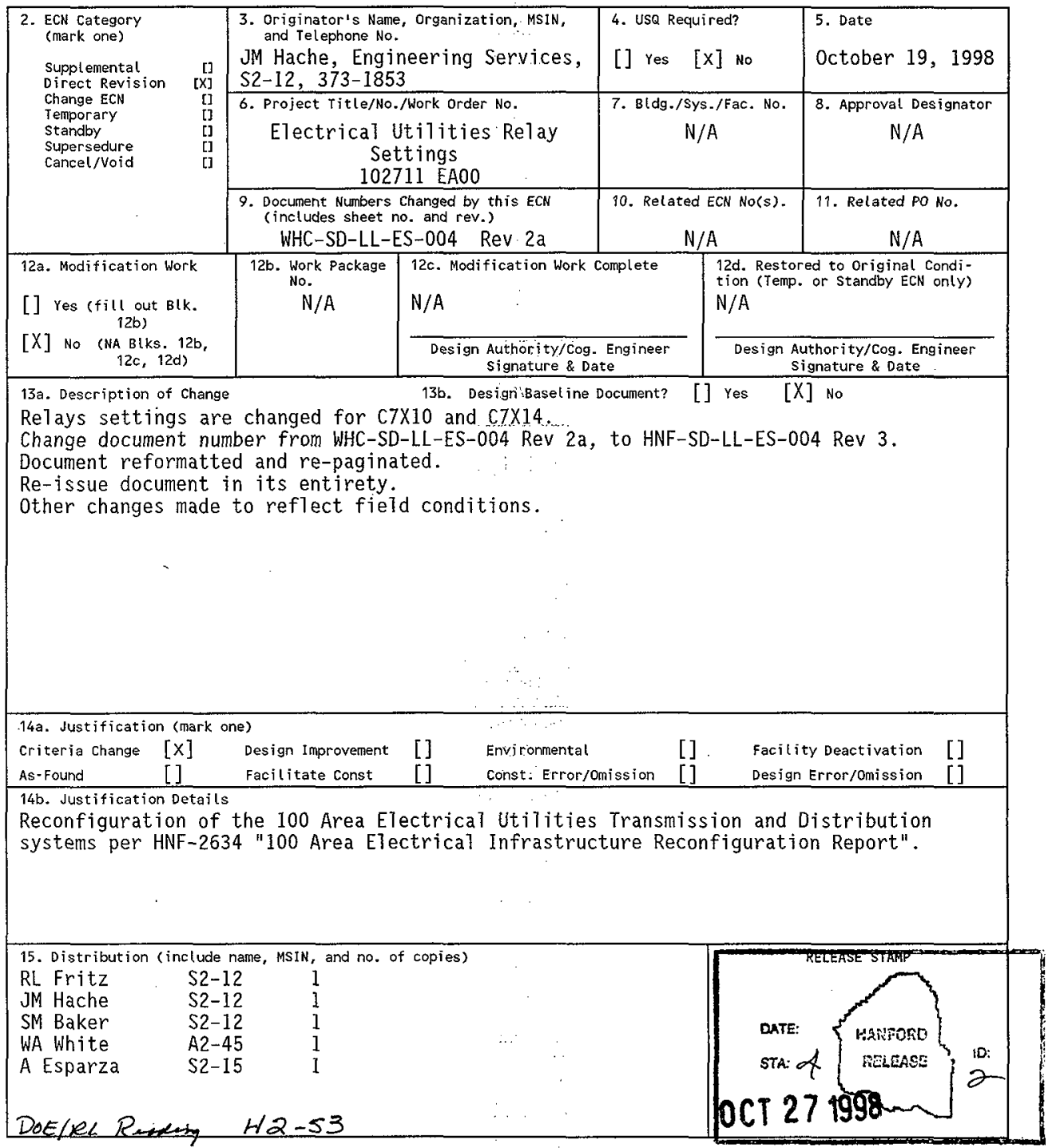



16. Design
Verification
Required
[] Yes [X] No

\author{
17. Cost Impact \\ ENGINEER ING
}

Additional

Savings

[] $\$$

CONSTRUCTION

19. Change Impact Review: Indicate the related documents (other than the engineering docunents identified on side 1 ) that will be affected by the change described in Block 13. Enter the affected document number in Block 20.

$$
\text { SDD/DD }
$$

Functional Design Criteria

Operating Specification

Criticality Specification

Conceptual Design Report

Equipment Spec.

Const. Spec.

Procurement Spec.

Vendor Information

OM Manual

FSAR/SAR

Safety Equipment List

Radiation Work Permit

Environmental Impact Statement

Environmental Report

Environmental Permit
[]
[]
[]
[]
[]
[]
[]
[]
[]
[]
[]
[]
[]
[]
[]
[]

[] Seismic/Stress Analysis

Interface Control Drawing

Calibration Procedure

[] Installation Procedure

[] Maintenance Procedure

[] Engineering Procedure

[] Operating Instruction

[] Operating Procedure

[] Operational Safety Requirement

[] IEFD Drawing

[] Cell Arrangement Drawing

[] Fac. Proc. Samp. Schedule

[] Inspection Plan

[] Inventory Adjustment Request
[]
[]
[]
[]
[]
[]
[]
[]
[]
[]
[]
[]
[]
[]
[]
[]

Tank Calibration Manual

Health Physics Procedure

Spares Multiple Unit Listing

Test Procedures/Specification

Component Index

ASME Coded item

Human Factor Consideration

Computer Software

Electric Circuit Schedule

ICRS Procedure

Process Control Manual/Plan

Process Flow Chart

Purchase Requisition

Tickler File

[]

20. Other Affected Documents: (NOTE: Documents listed below wilt not be revised by this ECN.) Signatures below indicate that the signing organization has been notified of other affected documents tisted below.

21. Approvals

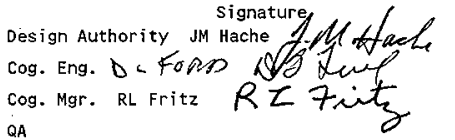

Safety

Environ.

other

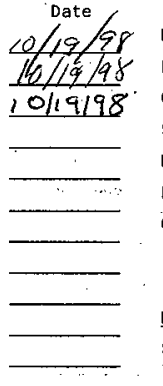

Design Agent

Signature

Date

PE

QA

Safety

Design

Environ.

other

DEPARTMENT OF ENERGY

Signature or a Control Number that

tracks the Approval signature

ADOITIONAL 


\section{Electrical Utilities Relay Settings}

JM Hache

DynCorp Tri-Cities Services, Inc., Richland, WA 99352

U.S. Department of Energy, Contract DE-AC06-96RL13200

EDT/ECN: /648731 UC: 900

Org Code: 52000

Charge Code: 102711 EA00

B\&R Code: YN0100000

Total Pages: 56

Key Words: Electrical Utilities Relay Settings

Abstract: This document contains the Hanford transmission and distribution system relay settings that are under the control of Electrical Utilities.

TRADEMARK DISCLAIMER. Reference herein to any specific comercial product, process, or service by trade name, trademark, manufacturer, or otherwise, does not necessarily constitute or imply its endorsement, recommendation, or favoring by the United states Government or any agency thereof or its contractors or subcontractors.

Printed in the United States of America. To obtain copies of this document, contact: Document Control Services, P.O. Box 950, Mailstop H6-08, Richland WA 99352, Phone (509) 372-2420; Fax (509) 376-4989.
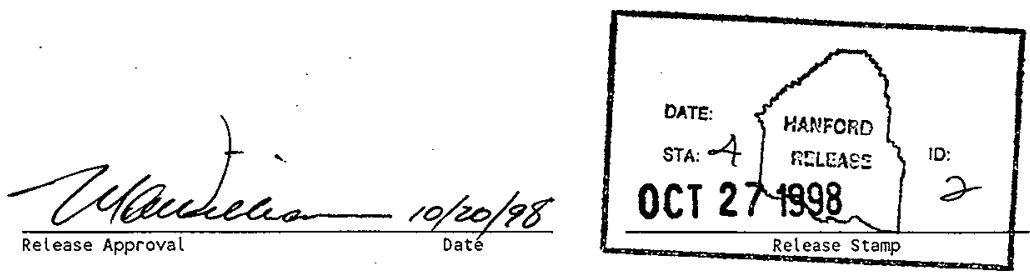

Approved for Public Release 
(2) Title

Electrical Utilities Relay Settings

CHANGE CONTROL RECORD

\begin{tabular}{|l|l|} 
(3) Revision & (4) Description of Change - Replace, Add, and Delete Pages \\
\hline 3 & $(7)$ \\
\hline RS. & $\begin{array}{l}\text { C7XI0,C7X14 and general update, rep Tace } \\
\text { entire document with Rev 3. ECN-648731 }\end{array}$ \\
\hline
\end{tabular}

Authorized for Release

(5) Cog. Engr. (6) Cog. Mgr. Date

\begin{tabular}{|l|r|l|l|}
\hline & & & \\
\hline & & & \\
\hline & $\ldots \ldots \ldots$ & & \\
\hline & $\ldots \ldots$ & & \\
\hline
\end{tabular}

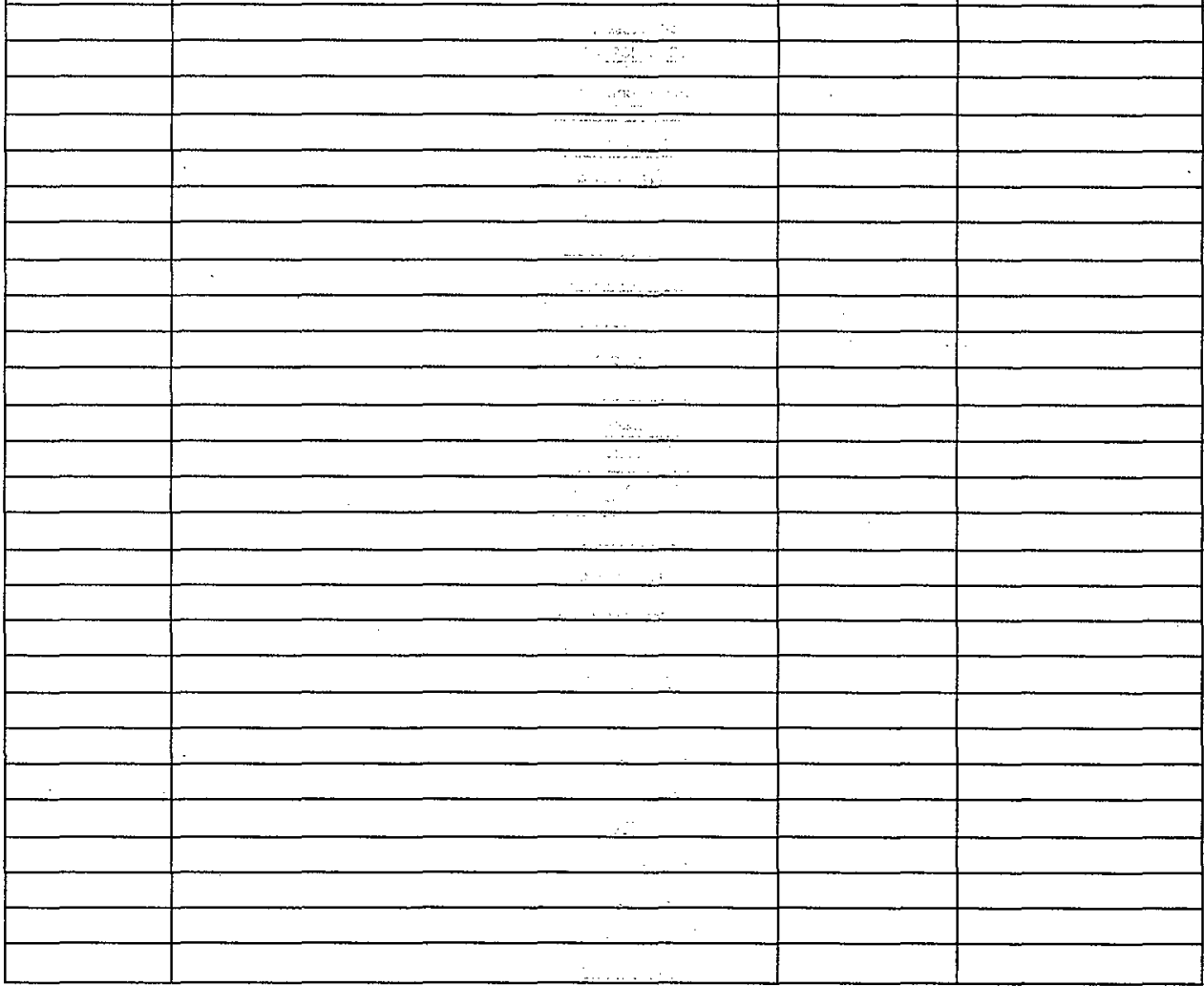




\section{HNF-SD-LL-ES-004 \\ ELECT́RICAL UTILITIES RELAY SETTINGS}

Revision 3, June 1998

Prepared for:

Dyncorp Tri-Cities Services, Inc.

P.O. Box 1400

Richland, Washington 99352 


\subsection{PURPOSE}

This supporting document provides a listing of the protective relay settings for the Electrical Utilities transmission and distribution systems.

\subsection{SCOPE}

The protective relay settings listed in this document apply to the electrical transmission and distribution systems under the administrative and operatinal control of Dyncorp Tri-Cities Services, Inc. Electrical Utilities Group. Facility protective relay settings should be obtained from the facility and will not be maintained in this document.

\subsection{SUMMARY}

This document has been divided into three appendices: Schweitzer Engineering Laboratories (SEL) relays and RFL Dowtey Model 6750 (RFL) relays; Transmission Relays; and Distribution Relays. The transmission relays are on the $230-\mathrm{kV}$ and $115-\mathrm{kV}$ tranmission systems and the distribution relays are on the 13.8-kV and $2.4-\mathrm{kV}$ distribution systems.

\subsection{TABLE OF CONTENTS}

APPENDIX A - SEL \& RFL Relay Settings

APPENDIX B - Transmission System Relay Settings

APPENDIX C - Distribution System Relay Settings 


\begin{tabular}{|c|c|c|c|c|c|c|}
\hline SUBSTATION & & \multirow[t]{2}{*}{ CIRCUIT } & \multirow{2}{*}{\multicolumn{3}{|c|}{$\begin{array}{l}\text { A7-MIDWAY LINE } \\
\text { (Hanford Line \#A1 and Line A2-7) }\end{array}$}} \\
\hline BREAKER & \multicolumn{2}{|c|}{ A-372 } & & & & \\
\hline $\begin{array}{l}\text { RELAY } \\
\text { FUNCTION }\end{array}$ & \multicolumn{6}{|c|}{$\begin{array}{l}\text { Transmission line protection using the SEL relays and RFL Dowety Model } 6750 \\
\text { ITTS relays to integrate a direct underreach, permissive overreach transfer trip } \\
\text { scheme with the Bonneville Power Administration protective relays at OCBS A- } \\
336 \text { (line breaker) or A-994 (bus-backup breaker). The relays also trip the A-372 } \\
\text { line breaker locally. These settings are adequate for bypass operation at } \\
\text { Substation A8. }\end{array}$} \\
\hline SEL 121G.5 & SET \#1 & SET \#2 & CT SETTING & $160: 1$ & PT SETTING & $2000-5$ \\
\hline Property Tag \# & FA25734 & FA23365 & POWER SUPPLY & $125 \mathrm{Vdc}$ & TIMECODE & IRIG-B \\
\hline Relay Serial \# & 40067 & 12028 & SECONDARY INPUTS & $\mathrm{V} / \phi=67 \mathrm{~L}$ & inal Amps $=5 \mathrm{~A}$ & $60 \mathrm{~Hz}$ \\
\hline Firmware Version & 403 & 109 & & & & \\
\hline
\end{tabular}

RELAY MASK - TYPICAL Row \#1: Relay Word Binary Representation

Row \#2: Relay Word Binary Representation

Row \#3: Relay Word Binary Representation

Row \#4: Relay Word Binary Representation

\begin{tabular}{|c|c|c|c|}
\hline 1 ABC & 2 ABC & $3 A B C$ & $4 A B C$ \\
\hline 1 & 0 & 0 & 0 \\
\hline $51 N T$ & $67 N 1$ & $67 N 2$ & $67 N 3$ \\
\hline 1 & 1 & 0 & 0 \\
\hline Z2PT & Z3PT & OSB & 3 P 50 \\
\hline 1 & 1 & 0 & 0 \\
\hline ALRM & TRIP & TC & DT \\
\hline 0 & 0 & 1 & 0 \\
\hline
\end{tabular}

\begin{tabular}{|c|c|c|c|}
\hline LOP & $50 \mathrm{H}$ & $50 \mathrm{M}$ & $50 \mathrm{~L}$ \\
\hline 0 & 0 & 0 & 0 \\
\hline $51 \mathrm{NP}$ & $\mathrm{Z} 1 \mathrm{P}$ & $\mathrm{Z} 2 \mathrm{P}$ & $\mathrm{Z3P}$ \\
\hline 0 & 1 & 0 & 0 \\
\hline $50 \mathrm{MF}$ & $\mathrm{RI}$ & $\mathrm{RC}$ & $\mathrm{DF}$ \\
\hline 1 & 0 & 0 & 0 \\
\hline $52 \mathrm{BT}$ & $\mathrm{Z} 3 \mathrm{X}$ & $\mathrm{Z} 2 \mathrm{GT}$ & $\mathrm{Z} 3 \mathrm{GT}$ \\
\hline 0 & 0 & 0 & 1 \\
\hline
\end{tabular}

Setting

\begin{tabular}{|c|c|}
\hline BINARY & HEXIDECIMAL \\
\hline 0000 & 0 \\
0001 & 1 \\
0010 & 2 \\
0011 & 3 \\
0100 & 4 \\
0101 & 5 \\
0110 & 6 \\
0111 & 7 \\
1000 & 8 \\
1001 & 9 \\
1010 & $\mathrm{~A}$ \\
1011 & $\mathrm{~B}$ \\
1100 & $\mathrm{C}$ \\
1101 & $\mathrm{D}$ \\
1110 & $\mathrm{E}$ \\
1111 & $\mathrm{~F}$ \\
\hline
\end{tabular}

\section{MASK SETTINGS}

\begin{tabular}{|c|c|c|c|c|c|c|c|c|c|}
\hline MTU & MPT & MTB & MTO & MA1 & MA2 & MA3 & MA4 & MRI & MRC \\
\hline 80 & 00 & 00 & C0 & 80 & 40 & 00 & 00 & 00 & 00 \\
\hline C4 & 00 & 00 & 66 & C4 & 22 & 00 & 00 & 00 & 00 \\
\hline C8 & 00 & 00 & 00 & C8 & 00 & 00 & 00 & 00 & 00 \\
\hline 20 & 00 & 00 & 00 & 20 & 00 & 00 & 00 & 00 & 00 \\
\hline
\end{tabular}

\section{MASK SETTING NOTES}

1. MTU is set to trip the A-372 locally and not actuate an integrated transfer trip.

2. MTO is set to for trip onto fault protection. This mask will trip A-372 locally and will not actuate an integrated transfer trip.

3. MT1 is set for direct underreach transfer trip.

4. MT2 is set for permissive overreach transfer trip.

5. MPT, MTB, MA3, MA4, MRI, and MRC are not used and are to be masked to 00 . 


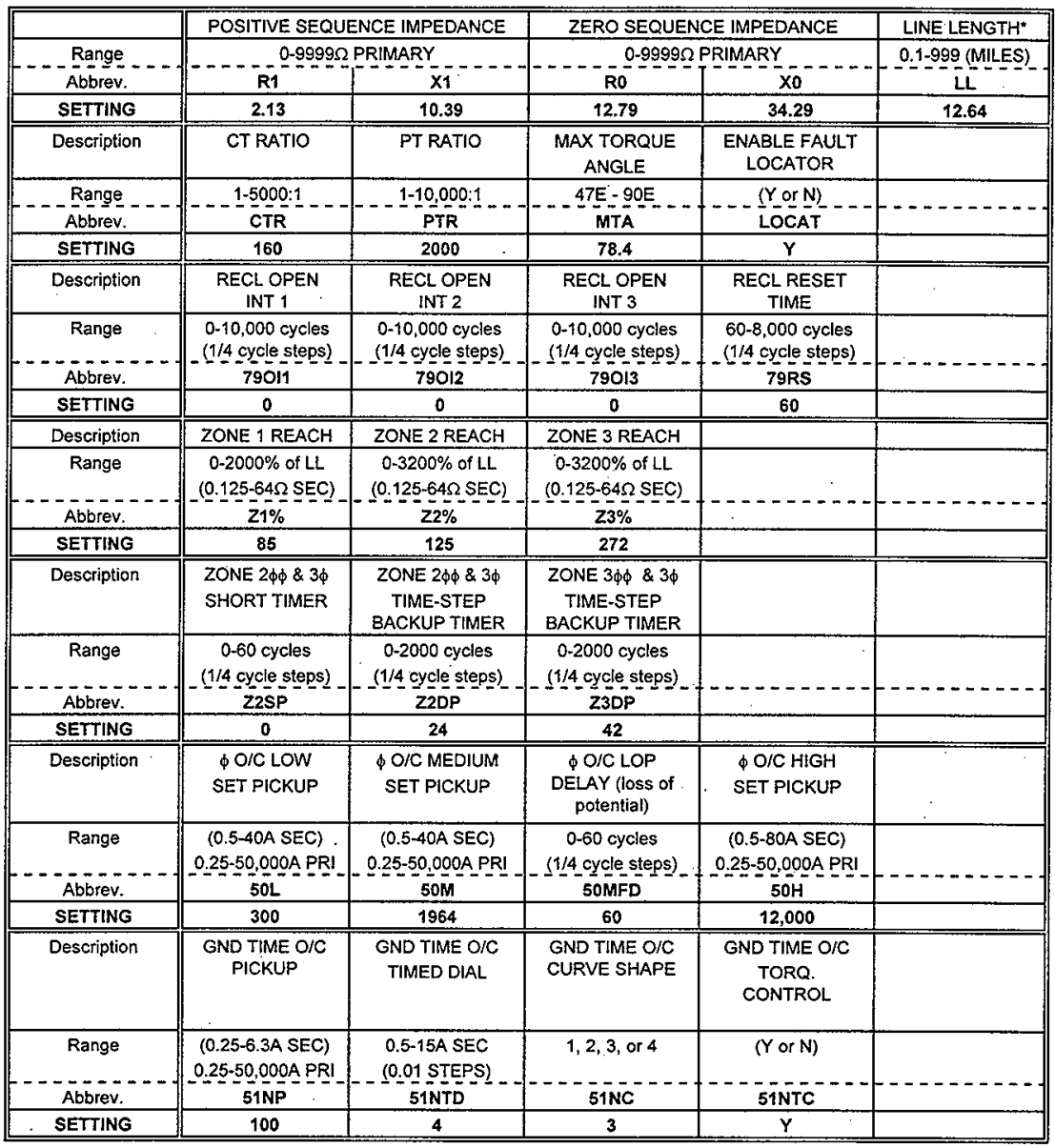




\begin{tabular}{|c|c|c|c|c|c|}
\hline Description & $\begin{array}{l}\text { ZONE } 1 \text { GND } \\
\text { INST. OIC }\end{array}$ & $\begin{array}{l}\text { ZONE } 2 \text { GND } \\
\text { INST. O/C }\end{array}$ & $\begin{array}{c}\text { ZONE } 3 \text { GND } \\
\text { INST. OIC }\end{array}$ & 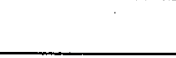 & \\
\hline $\begin{array}{l}\text { Range } \\
\text { Abbrev. }\end{array}$ & $\begin{array}{c}(0.25-48 \times 51 \mathrm{NP}) \\
0.25-50,000 \mathrm{~A} \text { PRI } \\
50 \mathrm{~N} / \mathrm{P}\end{array}$ & $\begin{array}{c}(0.25-48 \times 51 \mathrm{NP}) \\
0.25-50,000 \mathrm{~A} P R \mathrm{I} \\
50 \mathrm{~N} 2 \mathrm{P}\end{array}$ & $\begin{array}{c}(0.25-48 \times 51 \mathrm{NP}) \\
0.25-50,000 \mathrm{~A} P \mathrm{PR} \\
-50 \mathrm{~N} 3 \mathrm{P}\end{array}$ & & \\
\hline SETTING & 2150 & 1090 & 4800 & & \\
\hline Description & $\begin{array}{l}\text { ZONE } 2 \text { GND } \\
\text { SHORT TIMER }\end{array}$ & $\begin{array}{l}\text { ZONE } 2 \text { GND } \\
\text { TIME-STEP } \\
\text { BACKUP TIMER }\end{array}$ & $\begin{array}{c}\text { ZONE } 3 \text { GND } \\
\text { TIME-STEP } \\
\text { BACKUP TIMER }\end{array}$ & $\begin{array}{l}\text { MINIMUM TRIP } \\
\text { DURATION } \\
\text { TIMER }\end{array}$ & \\
\hline $\begin{array}{c}\text { Range } \\
-\overline{\text { Abbrev. }} \\
\end{array}$ & $\begin{array}{c}0-60 \text { cycles } \\
(1 / 4 \text { cycle steps }) \\
- \text { Z2SG }\end{array}$ & $\begin{array}{c}0-2,000 \text { cycles } \\
(1 / 4 \text { cycle steps }) \\
\text { Z2DG }\end{array}$ & $\begin{array}{c}0-2,000 \text { cycles } \\
(1 / 4 \text { cycle steps }) \\
- \text { Z3DG }\end{array}$ & $\begin{array}{c}0-2,000 \text { cycles } \\
(1 / 4 \text { cycle steps }) \\
\text { TDUR }\end{array}$ & \\
\hline SETTING & 0 & 0 & 2000 & 9 & \\
\hline Description & $\begin{array}{l}\text { 52BT TIME } \\
\text { DELAY }\end{array}$ & $\begin{array}{c}\text { ZONE } 3 \\
\text { DIRECTION }\end{array}$ & $\begin{array}{c}\text { GND O/C } \\
\text { NEGATIVE SEQ. } \\
\text { POLARIZATION }\end{array}$ & $\begin{array}{l}\text { GND O/C ZERO } \\
\text { SEQ. VOLTAGE } \\
\text { POLARIZATION }\end{array}$ & $\begin{array}{l}\text { GND OIC ZERO } \\
\text { SEQ. CURRENT } \\
\text { POLARIZATION }\end{array}$ \\
\hline $\begin{array}{l}\text { Range } \\
\text { Abbrev. }\end{array}$ & $0.5-10,000$ cycles & $\begin{array}{c}\text { (F OR R) } \\
\text { ZONE }^{--}\end{array}$ & $(\mathrm{Y}$ or $\mathrm{N})$ & $\begin{array}{c}(\mathrm{Y} \text { or } \mathrm{N}) \\
32 \mathrm{VE} \\
\end{array}$ & $($ (Y or $N)$ \\
\hline SETTING & 15 & $\mathbf{F}$ & $\mathbf{N}$ & $\mathbf{Y}$ & $Y$ \\
\hline Description & $\begin{array}{l}\text { OUT-OF-STEP } \\
\text { BLOCK FOR } \\
\text { ZONE } 1 \\
\end{array}$ & $\begin{array}{l}\text { OUT-OF-STEP } \\
\text { BLOCK FOR } \\
\text { ZONE } 2 \\
\end{array}$ & $\begin{array}{c}\text { OUT-OF-STEP } \\
\text { BLOCK FOR } \\
\text { ZONE } 3 \\
\end{array}$ & $\begin{array}{l}\text { OUT-OF-STEP } \\
\text { BLOCK TIMER }\end{array}$ & $\begin{array}{l}\text { LOSS-OF-POT. } \\
\text { ENABLE }\end{array}$ \\
\hline $\begin{array}{l}\text { Range } \\
\text { Abbrev. }\end{array}$ & $\begin{array}{c}(Y \text { or } N) \\
\text { OsBI }\end{array}$ & $\begin{array}{c}(Y \text { or } N) \\
\text { OSB2 } \\
\end{array}$ & $\begin{array}{c}(\mathrm{Y} \text { or } \mathrm{N}) \\
\mathrm{OSB} 3\end{array}$ & $\begin{array}{c}0.5-60 \text { cycles } \\
(1 / 4 \text { cycle steps }) \\
\text { OSBT }\end{array}$ & $\begin{array}{c}(\mathrm{Y} \text { or } \mathrm{N}) \\
\text { LOPE }\end{array}$ \\
\hline SETTING & $N$ & $\mathbf{N}$ & $\mathbf{N}$ & 30 & $Y$ \\
\hline Description & $\begin{array}{l}\text { SEL-121G-5 } \\
\text { PORT \#1 } \\
\text { TIMEOUT }\end{array}$ & $\begin{array}{l}\text { SEL-121G-5 } \\
\text { PORT \#2 } \\
\text { TIMEOUT }\end{array}$ & $\begin{array}{l}\text { AUTO MESSAGE } \\
\text { TRANSMIT } \\
\text { AUTOPORT } \\
\text { SELECTION }\end{array}$ & $\begin{array}{c}\text { \# RINGS AFTER } \\
\text { WHICH MODEM } \\
\text { ANSWERS }\end{array}$ & 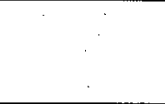 \\
\hline Abbrev. & (0-30 minutes) & $\begin{array}{l}(0-30 \text { minutes }) \\
\text { TIME2 }\end{array}$ & $\begin{array}{c}\begin{array}{c}\text { PORT 1,2 OR } 3 \\
\text { (BOTH) }\end{array} \\
\text { AUTO }\end{array}$ & $\begin{array}{c}1.30 \\
\text { RINGS }\end{array}$ & \\
\hline SETTING & 5 & 0 & 2 & 5 & \\
\hline
\end{tabular}




\begin{tabular}{|c|c|c|c|c|c|c|c|}
\hline SUBSTATION & \multicolumn{2}{|c|}{ A7 } & \multirow[t]{2}{*}{ CIRCUIT } & \multirow{2}{*}{\multicolumn{4}{|c|}{$\begin{array}{c}\text { A7-A8 ASHE THREE TERMINAL LINE } \\
\text { (Lines A7-9, A9-1, A1-4, A4-8) }\end{array}$}} \\
\hline BREAKER & \multicolumn{2}{|c|}{ A-376 } & & & & & \\
\hline $\begin{array}{c}\text { RELAY } \\
\text { FUNCTION }\end{array}$ & \multicolumn{7}{|c|}{$\begin{array}{l}\text { Transmission line protection utilizing RFL Dowety Model } 6750 \text { ITTS relays to } \\
\text { integrate a direct underreach, permissive overreach transfer trip scheme with the } \\
\text { Bonneville Power Administration protective relays at OCBs A-401 (line breaker) or } \\
\text { A-924 (bus-backup breaker), located at Ashe and OCB A-382 located at } \\
\text { substation A8. The relays also trip the A-376 line breaker locally. These settings } \\
\text { are adequate for bypass operation at Substation A8. }\end{array}$} \\
\hline SEL 121G.5 & SET \#1 & $\mathrm{SET} \# \mathbf{2}$ & \multicolumn{2}{|c|}{ CT SETTING } & $160: 1$ & PT SETTING & $2000-5$ \\
\hline Property Tag\# \# & FA25724 & FA23431 & \multicolumn{2}{|c|}{ POWER SUPPLY } & $125 \mathrm{Vdc}$ & TIMECODE & IRIG-B \\
\hline Relay Serial \# & 91339002 & 12030 & \multicolumn{2}{|c|}{ SECONDARY INPUTS } & \multicolumn{3}{|c|}{$\mathrm{V} / \phi=67 \mathrm{~L}-\mathrm{N} ; \mathrm{NOM}$ INAL AMPS $=5$ AMPS; $60 \mathrm{HZ}$} \\
\hline Firmware Version & 406 & 109 & & & & & \\
\hline
\end{tabular}

RELAY MASK - TYPICAL

\begin{tabular}{|c|c|c|c|c|c|c|c|c|c|}
\hline ROW\#1: RELAY WORD & $1 \mathrm{ABC}$ & $2 A B C$ & $3 \mathrm{ABC}$ & $\triangle A B C$ & LOP & $50 \mathrm{H}$ & $50 \mathrm{M}$ & $50 \mathrm{~L}$ & \multirow[t]{2}{*}{80} \\
\hline BINARY REPRESENTATION & 1 & 0 & 0 & 0 & 0 & 0 & 0 & 0 & \\
\hline \multirow{2}{*}{$\begin{array}{l}\text { ROW \#2: RELAY WORD } \\
\text { BINARY REPRESENTATION }\end{array}$} & $51 \mathrm{NT}$ & $67 \mathrm{N1}$ & $67 \mathrm{~N} 2$ & $67 \mathrm{N3}$ & $51 \mathrm{NP}$ & $\mathrm{Z1P}$ & $\mathrm{Z2P}$ & $\mathrm{Z3P}$ & \multirow[t]{2}{*}{$\mathrm{C} 4$} \\
\hline & 1 & 1 & 0 & 0 & 0 & 1 & 0 & 0 & \\
\hline \multirow{2}{*}{$\begin{array}{l}\text { ROW \#3: RELAY WORD } \\
\text { BINARY REPRESENTATION }\end{array}$} & Z2PT & Z3PT & OSB & $3 \mathrm{P} 50$ & 50MF & RI & $R C$ & DF & \multirow[t]{2}{*}{$\mathrm{C8}$} \\
\hline & 1 & 1 & 0 & 0 & 1 & 0 & 0 & 0 & \\
\hline \multirow{2}{*}{$\begin{array}{l}\text { ROW \#4: RELAY WORD } \\
\text { BINARY REPRESENTATION }\end{array}$} & ALRM & TRIP & TC & DT & 52BT & $23 x$ & $\mathrm{Z2GT}$ & Z3GT & \multirow[t]{2}{*}{21} \\
\hline & 0 & 0 & 1 & 0 & 0 & 0 & 0 & 1 & \\
\hline
\end{tabular}

\begin{tabular}{|c|c|}
\hline BINARY & HEXIDECIMAL \\
\hline 0000 & 0 \\
0001 & 1 \\
0010 & 2 \\
0011 & 3 \\
0100 & 4 \\
0101 & 5 \\
0110 & 6 \\
0111 & 7 \\
1000 & 8 \\
1001 & 9 \\
1010 & A \\
1011 & B \\
1100 & C \\
1101 & D \\
1110 & E \\
1111 & F \\
\hline
\end{tabular}

MASK SETTINGS
\begin{tabular}{|c|c|c|c|c|c|c|c|c|c|}
\hline MTU & MPT & MTB & MTO & MA1 & MA2 & MA3 & MA4 & MR1 & MRC \\
\hline 80 & 00 & 00 & C0 & 80 & 40 & 00 & 00 & 00 & 00 \\
\hline C4 & 00 & 00 & 66 & $C 4$ & 22 & 00 & 00 & 00 & 00 \\
\hline $\mathrm{C} 8$ & 00 & 00 & 00 & $\mathrm{C} 8$ & 00 & 00 & 00 & 00 & 00 \\
\hline 20 & 00 & 00 & 00 & 20 & 00 & 00 & 00 & 00 & 00 \\
\hline
\end{tabular}

\section{MASK SETTING NOTES}

1. MTU is set to trip the A-376 locally and not actuate an integrated transfer trip.

2. MTO is set to for trip onto fault protection. It will only trip A-376 locally and will not actuate an integrated transfer trip.

3. MT1 is set for direct underreach transfer trip.

4. MT2 is set for permissive overreach transfer trip. 


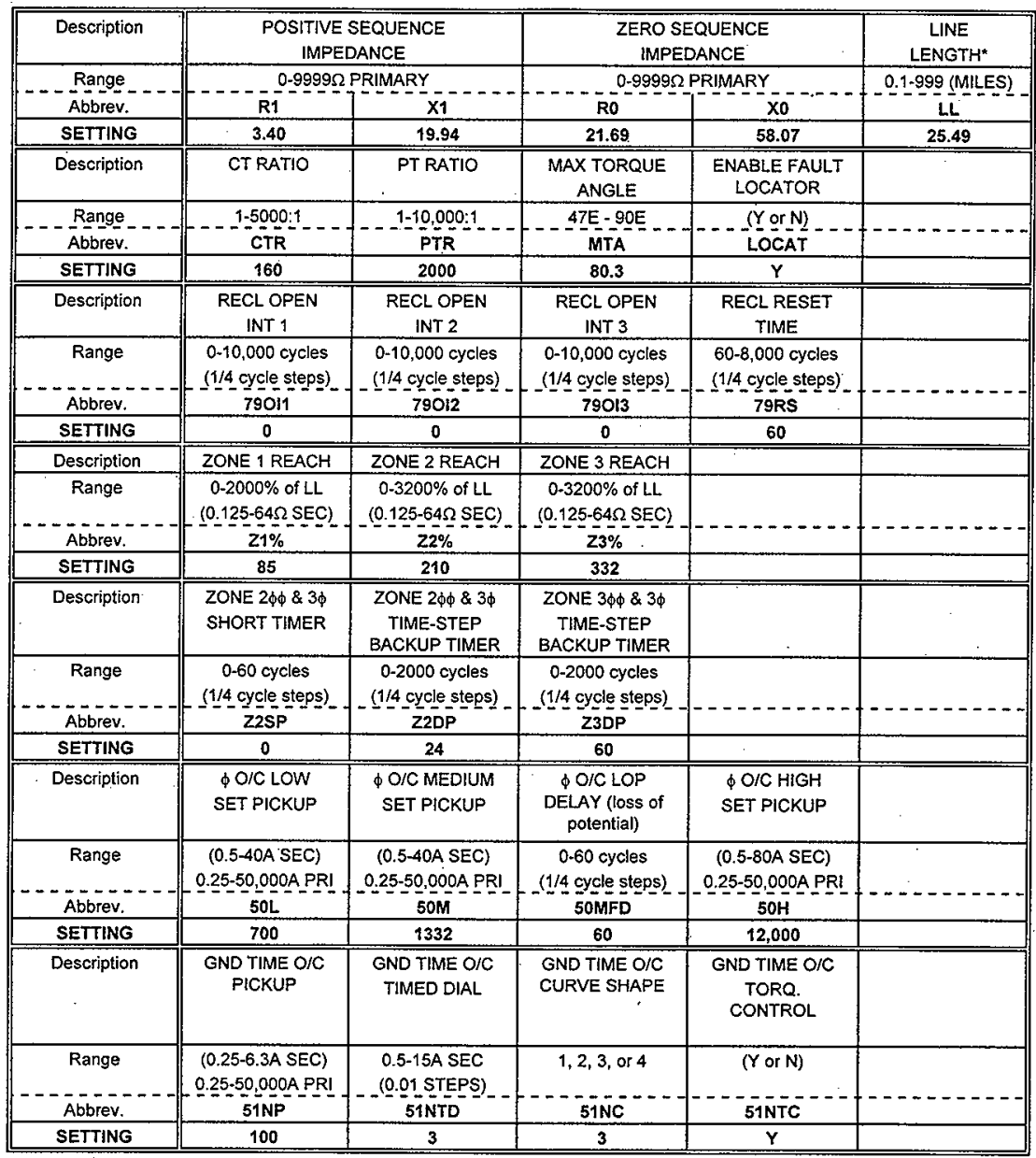




\begin{tabular}{|c|c|c|c|c|c|}
\hline Description & $\begin{array}{l}\text { ZONE I GND } \\
\text { INST. O/C }\end{array}$ & $\begin{array}{l}\text { ZONE } 2 \text { GND } \\
\text { INST. O/C }\end{array}$ & $\begin{array}{l}\text { ZONE } 3 \text { GND } \\
\text { INST. O/C }\end{array}$ & & \\
\hline $\begin{array}{l}\text { Range } \\
\text { Abbrev. }\end{array}$ & $\begin{array}{c}(0.25-48 \times 51 N P) \\
0.25-50,000 A \text { PRI } \\
50 \mathrm{N1P}\end{array}$ & $\begin{array}{c}(0.25-48 \times 51 \mathrm{NP}) \\
0.25-50,000 \mathrm{~A} \\
50 \mathrm{~N} 2 \mathrm{P}\end{array}$ & $\begin{array}{c}(0.25-48 \times 51 \mathrm{NP}) \\
0.25-50,000 \mathrm{~A} P R \mathrm{I} \\
-50 \mathrm{~N} 3 \mathrm{P}\end{array}$ & $-\cdots$ & \\
\hline SETTING & 1715 & 741 & 4800 & & \\
\hline $\begin{array}{c}\text { Description } \\
\text {. }\end{array}$ & $\begin{array}{l}\text { ZONE } 2 \text { GND } \\
\text { SHORT TIMER }\end{array}$ & $\begin{array}{c}\text { ZONE } 2 \text { GND } \\
\text { TIME-STEP } \\
\text { BACKUP TIMER } \\
\end{array}$ & $\begin{array}{l}\text { ZONE } 3 \text { GND } \\
\text { TIME-STEP } \\
\text { BACKUP TIMER }\end{array}$ & $\begin{array}{l}\text { MINIMUM TRIP } \\
\text { DURATION } \\
\text { TIMER }\end{array}$ & \\
\hline $\begin{array}{c}\text { Range } \\
\text { Abbrev. } \\
\end{array}$ & $\begin{array}{c}0.60 \text { cycies } \\
(1 / 4 \text { cycle steps }) \\
\text { Z2SG }\end{array}$ & $\begin{array}{c}0-2,000 \text { cycles } \\
(1 / 4 \text { cycle steps) } \\
\text { Z2DG }\end{array}$ & $\begin{array}{c}0-2,000 \text { cycles } \\
(1 / 4 \text { cycle steps }) \\
\text { Z3DG }\end{array}$ & $\begin{array}{c}0-2,000 \text { cycles } \\
\text { (1/4_cycle steps) } \\
\text { TDUR }\end{array}$ & \\
\hline SETTING & 0 & 0 & 2000 & 9 & \\
\hline Description & 52BT TIME DELAY & $\begin{array}{c}\text { ZONE } 3 \\
\text { DIRECTION }\end{array}$ & $\begin{array}{c}\text { GND OIC } \\
\text { NEGATIVE SEQ. } \\
\text { POLARIZATION }\end{array}$ & $\begin{array}{l}\text { GND O/C ZERO } \\
\text { SEQ. VOLTAGE } \\
\text { POLARIZATION }\end{array}$ & $\begin{array}{l}\text { GND OIC ZERO } \\
\text { SEQ. CURRENT } \\
\text { POLARIZATION } \\
\end{array}$ \\
\hline$=\frac{\text { Range }}{\text { Abbrev. }}$ & $0.5-10,000$ eycles & $-\frac{(F \text { OR R })}{\text { ZONE } 3}$ & $\frac{(\mathrm{Y} \text { or } \mathrm{N})}{32 \mathrm{QE}}$ & $\ldots$ (Y or $N)$ & $-\frac{(Y \text { or } N)}{32 \text { IE }}$ \\
\hline SETTING & 15 & $F$ & $N$ & $\mathrm{Y}$ & $Y$ \\
\hline Description & $\begin{array}{l}\text { OUT-OF-STEP } \\
\text { BLOCK FOR } \\
\text { ZONE } 1 \\
\end{array}$ & $\begin{array}{l}\text { OUT-OF-STEP } \\
\text { BLOCK FOR } \\
\text { ZONE } 2 \\
\end{array}$ & $\begin{array}{l}\text { OUT-OF-STEP } \\
\text { BLOCK FOR } \\
\text { ZONE } 3 \\
\end{array}$ & $\begin{array}{l}\text { OUT-OF-STEP } \\
\text { BLOCK TIMER }\end{array}$ & $\begin{array}{l}\text { LOSS-OF-POT. } \\
\text { ENABLE }\end{array}$ \\
\hline $\begin{array}{c}\text { Range } \\
\text { Abbrev. } \\
\end{array}$ & $\begin{array}{l}(\mathrm{Y} \text { or } \mathrm{N}) \\
\mathrm{OSB1}\end{array}$ & $\begin{array}{c}(Y \text { or } N) \\
\text { osB2 }\end{array}$ & $\begin{array}{r}(Y \text { or } \mathrm{N}) \\
\text { osB3 } \\
\end{array}$ & $\begin{array}{c}\text { 0.5-60 cycles } \\
(1 / 4 \text { cycle steps) } \\
\text { OSBT }\end{array}$ & $\begin{array}{c}\text { (Y or } N \text { ) } \\
\text { LOPE } \\
\end{array}$ \\
\hline SETTING & $\mathbf{N}$ & $\mathbf{N}$ & $\mathbf{N}$ & 30 & $Y$ \\
\hline Description & $\begin{array}{l}\text { SEL-121G-5 } \\
\text { PORT \#1 } \\
\text { TIMEOUT }\end{array}$ & $\begin{array}{l}\text { SEL-121G-5 } \\
\text { PORT \#2 } \\
\text { TIMEOUT }\end{array}$ & $\begin{array}{c}\text { AUTO MESSAGE } \\
\text { TRANSMIT } \\
\text { AUTOPORT } \\
\text { SELECTION }\end{array}$ & $\begin{array}{l}\text { \# RINGS AFTER } \\
\text { WHICH MODEM } \\
\text { ANSWERS }\end{array}$ & . \\
\hline Abbrev. & (0-30 minutes) & $\begin{array}{l}\text { (0-30 minutes) } \\
\text { TIME2 }\end{array}$ & $\begin{array}{l}\text { PORT 1,2 OR } 3 \\
\text { (BOTH) }\end{array}$ & $\begin{array}{c}1-30 \\
\text { RINGS } \\
\end{array}$ & \\
\hline SETTING & 5 & 0 & 2 & 5 & \\
\hline
\end{tabular}




\begin{tabular}{|c|c|c|c|c|c|c|c|c|c|c|}
\hline \multirow{2}{*}{\multicolumn{2}{|c|}{$\begin{array}{c}\text { SUBSTATION } \\
\text { BREAKER } \\
\end{array}$}} & \multirow{2}{*}{\multicolumn{2}{|c|}{$\frac{A 8}{A-382}$}} & \multirow{2}{*}{\multicolumn{2}{|c|}{ CIRCUIT }} & \multirow{2}{*}{\multicolumn{5}{|c|}{$\begin{array}{c}\text { A7-A8-ASHE 3-TERMINAL LINE } \\
\text { (Lines A7-9, A9-1, A1-4, A4-8) }\end{array}$}} \\
\hline & & & & & & & & & & \\
\hline $\begin{array}{l}\text { RELAY } \\
\text { FUNCTION }\end{array}$ & \multicolumn{10}{|c|}{$\begin{array}{l}\text { Transmission line protection. utilizing RFL Dowety Model } 6750 \text { ITTS relays to } \\
\text { integrate a direct underreach, permissive overreach transfer trip scheme with the } \\
\text { Bonneville Power Administration protective relays at OCBs A-401 (line breaker) } \\
\text { or A-924 (bus-backup breaker), located at Ashe substation and OCB A-376 } \\
\text { located at substation A7. The relays also trip the A-382 line breaker locally. } \\
\text { These settings are adequate for bypass operation at Substation A7. }\end{array}$} \\
\hline SEL 121G-5 & SET \#1 & SET \# & & \multicolumn{2}{|c|}{ ST SETTING. } & \multicolumn{2}{|c|}{$160: 1$} & \multicolumn{2}{|c|}{ PT SETTING } & $2000-5$ \\
\hline Property Tag \# & FA25729 & FA23577 & & \multicolumn{2}{|c|}{ WER SUPPLY } & \multicolumn{2}{|c|}{$125 \mathrm{Vdc}$} & \multicolumn{2}{|c|}{ TIMECODE } & IRIG-B \\
\hline Relay Serial \# & 91337024 & 12032 & \multicolumn{3}{|c|}{ SECONDARY INPUTS } & \multicolumn{5}{|c|}{ V/ $\phi=67 \mathrm{~L}-\mathrm{N} ;$ NOMINAL AMPS $=5$ AMPS; $60 \mathrm{HZ}$} \\
\hline Firmware Version & 406 & 109 & & & & & & & & \\
\hline \multicolumn{10}{|c|}{ RELAY MASK - TYPICAL } & SETTING \\
\hline \multirow{2}{*}{\multicolumn{2}{|c|}{$\begin{array}{l}\text { ROW \#1: RELAY WORD } \\
\text { BINARY REPRESENTATION }\end{array}$}} & $1 A B C$ & $2 A B C$ & 3ABC & 4ABC & LOP & $50 \mathrm{H}$ & $50 \mathrm{M}$ & $50 \mathrm{~L}$ & \multirow[t]{2}{*}{80} \\
\hline & & 1 & 0 & 0 & 0 & 0 & 0 & 0 & 0 & \\
\hline \multirow{2}{*}{\multicolumn{2}{|c|}{ ROW \#2: RELAY WORD }} & $51 \mathrm{NT}$. & $67 \mathrm{N1}$ & $67 \mathrm{~N} 2$ & $67 \mathrm{N3}$ & $51 \mathrm{NP}$ & Z1P & Z2P & $\mathrm{Z3P}$ & \multirow[t]{2}{*}{$\mathrm{C4}$} \\
\hline & & 1 & 1 & 0 & 0 & 0 & 1 & 0 & 0 & \\
\hline \multirow{2}{*}{\multicolumn{2}{|c|}{ ROW \#3: RELAY WORD }} & Z2PT & Z3PT & OSB & $3 P 50$ & 50MF & $\mathrm{RI}$ & $\mathrm{RC}$ & DF & \multirow[t]{2}{*}{$\mathrm{CB}$} \\
\hline & & 1 & 1 & 0 & 0 & 1 & 0 & 0 & 0 & \\
\hline \multirow{2}{*}{\multicolumn{2}{|c|}{ ROW \#4: RELAY WORD }} & ALRM & TRIP & TC & DT & $52 \mathrm{BT}$ & $23 X$ & Z2GT & Z3GT & \multirow[t]{2}{*}{21} \\
\hline & & 0 & 0 & 1 & 0 & 0 & 0 & 0 & 1 & \\
\hline
\end{tabular}

\begin{tabular}{|c|c|}
\hline BINARY & HEXIDECIMAL \\
\hline 0000 & 0 \\
0001 & 1 \\
0010 & 2 \\
0011 & 3 \\
0100 & 4 \\
0101 & 5 \\
0110 & 6 \\
0111 & 7 \\
1000 & 8 \\
1001 & 9 \\
1010 & A \\
1011 & B \\
1100 & C \\
1101 & $D$ \\
1110 & E \\
1111 & $F$ \\
\hline
\end{tabular}

MASK SETTINGS

\begin{tabular}{|c|c|c|c|c|c|c|c|c|c|}
\hline MTU & MPT & MTB & MTO & MA1 & MA2 & MA3 & MA4 & MRI & MRC \\
\hline 80 & 00 & 00 & C0 & 80 & 40 & 00 & 00 & 00 & 00 \\
\hline C4 & 00 & 00 & 66 & C4 & 22 & 00 & 00 & 00 & 00 \\
\hline C8 & 00 & 00 & 00 & C8 & 00 & 00 & 00 & 00 & 00 \\
\hline 20 & 00 & 00 & 00 & 20 & 00 & 00 & 00 & 00 & 00 \\
\hline
\end{tabular}

MASK SETTING NOTES

1. MTU is set to trip the A-382 locally and not actuate an integrated transfer trip.

2. MTO is set to for trip onto fault protection. This mask will trip A-382 locally and will not actuate an integrated transfer trip.

3. MT1 is set for direct underreach transfer trip.

4. MT2 is set for permissive overteach transfer trip.

5. MPT, MTB, MA3, MA4, MRI, and MRC are not used and are to be masked to 00 . 


\begin{tabular}{|c|c|c|c|c|c|}
\hline Description & \multicolumn{2}{|c|}{$\begin{array}{c}\text { POSITIVE SEQUENCE } \\
\text { IMPEDANCE }\end{array}$} & \multicolumn{2}{|c|}{$\begin{array}{c}\text { ZERO SEQUENCE } \\
\text { IMPEDANCE }\end{array}$} & $\begin{array}{c}\text { LINE } \\
\text { LENGTH* }\end{array}$ \\
\hline Range & $0-9999 \Omega$ & DRIMARY & $0-9999 \Omega$ & RIMARY & $0.1-999$ (MILES) \\
\hline Abbrev. & R1 & $\mathrm{X} 1$ & Ro & $x_{0}$ & $\mathrm{LL}$ \\
\hline SETTING & 1.86 & 13.67 & 12.80 & 34.26 & 16.11 \\
\hline Description & CT RATIO & PT RATIO & $\begin{array}{l}\text { MAX TORQUE } \\
\text { ANGLE }\end{array}$ & $\begin{array}{l}\text { ENABLE FAULTT } \\
\text { LOCATOR }\end{array}$ & \\
\hline$-\frac{\text { Range }}{\text { Abbrev. }}$ & $-\frac{1-5000: 1}{\text { CTR }}$ & 1-10,000:1 & $-47 \mathrm{E}=90 \mathrm{E}$ & $-\left(\frac{(Y \text { or } N)}{\text { LOCAT }}-\cdots\right.$ & \\
\hline SETTING & 160 & 2000 & 82.3 & $\bar{Y}$ & \\
\hline Description & $\begin{array}{l}\text { RECL OPEN } \\
\text { INT } 1\end{array}$ & $\begin{array}{l}\text { RECL OPEN } \\
\text { INT } 2\end{array}$ & $\begin{array}{l}\text { RECL OPEN } \\
\text { INT } 3\end{array}$ & $\begin{array}{c}\text { RECL RESET } \\
\text { TIME }\end{array}$ & \\
\hline $\begin{array}{c}\text { Range } \\
\text { Abbrev. } \\
\end{array}$ & $\begin{array}{c}0-10,000 \text { cycles } \\
\text { (1/4_cycle steps) } \\
79011\end{array}$ & $\begin{array}{c}0-10,000 \text { cycles } \\
(1 / 4 \text { cycle steps }) \\
790: 2\end{array}$ & $\begin{array}{c}0-10,000 \text { cycles } \\
(1 / 4 \text { cycle steps) } \\
79013\end{array}$ & $\begin{array}{c}60-8,000 \text { cycles } \\
-(1 / 4 \text { cycle steps) } \\
79 \text {. }\end{array}$ & \\
\hline SETTING & 0 & 0 & 0 & 60 & \\
\hline Description & ZONE 1 REACH & ZONE 2 REACH & ZONE 3 REACH & & \\
\hline $\begin{array}{l}\text { Range } \\
\text { Abbrev. } \\
\end{array}$ & $\begin{array}{c}0.2000 \% \text { of } L L \\
(0.125-64 \Omega \Omega \\
Z 1 \%\end{array}$ & $\begin{array}{c}0-3200 \% \text { of } L L \\
(0.125-64 \Omega \Omega S E C) \\
Z 2 \%\end{array}$ & $\begin{array}{c}0-3200 \% \text { of } L L \\
(0.125-64 \Omega \text { SEC }) \\
Z 3 \%\end{array}$ & & \\
\hline SETTING & 85 & 226 & 266 & & \\
\hline Description & $\begin{array}{l}\text { ZONE } 2 \phi \phi \& 3 \phi \\
\text { SHORT TIMER }\end{array}$ & $\begin{array}{l}\text { ZONE } 2 \phi \phi \& 3 \phi \\
\text { TIME-STEP } \\
\text { BACKUP TIMER }\end{array}$ & $\begin{array}{c}\text { ZONE } 3 \phi \phi \& 3 \phi \\
\text { TIME-STEP } \\
\text { BACKUP TIMER }\end{array}$ & & \\
\hline $\begin{array}{l}\text { Range } \\
\text { Ábbrev. } \\
\end{array}$ & $\begin{array}{c}0-60 \text { cycles } \\
(1 / 4 \text { cycle steps }) \\
\text { Z2SP }\end{array}$ & $\begin{array}{c}0-2000 \text { cycles } \\
(1 / 4 \text { cycle steps }) \\
\text { Z22DP }\end{array}$ & $\begin{array}{c}0-2000 \text { cycles } \\
(1 / 4 \text { cycle steps) } \\
\text { Z30p }\end{array}$ & & \\
\hline SETTING & 0 & 24 & 60 & & \\
\hline Description & $\begin{array}{l}\text { \&O/C LOW } \\
\text { SET PICKUP }\end{array}$ & $\begin{array}{l}\phi \text { O/C MEDIUM } \\
\text { SET PICKUP }\end{array}$ & $\begin{array}{c}\phi O / C \text { LOP } \\
\text { DELAY (loss of } \\
\text { potential) }\end{array}$ & $\begin{array}{l}\$ O / C \text { HIGH } \\
\text { SET PICKUP }\end{array}$ & . \\
\hline $\begin{array}{l}\text { Range } \\
\text { Äbbrev. }\end{array}$ & $\begin{array}{c}(0.5-40 A \text { SEC) } \\
0.25-50,000 \mathrm{~A} P R ! \\
50 \mathrm{~L}\end{array}$ & $\begin{array}{c}(0.5-40 \mathrm{~A} \text { SEC) } \\
0.25-50,000 \mathrm{~A} \text { PRI } \\
50 \mathrm{M}\end{array}$ & $\begin{array}{c}0-60 \text { cycles } \\
(1 / 4 \text { cycle steps }) \\
50 \mathrm{MFD}\end{array}$ & $\begin{array}{c}(0.5-80 \mathrm{~A} \text { SEC) } \\
0.25-50,000 \mathrm{~A} \text { PRI } \\
50 \mathrm{H}\end{array}$ & \\
\hline SETTING & 700 & 2212 & 60 & 12,000 & \\
\hline Description & $\begin{array}{l}\text { GND TIME O/C } \\
\text { PICKUP }\end{array}$ & $\begin{array}{l}\text { GND TIME O/C } \\
\text { TIMED DIAL }\end{array}$ & $\begin{array}{l}\text { GND TIME O/C } \\
\text { CURVE SHAPE }\end{array}$ & $\begin{array}{c}\text { GND TIME O/C } \\
\text { TORQ. } \\
\text { CONTROL } \\
\end{array}$ & \\
\hline Range & $\begin{array}{c}(0.25-6.3 \mathrm{~A} \text { SEC) } \\
0.25-50,000 \mathrm{APR} \\
-51 \mathrm{NP}\end{array}$ & $\begin{array}{c}0.5-15 A \text { SEC } \\
\text { (0.01 STEPS) } \\
\text { 5 NTTD }\end{array}$ & $\begin{array}{l}1,2,3, \text { or } 4 \\
51 \mathrm{NC}\end{array}$ & $(\mathrm{V}$ or $\mathrm{N})$ & \\
\hline SETTING & 240 & 2.75 & 3 & $Y$ & \\
\hline
\end{tabular}




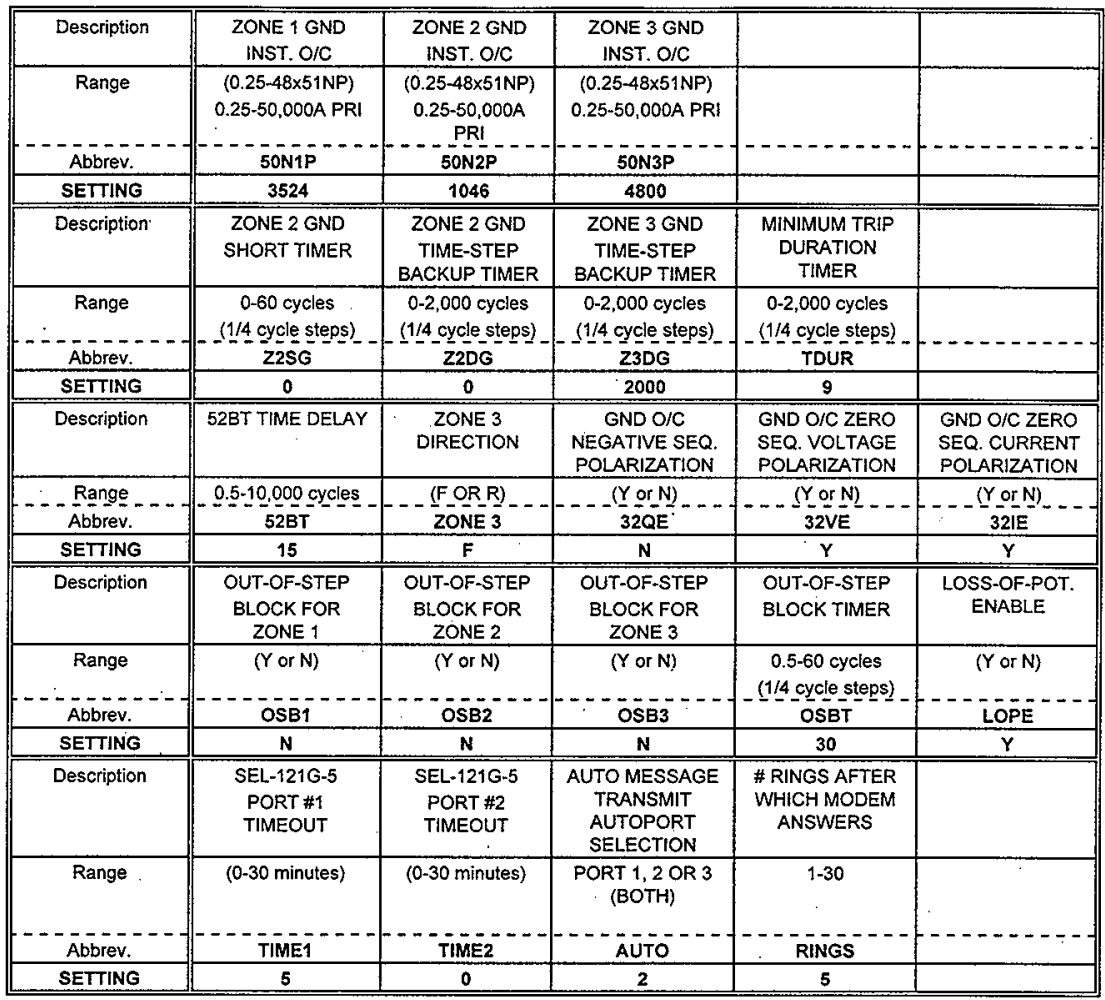

\section{Comments}




\begin{tabular}{|c|c|c|c|c|c|c|c|c|c|c|}
\hline SUBSTATION & \multicolumn{2}{|c|}{$A 8$} & \multirow{2}{*}{\multicolumn{2}{|c|}{ CIRCUIT }} & \multirow{2}{*}{\multicolumn{6}{|c|}{$\begin{array}{l}\text { A8-MiDWAY LINE } \\
\text { (Hanford Line \#A2) }\end{array}$}} \\
\hline BREAKER & \multicolumn{2}{|c|}{ A-386 } & & & & & & & & \\
\hline $\begin{array}{l}\text { RELAY } \\
\text { FUNCTION }\end{array}$ & \multicolumn{10}{|c|}{$\begin{array}{l}\text { Transmission line protection utilizing RFL Dowety Model } 6750 \text { ITTS relays to } \\
\text { integrate a direct underreach, permissive overreach transfer trip scheme with the } \\
\text { Bonneville Power Administration protective relays at OCBs A-336 (line breaker) or } \\
\text { A-68 (bus-backup breaker), located at Midway substation. The relays also trip the } \\
\text { A-386 line breaker locally. These settings are adequate for bypass operation at } \\
\text { Substation A7. }\end{array}$} \\
\hline SEL 121G-5 & SET \#1 & SET \#2 & \multicolumn{3}{|c|}{ CT SETTING } & \multicolumn{2}{|c|}{$160: 1$} & \multicolumn{2}{|c|}{ PT SETTING } & $2000-5$ \\
\hline Property Tag \# & FA25733 & FA23576 & \multicolumn{3}{|c|}{ POWER SUPPLY } & \multicolumn{2}{|c|}{$125 \mathrm{Vdc}$} & \multicolumn{2}{|c|}{ TIMECODE } & IRIG-B \\
\hline Relay Serial \# & 91337023 & 12031 & & \multicolumn{5}{|c|}{$\mathrm{V} / \phi=67 \mathrm{~L}-\mathrm{N} ;$ NOMINAL AMPS $=5$ AMPS; $60 \mathrm{HZ}$} \\
\hline Firmware Version & 406 & 109 & & \multicolumn{2}{|c|}{ SECONDARY INPUTS } & & & & & \\
\hline \multicolumn{10}{|c|}{ RELAY MASK - TYPICAL } & SETTING \\
\hline \multirow{2}{*}{\multicolumn{2}{|c|}{$\begin{array}{l}\text { ROW\#1: RELAY WORD } \\
\text { BINARY REPRESENTATION }\end{array}$}} & TABC & $2 A B C$ & $3 A B C$ & $4 \mathrm{ABC}$ & LOP & $50 \mathrm{H}$ & $50 \mathrm{M}$ & $50 \mathrm{~L}$ & \multirow[t]{2}{*}{80} \\
\hline & & 1 & 0 & 0 & 0 & 0 & 0 & 0 & 0 & \\
\hline \multirow{2}{*}{\multicolumn{2}{|c|}{$\begin{array}{l}\text { ROW \#2: RELAY WORD } \\
\text { BINARY REPRESENTATION }\end{array}$}} & $51 \mathrm{NT}$ & $67 \mathrm{N1}$ & $67 \mathrm{~N} 2$ & $67 \mathrm{~N} 3$ & $51 \mathrm{NP}$ & $\mathrm{Z1P}$ & $\mathrm{Z2P}$ & Z3P & \multirow[t]{2}{*}{$C 4$} \\
\hline & & 1 & 1 & 0 & 0 & 0 & 1 & 0 & 0 & \\
\hline \multirow{2}{*}{\multicolumn{2}{|c|}{$\begin{array}{l}\text { ROW \#3: RELAY WORD } \\
\text { BINARY REPRESENTATION }\end{array}$}} & $\mathrm{Z2PT}$ & Z3PT & OSB & $3 P 50$ & $50 \mathrm{MF}$ & $\mathrm{RI}$ & $\mathrm{RC}$ & DF & \multirow[t]{2}{*}{$C 8$} \\
\hline & & 1 & 1 & 0 & 0 & 1 & 0 & 0 & 0 & \\
\hline \multirow{2}{*}{\multicolumn{2}{|c|}{$\begin{array}{l}\text { ROW \#4: RELAY WORD } \\
\text { BINARY REPRESENTATION }\end{array}$}} & ALRM & TRIP & TC & DT & 52BT & $23 x$ & Z2GT & Z3GT & \multirow[t]{2}{*}{21} \\
\hline & & 0 & 0 & 1 & 0 & 0 & 0 & 0 & 1 & \\
\hline
\end{tabular}

\begin{tabular}{|c|c|}
\hline BINARY & HEXIDECIMAL \\
\hline 0000 & 0 \\
0001 & 1 \\
0010 & 2 \\
0011 & 3 \\
0100 & 4 \\
0101 & 5 \\
0110 & 6 \\
0111 & 7 \\
1000 & 8 \\
1001 & 9 \\
1010 & A \\
1011 & B \\
1100 & C \\
1101 & D \\
1110 & E \\
1111 & F \\
\hline
\end{tabular}

MASK SETTINGS

\begin{tabular}{|c|c|c|c|c|c|c|c|c|c|}
\hline MTU & MPT & MTB & MTO & MA1 & MA2 & MA3 & MA4 & MRI & MRC \\
\hline 80 & 00 & 00 & C0 & 80 & 40 & 00 & 00 & 00 & 00 \\
\hline C4 & 00 & 00 & 66 & C4 & 22 & 00 & 00 & 00 & 00 \\
\hline C8 & 00 & 00 & 00 & $C 8$ & 00 & 00 & 00 & 00 & 00 \\
\hline 20 & 00 & 00 & 00 & 20 & 00 & 00 & 00 & 00 & 00 \\
\hline
\end{tabular}

\section{MASK SETTING NOTES}

1. MTU is set to trip the A- 386 locally and not actuate an integrated transfer trip.

2. MTO is set to for trip onto fault protection. This mask will trip A-386 locally and will not actuate an integrated transfer trip.

3. MT1 is set for direct underreach transfer trip.

4. MT2 is set for permissive overreach transfer trip.

5. MPT, MTB, MA3, MA4, MRI, and MRC are not used and are to be masked to 00. 


\begin{tabular}{|c|c|c|c|c|c|}
\hline Description & \multicolumn{2}{|c|}{$\begin{array}{l}\text { POSITIVE SEQUENCE } \\
\text { IMPEDANCE }\end{array}$} & \multicolumn{2}{|c|}{$\begin{array}{l}\text { ZERO SEQUENCE } \\
\text { IMPEDANCE }\end{array}$} & $\begin{array}{c}\text { LINE } \\
\text { LENGTH* }\end{array}$ \\
\hline $\begin{array}{c}\text { Range } \\
\text { Abbrev. }\end{array}$ & $---\frac{0-9999 \Omega}{R 1}$ & PRIMARY & $--\frac{0-9999 \Omega}{\text { RO }}$ & PRIMARY & $0.1-999$ (MILES) \\
\hline SETTING & .88 & 8.54 & 6.90 & 18.42 & 9.94 \\
\hline Description & CT RATIO & PT RATIO & $\begin{array}{l}\text { MAX TORQUE } \\
\text { ANGLE }\end{array}$ & $\begin{array}{c}\text { ENABLE FAULT } \\
\text { LOCATOR }\end{array}$ & \\
\hline Range - & - $-\frac{1-5000: 1}{\mathrm{CTR}}$ & PTR & $-47 E-90 E-$ & $-\cdots \frac{(Y \text { or } N)}{\text { LOCAT }}$ & \\
\hline SETTING & 160 & 2000 & 84.6 & $\mathbf{Y}$ & \\
\hline Description & $\begin{array}{l}\text { RECL. OPEN } \\
\text { INT } 1 \\
\end{array}$ & $\begin{array}{c}\text { RECL OPEN } \\
\text { INT } 2 \\
\end{array}$ & $\begin{array}{l}\text { RECL OPEN } \\
\text { INT } 3\end{array}$ & $\begin{array}{c}\text { RECL RESET } \\
\text { TIME }\end{array}$ & \\
\hline $\begin{array}{l}\text { Range } \\
\text { Abbrev. } \\
\end{array}$ & $\begin{array}{c}0-10,000 \text { cycles } \\
(1 / 4 \text { cycle steps }) \\
79011\end{array}$ & $\begin{array}{c}0-10,000 \text { cycles } \\
(1 / 4 \text { cycle steps }) \\
79012\end{array}$ & $\begin{array}{l}0-10,000 \text { cycles } \\
(1 / 4 \text { cycle steps }) \\
79013\end{array}$ & $\begin{array}{c}60-8,000 \text { cycles } \\
(1 / 4 \text { cycle steps }) \\
79 R S\end{array}$ & \\
\hline SETTING & 0 & 0 & 0 & 60 & \\
\hline Description & ZONE 1 REACH & ZONE 2 REACH & ZONE 3 REACH & & \\
\hline $\begin{array}{l}\text { Range } \\
\text { Abbrev. }\end{array}$ & $\begin{array}{c}0-2000 \% \text { of } \mathrm{LL} \\
(0.125-64 \Omega \text { SEC) } \\
21 \%\end{array}$ & $\begin{array}{c}0-3200 \% \text { of } \mathrm{LL} \\
(0.125-64 \Omega \text { SEC) } \\
Z 22 \%\end{array}$ & $\begin{array}{c}0-3200 \% \text { of } \pm L \\
(0.125-64 \Omega \text { SEC) } \\
Z 3 \%\end{array}$ & - & \\
\hline SETTING & 85 & 125 & 335 & & \\
\hline Description & $\begin{array}{l}\text { ZONE } 2 \phi \phi \& 3 \phi \\
\text { SHORT TIMER }\end{array}$ & $\begin{array}{l}\text { ZONE } 2 \phi \phi \& 3 \phi \\
\text { TIME-STEP } \\
\text { BACKUP TIMER }\end{array}$ & $\begin{array}{c}\text { ZONE } 3 \phi \phi \& 3 \phi \\
\text { TIME-STEP } \\
\text { BACKUP TIMER }\end{array}$ & & \\
\hline $\begin{array}{l}\text { Range } \\
\text { Abbrev. }\end{array}$ & $\begin{array}{c}0-60 \text { cycles } \\
(1 / 4 \text { cycle steps) } \\
\text { Z25P }\end{array}$ & $\begin{array}{c}0-2000 \text { cycles } \\
(1 / 4 \text { cycle steps }) \\
\text { Z2DP }\end{array}$ & $\begin{array}{c}0-2000 \text { cycles } \\
(1 / 4 \text { cycle steps }) \\
\text { Z3DP }\end{array}$ & - & \\
\hline SETTING & 0 & 24 & 42 & & \\
\hline Description & $\begin{array}{l}\text { \$O/C LOW } \\
\text { SET PICKUP }\end{array}$ & $\begin{array}{l}\phi O / C \text { MEDIUM } \\
\text { SET PICKUP }\end{array}$ & $\begin{array}{l}\text { QO/C LOP } \\
\text { DELAY (loss of } \\
\text { potential) }\end{array}$ & $\begin{array}{l}\text { \$OIC HIGH } \\
\text { SET PICKUP }\end{array}$ & \\
\hline $\begin{array}{l}\text { Range } \\
\text { Abbrev. }\end{array}$ & $\begin{array}{c}(0.5-40 \mathrm{~A} \text { SEC }) \\
0.25-50,000 \mathrm{~A} \text { PRI } \\
50 \mathrm{~L}\end{array}$ & $\begin{array}{c}(0.5-40 \mathrm{~A} \text { SEC) } \\
0.25-50,000 \mathrm{~A} \text { PRI } \\
50 \mathrm{M}\end{array}$ & $\begin{array}{c}0-60 \text { cycles } \\
(1 / 4 \text { cycle steps }) \\
50 \text { mF }\end{array}$ & $\begin{array}{c}\text { (0.5-80A SEC) } \\
0.25-50,000 \mathrm{~A} \text { PRI } \\
50 \mathrm{H}\end{array}$ & \\
\hline SETTING & $\begin{array}{r}500 \\
\end{array}$ & 2228 & 60 & 12,000 & \\
\hline Description & $\begin{array}{l}\text { GND TIME O/C } \\
\text { PICKUP }\end{array}$ & $\begin{array}{l}\text { GND TIME O/C } \\
\text { TIMED DIAL }\end{array}$ & $\begin{array}{l}\text { GND TIME O/C } \\
\text { CURVE SHAPE }\end{array}$ & $\begin{array}{l}\text { GND TIME O/C } \\
\text { TORQ. } \\
\text { CONTROL }\end{array}$ & \\
\hline $\begin{array}{l}\text { Range } \\
\text { Abbrev. }\end{array}$ & $\begin{array}{c}(0.25-6.3 \mathrm{~A} \text { SEC) } \\
0.25-50,000 \mathrm{APRI} \\
51 \mathrm{NP}\end{array}$ & $\begin{array}{c}0.5-15 A \text { SEC } \\
(0.01 \text { STEPS }) \\
51 N T D \\
\end{array}$ & $\begin{array}{l}1,2,3, \text { or } 4 \\
51 \mathrm{NC}\end{array}$ & $\begin{array}{c}(\mathrm{Y} \text { or } N) \\
51 \mathrm{NTC}\end{array}$ & \\
\hline SETTING & 100 & 4 & 3 & $\mathbf{Y}$ & \\
\hline
\end{tabular}




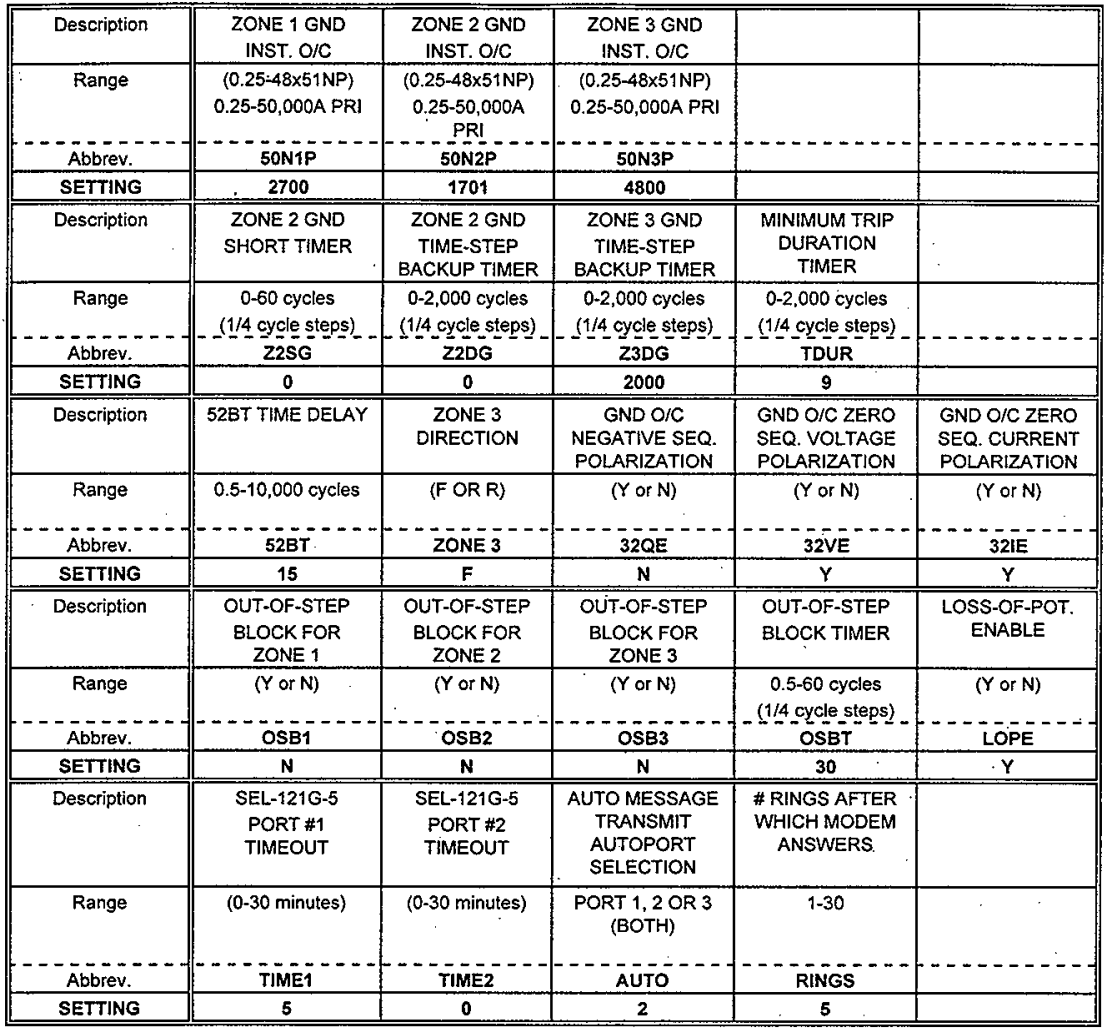

\section{Comments}




\section{SUBSTATION A2, A4, AND A9 SEL 121G-5 RELAY SETTINGS}

ALL REMAINING SEL RELAYS LOCATED AT SUBSTATIONS A2, A4 AND A9 ARE TO HAVE THEIR MASK SETTINGS SET TO 00 , AND DE-ENERGIZED. THE LINE PROTECTION RELAYS AT THESE SUBSTATIONS HAS BEEN RETIRED IN PLACE.

SEL 121G-5 relays retired in place: OCB A322, A326, A342, A346, A379, A388, A392, and A396. 


\section{RFL STATION CONFIGURATION VERIFICATION}

Circuit card jumpers (strapping) must be established to adapt the station to the specific requirements of the installation. This document identifies the jumper configuration for the RFL stations. The RFL relay will be used to accomplish two applications; direct underreach and permissive overreach transfer tripping of transmission line relaying. This dual purpose application requires the configuration of the digital and redundant digital logic cards to be different.

The main digital logic card will be configured for the Permissive Relay Trip (PRT) function; permissive overreach transfer trip. When a choice between system dependability and security is provided, dependability will be chosen.

The redundant digital logic card will be configured for the Direct Relay Trip (DRT) function; direct underreach transfer trip. When a choice between system dependability and security is provided, security will be chosen.

The following pages contain a table for each circuit card and the position of each jumper. The last table contains a listing of the frequency and tone levels for each station.

\section{REFERENCES}

VI 19188 - RFL Dowtey Model 6750 ITTS Instruction Manual.

\section{DEFINITIONS}

Dependability - That facet of reliability that relates to the degree of certainty that a relay or relay system will operate correctly.

Security - That facet of reliability that relates to the degree of certainty that a relay or relay system will not operate incorrectly. 
MAIN ANALOG LOGIC CARD (Card 67A LOGIC-63)

\begin{tabular}{|c|c|c|c|}
\hline Jumper & Key Words & $\begin{array}{c}\text { DYNCORP } \\
\text { Position }\end{array}$ & Function \\
\hline 1 & AM Noise Control & A & $\begin{array}{l}\text { Position A - AM Noise detection will not cause blocking in the event of } \\
\text { a steady state difference in subchannel levels. } \\
\text { Position B - AM Noise detection will cause blocking in the event of a } \\
\text { steady state difference in subchannel levels. } \\
\text { Position A is selected because system dependability is } \\
\text { increased. }\end{array}$ \\
\hline 2 & FM Noise Control & A & $\begin{array}{l}\text { Position A - FM Noise detection will not cause blocking in the event of } \\
\text { a steady state difference in subchannel levels. } \\
\text { Position B - FM Noise detection will cause blocking in the event of a } \\
\text { steady state difference in subchannel levels. } \\
\text { Position A is selected because system dependability is } \\
\text { increased. }\end{array}$ \\
\hline 3 & $\begin{array}{l}\text { High Level Window } \\
\text { Detector }\end{array}$ & A & $\begin{array}{l}\text { Position A - When either subchannel exceeds the predetermined } \\
\text { limits, a out-of-limits indication will be generated. } \\
\text { Position B - When subchannel B exceeds the predetermined limits, a } \\
\text { out-of-limits indication will be generated. } \\
\text { Position C - When subchannel A exceeds the predetermined limits, a } \\
\text { out-of-limits indication will be generated. } \\
\text { Position A is selected because system dependability is } \\
\text { increased. }\end{array}$ \\
\hline 4 & $\begin{array}{c}\text { Low Level Window } \\
\text { Detector }\end{array}$ & A & $\begin{array}{l}\text { Position A - An out of limits indication will be generated when either } \\
\text { subchannel exceeds the predetermined limit. } \\
\text { Position B - An out of limits indication will be generated when } \\
\text { subchannel B exceeds the predetermined limit. } \\
\text { Position C - When subchannel A exceeds the predetermined limits, a } \\
\text { out-of-limits indication will be generated. } \\
\text { Position A is selected because system dependability is } \\
\text { increased. (BPA uses different positions for jumpers } 3 \text { and 4, } \\
\text { due to past settings on like RFL units and not due to } \\
\text { dependability or security requirements). }\end{array}$ \\
\hline 5 & Guard Detection & A & $\begin{array}{l}\text { Position A - A guard signal can be detected and indicated during } \\
\text { low level conditions. } \\
\text { Position B - A guard signal detection will be prevented during } \\
\text { low-level conditions. } \\
\text { Position A is selected because system dependability is } \\
\text { increased. }\end{array}$ \\
\hline
\end{tabular}


MAIN (DIGITAL) LOGIC CARD JUMPERS (Card 67A LOGIC-63)

\begin{tabular}{|c|c|c|c|}
\hline Jumper & Key Words & $\begin{array}{c}\text { DYNCORP } \\
\text { Position } \\
\end{array}$ & Function \\
\hline 1 & $\begin{array}{l}\text { Jumpers } 1 \text { through } \\
4 \text { determine } \\
\text { whether trip and/or } \\
\text { guard are required } \\
\text { on each } \\
\text { subchannel. }\end{array}$ & A & $\begin{array}{l}\text { Jumpers } 1 \text { through } 4 \text { determine whether trip and/or guard are required } \\
\text { on each subchannel. Jumper } 1 \text { controls trip on subchannel } A \text {, Jumper } \\
2 \text { controls trip on subchannel } B_{1} \text {. Jumper } 3 \text { controls guard on } \\
\text { subchannel } A_{1} \text { and Jumper } 4 \text { controls guard on subchannel } B \text {. If one } \\
\text { of these jumpers is placed in position } A \text {, the signal it controls is } \\
\text { required; the signal is not required if the jumper is placed in position } \\
\text { B. } \\
\text { One subchannel is used to establish separate tones for each } \\
\text { subchannel. Notice that the jumpers on the redundant digital } \\
\text { logic card are different. } \\
\text { Select jumpers such that only one subchannel for trip or guard. } \\
\text { Therefore, Jumper } 2 \text { is placed in position B and Jumper } 4 \text { is } \\
\text { placed in position } B \text {. }\end{array}$ \\
\hline 2 & & B & \\
\hline 3 & & $\mathrm{~A}$ & \\
\hline 4 & & B & \\
\hline 5 & Timer Control & A & $\begin{array}{l}\text { Position A - Timers for guard-before-trip and trip-after-guard are } \\
\text { enabled. } \\
\text { Position B - Timers for for guard-before-trip and trip-after-guard are } \\
\text { disabled. } \\
\text { Use the Main Digital Logic Card as the PRT card. Therefore the } \\
\text { guard-before-trip must be enabled per telephone conversation } \\
\text { with Bob Perkins of RFL Dowty. }\end{array}$ \\
\hline 6 & Guard Control. & A & $\begin{array}{l}\text { Position A - A guard signal is required to be present on both } \\
\text { suchannels unless Jumper } 3 \text { or } 4 \text { are set to position B. } \\
\text { Position B - A guard signal is required to be present on only one } \\
\text { subchannel. } \\
\text { Selection is irrelevant because Jumper } 3 \text { has been set to } \\
\text { position B. Therefore, select the defautt position A (defautt). A } \\
\text { guard signal need only to be present on one subchannel to set } \\
\text { the criteria for a guard. }\end{array}$ \\
\hline 7 & Pre-Trip Control & A & $\begin{array}{l}\text { Position A - A valid guard signal is required to precede only the first } \\
\text { Prip. } \\
\text { Position B - A valid guard signal is required to precede each trip. } \\
\text { Position A is selected because it is not desirable to have a time } \\
\text { delay ( } 300 \mathrm{~ms} 6 \text { guard before trip timer) that may interfer with the } \\
\text { autoreclosing system. A valid guard signal will be required to } \\
\text { precede only the first trip. }\end{array}$ \\
\hline
\end{tabular}


MAIN (DIGITAL) LOGIC CARD JUMPERS (Card 67A LOGIC-63)

\begin{tabular}{|c|c|c|c|}
\hline Jumper & Key Words & $\begin{array}{c}\text { DYNCORP } \\
\text { Position }\end{array}$ & Function \\
\hline 8 & $\begin{array}{c}\text { Noise Detection } \\
\text { Control }\end{array}$ & A & $\begin{array}{l}\text { Position A - A valid guard signal is required to enable noise detection } \\
\text { for the block timer; a valid trip will override. } \\
\text { Position B - A valid guard signal is not required for noise detection. } \\
\text { Position A is selected because system dependability is } \\
\text { increased. A valid guard signal enables noise detection for the } \\
\text { block timer; a valid trip will override. Noise or low signal will } \\
\text { block the trip output, but a valid trip signal will override the } \\
\text { noise detector. }\end{array}$ \\
\hline 9 & $\begin{array}{c}\text { Trip-Hold Timer } \\
\text { Control } \\
.\end{array}$ & A & $\begin{array}{l}\text { Position A - A guard signal will override of the trip-hold timer. } \\
\text { Position B - The trip-hold timer will be allowed to time out before the } \\
\text { return of a guard signal can be acknowledged. This position is } \\
\text { selected in systems using a flasher. } \\
\text { The installed system does not use a flasher, therefore select } \\
\text { Position A. Guard signal will override the trip-hold timer. When } \\
\text { a return from trip to guard is recognized, the trip-hold timer will } \\
\text { cease to hold the trip output. }\end{array}$ \\
\hline 10 & $\begin{array}{l}\text { Permissive Trip } \\
\text { Control }\end{array}$ & A & $\begin{array}{l}\text { Position A - Use this position when any application is used except } \\
\text { permissive trip. } \\
\text { Position B - Use this position only for permissive trip applications. } \\
\text { Select Position A because the direct-transfer-trip logic card will } \\
\text { have an application that includes other schemes than just } \\
\text { permissive transfer trip applications. }\end{array}$ \\
\hline 11 & $\begin{array}{c}\text { Bipolar Noise } \\
\text { Detection Control }\end{array}$ & B & $\begin{array}{l}\text { Position A - Enable the bipolar noise detector. } \\
\text { Position B - Disable the bipolar noise detector. } \\
\text { Select Position B to disable the bipolar noise detector. This is a } \\
\text { recommended setting for the permissive-transfer-trip logic card } \\
\text { of permissive-transfer-trip systems. }\end{array}$ \\
\hline 12 & Unblocking Control & A & $\begin{array}{l}\text { Position A - Use this positoin for any application except unblocking. } \\
\text { Position B - Use this position only for unblocking applications, where } \\
\text { a loss of guard signal will provide a trip. } \\
\text { Select Position } A_{\text {, because our application is a scheme other }} \\
\text { than blocking use. }\end{array}$ \\
\hline 13 & $\begin{array}{l}\text { Direct-Transfer } \\
\text { Trip Control }\end{array}$ & B & $\begin{array}{l}\text { Position A - Use this position to cancel out the permissive-transfer trip } \\
\text { output when a direct-transfer trip occurs. } \\
\text { Position B - Use this position to cause a trip when both the direct-trip } \\
\text { output and permissive-trip output occurs. } \\
\text { Select Position B so that a direct-trip and permissive-trip output } \\
\text { will trip when a direct-transfer trip occurs. }\end{array}$ \\
\hline
\end{tabular}


REDUNDANT DIGITAL LOGIC CARD JUMPERS (Card 67A LOGIC-64)

\begin{tabular}{|c|c|c|c|}
\hline Jumper & Key Words & $\begin{array}{c}\text { DYNCORP } \\
\text { Position }\end{array}$ & Function \\
\hline 1 & \multirow[t]{4}{*}{$\begin{array}{l}\text { Jumpers } 1 \text { through } \\
4 \text { determine } \\
\text { whether trip and/or } \\
\text { guard are required } \\
\text { on each } \\
\text { subchannel. }\end{array}$} & $B$ & \multirow[t]{4}{*}{$\begin{array}{l}\text { Jumpers } 1 \text { through } 4 \text { determine whether trip and/or guard are required } \\
\text { on each subchannel. Jumper } 1 \text { controls trip on subchannel } A \text {, Jumper } \\
2 \text { controls trip on subchannel } B \text {, Jumper } 3 \text { controls guard on } \\
\text { subchannel } A_{1} \text { and Jumper } 4 \text { controls guard on subchannel } B \text {. If one } \\
\text { of these jumpers is placed in position } A \text {, the signal it controls is } \\
\text { required; the signal is not required if the jumper is placed in position } \\
\text { B. } \\
\text { One subchannel is used to establish separate tones for each } \\
\text { subchannel. Notice that the jumpers on the main digital logic } \\
\text { card are different. } \\
\text { Select jumpers such that only one subchannel for trip or guard. } \\
\text { Therefore, Jumper } 2 \text { is placed in position B and Jumper } 4 \text { is } \\
\text { placed in position B. }\end{array}$} \\
\hline 2 & & A & \\
\hline 3 & & B & \\
\hline 4 & & $\mathrm{~A}$ & \\
\hline 5 & Timer Control & B. & $\begin{array}{l}\text { Position A - Timers for guard-before-trip and trip-after-guard are } \\
\text { enabled. } \\
\text { Position B - Timers for for guard-before-trip and trip-after-guard are } \\
\text { disabled. } \\
\text { Use the Redundant Digital Logic Card as the DRT card. } \\
\text { Therefore the guard-before-trip must not be enabled per } \\
\text { telephone conversation with Bob Perkins of RFL Dowty. Select } \\
\text { Position B. }\end{array}$ \\
\hline 6 & Guard Control & A & $\begin{array}{l}\text { Position A - A guard signal is required to be present on both } \\
\text { suchannels unless Jumper } 3 \text { or } 4 \text { are set to position B. } \\
\text { Position B - A guard signal is required to be present on only one } \\
\text { subchannel. } \\
\text { Selection is irrelevant because Jumper } 3 \text { has been set to } \\
\text { position B. Therefore, select the default position, position A. A } \\
\text { guard signal need only to be present on one subchannel to set } \\
\text { the criteria for a guard. }\end{array}$ \\
\hline 7 & Pre-Trip Control & A & $\begin{array}{l}\text { Position A - A valid guard signal is required to precede only the first } \\
\text { trip. } \\
\text { Position B - A valid guard signal is required to precede each trip. } \\
\text { Position A is selected because it is not desirable to have a time delay } \\
\text { (300ms } 6 \text { guard before trip timer) that may interfer with the } \\
\text { autoreclosing system. A valid guard signal will be required to precede } \\
\text { only the first trip. }\end{array}$ \\
\hline
\end{tabular}


REDUNDANT DIGITAL LOGIC CARD JUMPERS (Card 67A LOGIC-64)

\begin{tabular}{|c|c|c|c|}
\hline Jumper & Key Words & $\begin{array}{c}\text { DYNCORP } \\
\text { Position }\end{array}$ & Function \\
\hline 8 & $\begin{array}{l}\text { Noise Detection } \\
\text { Control }\end{array}$ & B & $\begin{array}{l}\text { Position A - A valid guard signal is required to enable noise detection } \\
\text { for the block timer; a valid trip will override. } \\
\text { Position B - A valid guard signal is not required for noise detection. } \\
\text { Position B is selected because security is increased. Because } \\
\text { this is the card utilizing the DRT, security is preferred over } \\
\text { dependability. }\end{array}$ \\
\hline 9 & $\begin{array}{l}\text { Trip-Hold Timer } \\
\text { Control }\end{array}$ & A & $\begin{array}{l}\text { Position A - A guard signal will override of the trip-hold timer. } \\
\text { Position B - The trip-hold timer will be allowed to time out before the } \\
\text { return of a guard signal can be acknowledged. This position is } \\
\text { selected in systems using a flasher. } \\
\text { The installed system does not use a flasher, therefore select } \\
\text { Position A. Guard signal will override the trip-hold timer. When } \\
\text { a return from trip to guard id recognized, the trip-hold timer will } \\
\text { cease to hold the trip output. }\end{array}$ \\
\hline 10 & $\begin{array}{l}\text { Permissive Trip } \\
\text { Control }\end{array}$ & A & $\begin{array}{l}\text { Position A - Use this position when any application is used except } \\
\text { permissive trip. } \\
\text { Position B - Use this position only for permissive trip applications. } \\
\text { Select Position A because the direct-transfer-trip logic card will } \\
\text { have an application that inc/udes other schemes than just } \\
\text { permissive transfer trip applications. }\end{array}$ \\
\hline 11 & $\begin{array}{c}\text { Bipolar Noise } \\
\text { Detection Control }\end{array}$ & B & $\begin{array}{l}\text { Position A - Enable the bipolar noise detector. } \\
\text { Position B - Disable the bipolar noise detector. } \\
\text { Select Position B to disable the bipolar noise detector. This is a } \\
\text { recommended setting for the permissive-transfer-trip logic card } \\
\text { of permissive-transfer-trip systems. }\end{array}$ \\
\hline 12 & Unblocking Control & A & $\begin{array}{l}\text { Position A - Use this positoin for any application except unblocking. } \\
\text { Position B - Use this position only for unblocking applications, where } \\
\text { a loss of guard signal will provide a trip. } \\
\text { Select Position A, because our application is a scheme other } \\
\text { than blocking use. }\end{array}$ \\
\hline 13 & $\begin{array}{l}\text { Direct-Transfer } \\
\text { Trip Control }\end{array}$ & $B$ & $\begin{array}{l}\text { Position A-Use this position to cancel out the permissive-transfer trip } \\
\text { output when a direct-transfer trip occurs. } \\
\text { Position B - Use this position to cause a trip when both the direct-trip } \\
\text { output and permissive-trip output occurs. } \\
\text { Select Position B so that a direct-trip and permissive-trip output } \\
\text { will trip when a direct-transfer trip occurs. }\end{array}$ \\
\hline
\end{tabular}


TRANSMITTER CARD JUMPERS (Card 67 TRANS)

\begin{tabular}{|c|c|c|c|c|c|c|}
\hline $\begin{array}{l}\text { Jumper } \\
\text { Position }\end{array}$ & Key Words & $\begin{array}{l}\text { DYNCORP } \\
\text { Position }\end{array}$ & \multicolumn{4}{|c|}{ Function } \\
\hline B & Subchannel A & B & \multicolumn{4}{|c|}{ See below for function description. } \\
\hline$F$ & Subchannel B & $F$ & & & & \\
\hline \multirow[t]{2}{*}{$\begin{array}{c}\text { Channel Spacing } \\
(\mathrm{Hz})\end{array}$} & \multirow[t]{2}{*}{$\begin{array}{l}\text { Frequency } \\
\text { Shift }(\mathrm{Hz})\end{array}$} & \multicolumn{5}{|c|}{ Operating Frequencies $(\mathrm{Hz})$} \\
\hline & & Subch & nel & Center & Trip & Guard \\
\hline \multirow[t]{2}{*}{680} & \multirow[t]{2}{*}{ \pm 150} & \multicolumn{2}{|c|}{ A } & 1615 & 1465 & 1765 \\
\hline & & \multicolumn{2}{|c|}{$\mathrm{B}$} & 2295 & 2445 & 2145 \\
\hline
\end{tabular}

INTERFACE CARD JUMPERS (Card 67A Inter-1)

\begin{tabular}{|c|c|c|c|}
\hline Jumper & Key Words & $\begin{array}{l}\text { DYNCORP } \\
\text { Position }\end{array}$ & Function \\
\hline A & \multirow[t]{5}{*}{$\begin{array}{l}\text { Transmit Level } \\
\text { Configuration } \\
\text { Selection }\end{array}$} & $-10 \mathrm{DBM}$ & \multirow[t]{5}{*}{$\begin{array}{l}\text { Jumpers A through } E \text { select the maximum transmit output level and } \\
\text { determine whether two-wire or four-wire connections are to be made } \\
\text { to the communication circuit. } \\
\text { The RFL system is a four wire operation with a maximum output } \\
\text { level of }-10 \mathrm{dBm} \text {. }\end{array}$} \\
\hline$B$ & & $4 W$ & \\
\hline c & & $4 W$ & \\
\hline$D$ & & OUT & \\
\hline$E$ & & OUT & \\
\hline$F$ & $\begin{array}{c}\text { Signal } \\
\text { Multiplexing }\end{array}$ & DIR & $\begin{array}{l}\text { Jumper } F \text { is the receive circuit. Only one transmitter or receiver } \\
\text { can be connected to the line. } \\
\text { Jumper } F \text { is selected in the DIR position because only one RFL } \\
6750 \text { will be connected to the line. }\end{array}$ \\
\hline $\mathrm{G}$ & $\begin{array}{l}\text { Single/Dual Trip } \\
\text { Selection }\end{array}$ & ST & $\begin{array}{l}\text { Jumpers } G \text { and } H \text { set the interface card for single trip position (ST) or } \\
\text { dual trip (DT). } \\
\text { Select position ST for each jumper for proper operation. }\end{array}$ \\
\hline $\mathrm{H}$ & & ST & \\
\hline $\mathbf{K}$ & Signal Multiplexing & IN & $\begin{array}{l}\text { Jumper } K \text { is the transmit circuit. Only one transmitter or receiver can } \\
\text { be connected to the line. } \\
\text { Jumper } K \text { is selected in the IN position because only one RFL } \\
6750 \text { will be connected to the fine. }\end{array}$ \\
\hline
\end{tabular}


RECEIVER CARD JUMPERS (Card 67B REC LO)

\begin{tabular}{|c|c|c|l|}
\hline Jumper & Key Words & $\begin{array}{c}\text { DYNCORP } \\
\text { Position }\end{array}$ & \multicolumn{1}{|c|}{ Function } \\
\hline 1 & Trip Boost & $\mathrm{F}$ & Jumper must be in position F (fast) when trip boost is not being used. \\
& $\begin{array}{l}\text { Because we are not using trip boost, place the Jumper in } \\
\text { Position } F .\end{array}$ \\
\hline
\end{tabular}

RECEIVER CARD JUMPERS (Card 67B REC H)

\begin{tabular}{|c|c|c|c|}
\hline Jumper & Key Words & $\begin{array}{c}\text { DYNCORP } \\
\text { Position }\end{array}$ & Function \\
\hline 1 & Trip Boost & $F$ & Jumper must be in position F (fast) when trip boost is not being used. \\
\hline
\end{tabular}

FSIAM DETECTOR CARD JUMPERS (Card 67FS/AM)

\begin{tabular}{|c|c|c|}
\hline Jumper & $\begin{array}{c}\text { DYNCORP } \\
\text { Position }\end{array}$ & Function \\
\hline A & USED & $\begin{array}{c}\text { These jumpers are factory soldered connection points: Jumpers are installed to route } \\
\text { input signals to the four detector circuits on this card. For most applications, jumpers } \\
\text { will be installed in positions A, D, F, and } G .\end{array}$ \\
\hline B & NOT USED & \\
\hline C & NOT USED & \\
\hline$D$ & USED & \\
\hline$E$ & NOT USED & \\
\hline F & USED \\
\hline$G$ & USED & \\
\hline$H$ & NOT USED & \\
\hline
\end{tabular}


SIGNAL LEVEL INDICATOR/MONITOR CARD JUMPERS (Card 67A LEVEL IND)

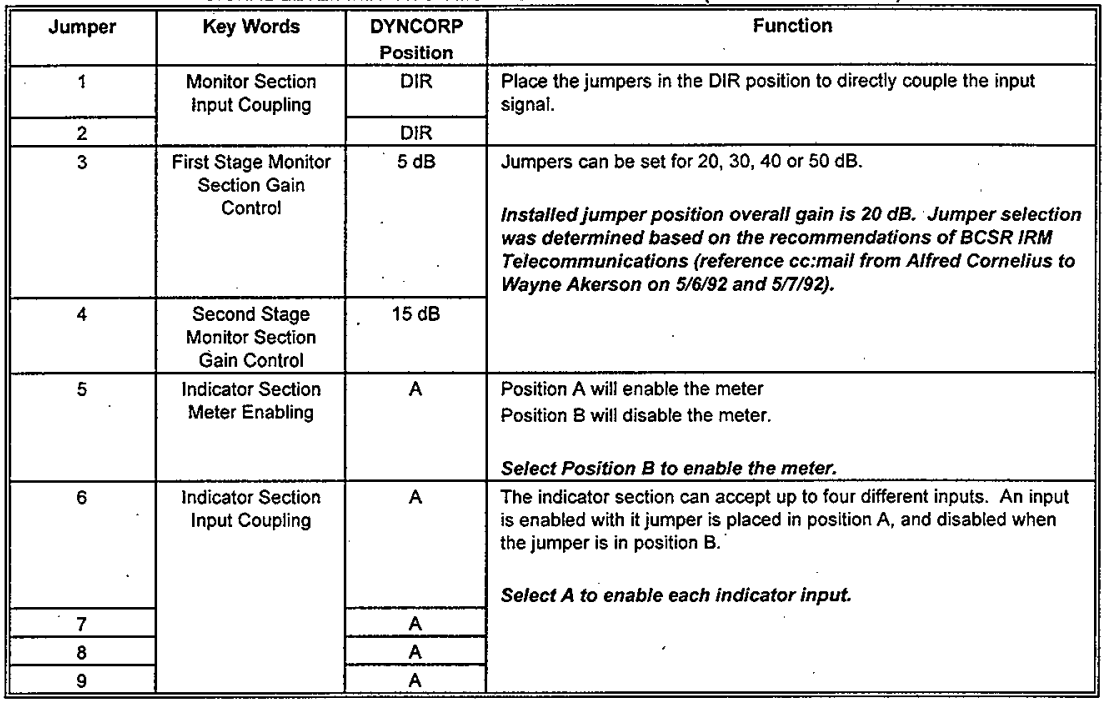


BREAKER: $A-372$

Main Analog Logic Card - 67A LOGIC-63

\begin{tabular}{|c|c|c|c|c|c|}
\hline JUMPER & 1 & 2 & 3 & 4 & 5 \\
\hline POSITION & A & A & A & A & A \\
\hline
\end{tabular}

Main Digital Logic Card - 67A LOGIC-63

\begin{tabular}{|c|c|c|c|c|c|c|c|c|c|c|c|c|c|}
\hline JUMPER & 1 & 2 & 3 & 4 & 5 & 6 & 7 & 8 & 9 & 10 & 11 & 12 & 13 \\
\hline POSITION & $\mathrm{A}$ & $\mathrm{B}$ & $\mathrm{A}$ & $\mathrm{B}$ & $\mathrm{A}$ & $\mathrm{A}$ & $\mathrm{A}$ & $\mathrm{A}$ & $\mathrm{A}$ & $\mathrm{A}$ & $\mathrm{B}$ & $\mathrm{A}$ & $\mathrm{B}$ \\
\hline
\end{tabular}

Redundant Digital Logic Card - 67A LOGIC-64

\begin{tabular}{|c|c|c|c|c|c|c|c|c|c|c|c|c|c|}
\hline JUMPER & 1 & 2 & 3 & 4 & 5 & 6 & 7 & 8 & 9 & 10 & 11 & 12 & 13 \\
\hline POSITION & B & A & B & A & B & A & A & B & A & A & B & A & B \\
\hline
\end{tabular}

Transmitter Card - 67 TRANS

\begin{tabular}{|c|c|c|}
\hline JUMPER & Ch. A & Ch. B \\
\hline POSITION & B & F \\
\hline
\end{tabular}

Interface Card - 67A Inter-1

\begin{tabular}{|c|c|c|c|c|c|c|c|c|c|}
\hline JUMPER & A & B & C & D & E & F & G & H & K \\
\hline POSITION & $-10 \mathrm{dBm}$ & $4 \mathrm{~W}$ & $4 \mathrm{~W}$ & OUT & OUT & DIR & ST & ST & IN \\
\hline
\end{tabular}

Low Receiver Card - 67B REC LO

JUMPER \begin{tabular}{|l|l|}
\hline POSITION & F \\
\hline
\end{tabular}

High Receiver Card - 67B REC HII JUMPER \begin{tabular}{|l|l|}
\hline POSITION & F \\
\hline
\end{tabular}

FS/AM Detector Card - 67FS/AM

\begin{tabular}{|c|c|c|c|c|c|c|c|c|}
\hline JUMPER & A & B & C & D & E & F & G & $H$ \\
\hline POSITION & USED & $\begin{array}{c}\text { NOT } \\
\text { USED }\end{array}$ & $\begin{array}{c}\text { NOT } \\
\text { USED }\end{array}$ & USED & $\begin{array}{c}\text { NOT } \\
\text { USED }\end{array}$ & USED & USED & $\begin{array}{c}\text { NOT } \\
\text { USED }\end{array}$ \\
\hline
\end{tabular}

Signal Level Card - 67A LEVEL IND

\begin{tabular}{|c|c|c|c|c|c|c|c|c|c|}
\hline JUMPER & 1 & 2 & 3 & 4 & 5 & 6 & 7 & 8 & 9 \\
\hline POSITION & DIR & DIR & $5 \mathrm{dBm}$ & $15 \mathrm{dBm}$ & $\mathrm{A}$ & $\mathrm{A}$ & $\mathrm{A}$ & $\mathrm{A}$ & $\mathrm{A}$ \\
\hline
\end{tabular}


BREAKER: A-376

Main Analog Logic Card - 67A LOGIC-63

\begin{tabular}{|c|c|c|c|c|c|}
\hline JUMPER & 1 & 2 & 3 & 4 & 5 \\
\hline POSITION & $\mathrm{A}$ & $\mathrm{A}$ & $\mathrm{A}$ & $\mathrm{A}$ & $\mathrm{A}$ \\
\hline
\end{tabular}

Main Digital Logic Card - 67A LOGIC-63

\begin{tabular}{|c|c|c|c|c|c|c|c|c|c|c|c|c|c|}
\hline JUMPER & 1 & 2 & 3 & 4 & 5 & 6 & 7 & 8 & 9 & 10 & 11 & 12 & 13 \\
\hline POSITION & A & $\mathrm{B}$ & $\mathrm{A}$ & $\mathrm{B}$ & A & A & A & $\mathrm{A}$ & A & $\mathrm{A}$ & B & A & $\mathrm{B}$ \\
\hline \multicolumn{14}{|c|}{ Redundant Digital Logic Card - 67A LOGIC-64 } \\
\hline JUMPER & 1 & 2 & 3 & 4 & 5 & 6 & 7 & 8 & 9 & 10 & 11 & 12 & 13 \\
\hline POSITION & $B$ & A & $B$ & A & $B$ & A & A & 8 & $A$ & $A$ & B & $A$ & $B$ \\
\hline
\end{tabular}

Transmitter Card - 67 TRANS

\begin{tabular}{|c|c|c|c|c|c|c|c|c|c|}
\hline JUMPER & Ch. A & \multicolumn{3}{|c|}{ Ch. B } \\
\hline POSITION & B & \multicolumn{2}{|c|}{ F } \\
\hline \multicolumn{8}{|c|}{ Interface Card - 67A Inter-1 } \\
\hline JUMPER & A & B & C & D & E & F & G & H & $K$ \\
\hline POSITION & $-10 \mathrm{dBm}$ & $4 \mathrm{~W}$ & $4 \mathrm{~W}$ & OUT & OUT & DIR & ST & ST & IN \\
\hline
\end{tabular}

Low Receiver Card - 67B REC LO

\begin{tabular}{|c|c|}
\hline JUMPER & 1 \\
\hline POSITION & F \\
\hline
\end{tabular}

High Receiver Card - 67B REC HI

\begin{tabular}{|c|c|}
\hline JUMPER & 1 \\
\hline POSITION & $F$ \\
\hline
\end{tabular}

\begin{tabular}{|c|c|c|c|c|c|c|c|c|}
\hline JUMPER & A & B & C & D & E & F & G & H \\
\hline POSITION & USED & $\begin{array}{c}\text { NOT } \\
\text { USED }\end{array}$ & $\begin{array}{c}\text { NOT } \\
\text { USED }\end{array}$ & USED & $\begin{array}{c}\text { NOT } \\
\text { USED }\end{array}$ & USED & USED & $\begin{array}{c}\text { NOT } \\
\text { USED }\end{array}$ \\
\hline
\end{tabular}

Signal Level Card - 67A LEVEL IND

\begin{tabular}{|c|c|c|c|c|c|c|c|c|c|}
\hline JUMPER & 1 & 2 & 3 & 4 & 5 & 6 & 7 & 8 & 9 \\
\hline POSITION & DIR & DIR & $5 \mathrm{dBm}$ & $15 \mathrm{dBm}$ & $\mathrm{A}$ & $\mathrm{A}$ & $\mathrm{A}$ & $\mathrm{A}$ & $\mathrm{A}$ \\
\hline
\end{tabular}


BREAKER: A-382

Main Analog Logic Card - 67A LOGIC.63

\begin{tabular}{|c|c|c|c|c|c|}
\hline JUMPER & 1 & 2 & 3 & 4 & 5 \\
\hline POSITION & A & A & A & A & A \\
\hline
\end{tabular}

Main Digital Logic Card - 67A LOGIC-63

\begin{tabular}{|c|c|c|c|c|c|c|c|c|c|c|c|c|c|}
\hline JUMPER & 1 & 2 & 3 & 4 & 5 & 6 & 7 & 8 & 9 & 10 & 11 & 12 & 13 \\
\hline POSITION & $\mathrm{A}$ & $\mathrm{B}$ & $\mathrm{A}$ & $\mathrm{B}$ & $\mathrm{A}$ & $\mathrm{A}$ & $\mathrm{A}$ & $\mathrm{A}$ & $\mathrm{A}$ & $\mathrm{A}$ & $\mathrm{B}$ & $\mathrm{A}$ & $\mathrm{B}$ \\
\hline
\end{tabular}

Redundant Digital Logic Card - 67 A LOGIC-64

\begin{tabular}{|c|c|c|c|c|c|c|c|c|c|c|c|c|c|}
\hline JUMPER & 1 & 2 & 3 & 4 & 5 & 6 & 7 & 8 & 9 & 10 & 11 & 12 & 13 \\
\hline POSITION & B & A & B & A & B & A & A & B & A & A & B & A & B \\
\hline
\end{tabular}

Transmitter Card - 67 TRANS

\begin{tabular}{|c|c|c|}
\hline JUMPER & Ch. A & Ch. B \\
\hline POSITION & B & F \\
\hline
\end{tabular}

Interface Card - 67A Inter-1

\begin{tabular}{|c|c|c|c|c|c|c|c|c|c|}
\hline JUMPER & A & B & C & D & E & F & G & H & K \\
\hline POSITION & $-10 \mathrm{dBm}$ & $4 \mathrm{~W}$ & $4 \mathrm{~W}$ & OUT & OUT & DIR & ST & ST & IN \\
\hline
\end{tabular}

Low Receiver Card - 67B REC LO

JUMPER

POSITION

High Receiver Card - 67B REC HI

JUMPER

\begin{tabular}{l|l|}
\hline POSITION & $F$ \\
\hline
\end{tabular}

FS/AM Detector Card - 67FS/AM

\begin{tabular}{|c|c|c|c|c|c|c|c|c|}
\hline JUMPER & A & B & C & D & E & F & G & H \\
\hline POSITION & USED & $\begin{array}{c}\text { NOT } \\
\text { USED }\end{array}$ & $\begin{array}{c}\text { NOT } \\
\text { USED }\end{array}$ & USED & $\begin{array}{c}\text { NOT } \\
\text { USED }\end{array}$ & USED & USED & $\begin{array}{c}\text { NOT } \\
\text { USED }\end{array}$ \\
\hline
\end{tabular}

Signal Level Card - 67A LEVEL IND

\begin{tabular}{|c|c|c|c|c|c|c|c|c|c|}
\hline JUMPER & 1 & 2 & 3 & 4 & 5 & 6 & 7 & 8 & 9 \\
\hline POSITION & DIR & DIR & $5 \mathrm{dBm}$ & $15 \mathrm{dBm}$ & $\mathrm{A}$ & $\mathrm{A}$ & $\mathrm{A}$ & $\mathrm{A}$ & $\mathrm{A}$ \\
\hline
\end{tabular}


BREAKER: A-386

Main Analog Logic Card - 67A LOGIC-63

\begin{tabular}{|c|c|c|c|c|c|}
\hline JUMPER & 1 & 2 & 3 & 4 & 5 \\
\hline POSITION & A & A & A & A & A \\
\hline
\end{tabular}

Main Digital Logic Card - 67A LOGIC-63

\begin{tabular}{|c|c|c|c|c|c|c|c|c|c|c|c|c|c|}
\hline JUMPER & 1 & 2 & 3 & 4 & 5 & 6 & 7 & 8 & 9 & 10 & 11 & 12 & 13 \\
\hline POSITION & $\mathrm{A}$ & $\mathrm{B}$ & $\mathrm{A}$ & $\mathrm{B}$ & $\mathrm{A}$ & $\mathrm{A}$ & $\mathrm{A}$ & $\mathrm{A}$ & $\mathrm{A}$ & $\mathrm{A}$ & $\mathrm{B}$ & $\mathrm{A}$ & $\mathrm{B}$ \\
\hline
\end{tabular}

Redundant Digita! Logic Card - 67A LOGJC-64

\begin{tabular}{|c|c|c|c|c|c|c|c|c|c|c|c|c|c|}
\hline JUMPER & 1 & 2 & 3 & 4 & 5 & 6 & 7 & 8 & 9 & 10 & 11 & 12 & 13 \\
\hline POSITION & $\mathrm{B}$ & $\mathrm{A}$ & $\mathrm{B}$ & $\mathrm{A}$ & $\mathrm{B}$ & $\mathrm{A}$ & $\mathrm{A}$ & $\mathrm{B}$ & $\mathrm{A}$ & $\mathrm{A}$ & $\mathrm{B}$ & $\mathrm{A}$ & $\mathrm{B}$ \\
\hline
\end{tabular}

Transmitter Card -67 TRANS

\begin{tabular}{|c|c|c|}
\hline JUMPER & Ch. A & Ch. B \\
\hline POSITION & B & F \\
\hline
\end{tabular}

Interface Card - 67A Inter-1

\begin{tabular}{|c|c|c|c|c|c|c|c|c|c|}
\hline JUMPER & $\mathrm{A}$ & $\mathrm{B}$ & $\mathrm{C}$ & $\mathrm{D}$ & $\mathrm{E}$ & $\mathrm{F}$ & $\mathrm{G}$ & $\mathrm{H}$ & $K$ \\
\hline POSITION & $-10 \mathrm{dBm}$ & $4 \mathrm{~W}$ & $4 \mathrm{~W}$ & OUT & OUT & DIR & $\mathrm{ST}$ & $\mathrm{ST}$ & IN \\
\hline
\end{tabular}

Low Receiver Card - 67B REC LO JUMPER \begin{tabular}{|l|l|}
\hline POSITION & $F$ \\
\hline
\end{tabular}

High Receiver Card - 67E REC HI JUMPER \begin{tabular}{|l|l|}
\hline POSITION & $\mathbf{F}$ \\
\hline
\end{tabular}

FS/AM Detector Card - 67FS/AM

\begin{tabular}{|c|c|c|c|c|c|c|c|c|}
\hline JUMPER & A & B & C & D & E & F & G & $H$ \\
\hline POSITION & USED & $\begin{array}{c}\text { NOT } \\
\text { USED }\end{array}$ & $\begin{array}{c}\text { NOT } \\
\text { USED }\end{array}$ & USED & $\begin{array}{c}\text { NOT } \\
\text { USED }\end{array}$ & USED & USED & $\begin{array}{c}\text { NOT } \\
\text { USED }\end{array}$ \\
\hline
\end{tabular}

Signal Level Card - 67A LEVEL, IND

\begin{tabular}{|c|c|c|c|c|c|c|c|c|c|}
\hline JUMPER & 1 & 2 & 3 & 4 & 5 & 6 & 7 & 8 & 9 \\
\hline POSITION & DIR & DIR & $5 \mathrm{dBm}$ & $15 \mathrm{dBm}$ & $\mathrm{A}$ & $\mathrm{A}$ & $\mathrm{A}$ & $\mathrm{A}$ & $\mathrm{A}$ \\
\hline
\end{tabular}


FREQUENCYITONE LEVELS

\begin{tabular}{|c|c|c|c|c|c|}
\hline OCB & $\begin{array}{c}\text { Tone } \\
\text { Levels }\end{array}$ & $\begin{array}{c}\text { Guard } \\
\text { T1-Ch A }\end{array}$ & $\begin{array}{c}\text { Trip } \\
\text { T1-Ch A }\end{array}$ & $\begin{array}{c}\text { Guard } \\
\text { T2-Ch B }\end{array}$ & $\begin{array}{c}\text { Trip } \\
\text { T2-Ch B }\end{array}$ \\
\hline \multirow{2}{*}{ A372 } & $\mathrm{HZ}$ & 1765 & 1465 & 2145 & 2445 \\
& $\mathrm{dBm}$ & -16.96 & -16.81 & -17.20 & -17.16 \\
\hline \multirow{2}{*}{$\mathrm{A} 376$} & $\mathrm{HZ}$ & 1765 & 1464 & 2145 & 2444 \\
& $\mathrm{dBm}$ & -17.26 & -17.10 & -17.37 & -17.24 \\
\hline \multirow{2}{*}{$\mathrm{A3382}$} & $\mathrm{HZ}$ & 1764 & 1464 & 2144 & 2444 \\
\hline & $\mathrm{dBm}$ & -17.82 & -17.77 & -18.13 & -17.77 \\
\hline \multirow{2}{*}{$\mathrm{A383}$} & $\mathrm{HZ}$ & 17.64 & 1464 & 2144 & 2445 \\
& $\mathrm{dBm}$ & -17.46 & -17.50 & -17.78 & -17.80 \\
\hline
\end{tabular}




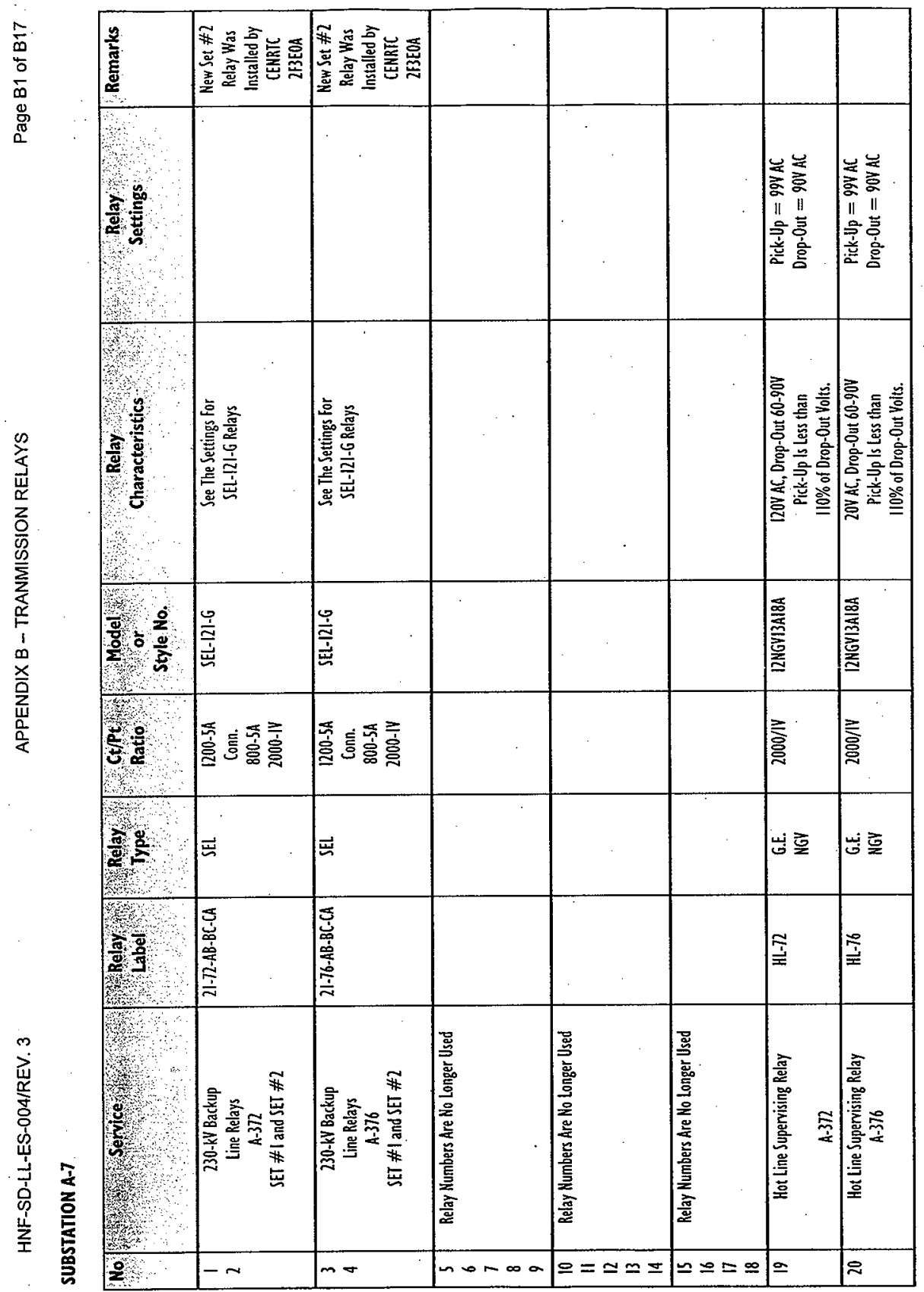




\section{SUBSTATION A-7}

\begin{tabular}{|c|c|c|c|c|c|c|c|c|}
\hline $\mathrm{No}$ & 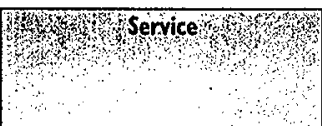 & Whelay & $\begin{array}{c}\text { Relay } \\
\text { Type }\end{array}$ & Ratio & $\begin{array}{l}\text { Model } \\
\text { or } \\
\text { Style No. }\end{array}$ & 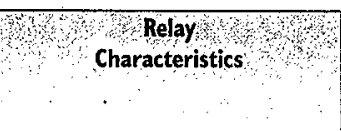 & $\begin{array}{l}\text { Relay } \\
\text { Settings }\end{array}$ & Remarks \\
\hline 21 & $\begin{array}{l}\text { Synch. Check } \\
\text { Relay A-372 }\end{array}$ & 72-SYMC & $\begin{array}{l}\text { W. } \\
\text { CVE-1 }\end{array}$ & $2000 / 1 \mathrm{~V}$ & $292 B 353 A 34$ & $\begin{array}{l}\text { 20V AC, Drop-Out } 60-90 \mathrm{~V} \\
\text { Pick-Up Is Less Than } \\
110 \% \text { of Drop-Out Volts. }\end{array}$ & $\begin{array}{c}\text { Closing Angle }=40 \text { Degrees } \\
\text { T.L. }=0.5 \text { to close the contact } \\
0.5 \text { seconds with } 0 \text { Degree Angle } \\
\text { Diff. }\end{array}$ & \\
\hline 22 & $\begin{array}{l}\text { Synch. Check } \\
\text { Relay A-3744 }\end{array}$ & 74-SYNC & $\begin{array}{l}\text { W. } \\
\text { CVE-I }\end{array}$ & $2000 / 14$ & $292 \mathrm{~B} 353 \mathrm{~A} 34$ & $\begin{array}{l}\text { 120V, 20-40-60 Degree, } \\
\text { Closing Angle Adjustment, } \\
\text { ICS = 0.2A, SPST.CC, } \\
\text { Adjustable Closing Time. }\end{array}$ & $\begin{array}{c}\text { Closing Angle }=40 \text { Degrees } \\
\text { T.L. }=0.5 \text { to close the contact } \\
0.5 \text { seconds with } 0 \text { Degree Angle Diff. }\end{array}$ & \\
\hline 23 & $\begin{array}{l}\text { Synch. Check } \\
\text { Relay A-376 }\end{array}$ & 76-SYNC & $\begin{array}{l}\text { W. } \\
\text { CVE-I }\end{array}$ & $2000 / 1 \mathrm{~V}$ & $292 \mathrm{~B} 353 \mathrm{A3} 4$ & $\begin{array}{l}\text { 120V, 20-40-60 Degree } \\
\text { Closing Angle Adjustment, } \\
\text { ICS = 0.2A, SPST-CC, } \\
\text { Adjustable Closing Time. }\end{array}$ & $\begin{array}{c}\text { Closing Angle }=40 \text { Degrees } \\
\text { T.L. }=0.5 \text { to close the contact } \\
0.5 \text { seconds with } 0 \text { Degree Angle } \\
\text { Diff. }\end{array}$ & \\
\hline 24 & $\begin{array}{l}\text { Breaker Failure } \\
\text { Relay A-372 }\end{array}$ & BFR-72 & $\underset{S B F-1}{W}$ & $\begin{array}{l}1200-5 A \\
\text { Conn. } \\
800-5 A\end{array}$ & $1529 \mathrm{~F} 93 \mathrm{~A} 05$ & $\begin{array}{c}\text { B.F. Timer }=25-175 \mathrm{~ms} \\
\text { Control Jimer }=150-250 \mathrm{~ms} \\
\text { Phase } 0 / \mathrm{C}=0.5 \cdot 13.5 \mathrm{~A} \\
\text { Ground } 0 / \mathrm{C}=0.5-13.5 \mathrm{~A} \\
\text { Target and Seal-1n }=0.2 / 2.0 \mathrm{~A}\end{array}$ & $\begin{array}{c}\text { B.F. Timer }=133 \mathrm{~ms} \\
\text { Control Timer }=166 \mathrm{~ms} \\
\text { Phase } 0 / \mathrm{C}=0.5 \mathrm{~A} \\
\text { Ground } 0 / \mathrm{C}=0.5 \mathrm{~A} \\
\text { Target and Seal-in }=0.2 \mathrm{~A}\end{array}$ & \\
\hline 25 & $\begin{array}{l}\text { Breaker Failure } \\
\text { Relay A-374 }\end{array}$ & BFR-74. & $\begin{array}{l}\text { W. } \\
\text { SBF- }\end{array}$ & $\begin{array}{l}1200-5 A \\
\text { Conn. } \\
800-5 A\end{array}$ & 1529F93A05 & $\begin{array}{c}\text { B.F. Timer }=25.175 \mathrm{~ms} \\
\text { Control Timer }=150-250 \mathrm{~ms} \\
\text { Phase } 0 / \mathrm{C}=0.5-13.5 \mathrm{~A} \\
\text { Ground } 0 / \mathrm{C}=0.5-13.5 \mathrm{~A} \\
\text { Target and Seal-ln }=0.2 / 2.0 \mathrm{~A}\end{array}$ & $\begin{array}{c}\text { B.F. Timer }=133 \mathrm{~ms} \\
\text { Control Timer }=166 \mathrm{~ms} \\
\text { Phase } 0 / C=0.5 \mathrm{~A} \\
\text { Ground } 0 / \mathrm{C}=0.5 \mathrm{~A} \\
\text { Target and Seal--ln }=0.2 \mathrm{~A}\end{array}$ & \\
\hline 26 & $\begin{array}{c}\text { Breaker Failure } \\
\text { Relay A-376 }\end{array}$ & BFR-76 & $\begin{array}{l}\text { W. } \\
\text { SBF-I }\end{array}$ & $\begin{array}{l}1200-5 A \\
\text { Conn. } \\
\text { 800-5A }\end{array}$ & 1529593405 & $\begin{array}{c}\text { B.F. Timer }=25-175 \mathrm{~ms} \\
\text { Control Timer }=150-250 \mathrm{~ms} \\
\text { Phase } 0 / \mathrm{C}=0.5-13.5 \mathrm{~A} \\
\text { Ground } 0 / \mathrm{C}=0.5-13.5 \mathrm{~A} \\
\text { Target and Seal-In }=0.2 / 2.0 \mathrm{~A}\end{array}$ & $\begin{array}{c}\text { B.F. Timer }=133 \mathrm{~ms} \\
\text { Control Timer }=166 \mathrm{~ms} \\
\text { Phase } 0 / \mathcal{C}=0.5 \mathrm{~A} \\
\text { Ground } 0 / \mathcal{C}=0.5 \mathrm{~A} \\
\text { Target and Seal- }-\mathrm{ln}=0.2 \mathrm{~A}\end{array}$ & \\
\hline 27 & $\begin{array}{l}\text { 230-kV Backup } \\
\text { Ground Relay } \\
\text { A-372 }\end{array}$ & $67 \mathrm{~GB}-72$ & $\begin{array}{l}\text { G.E. } \\
\text { JBCG }\end{array}$ & $\begin{array}{l}1200-5 A \\
\text { Conn. } \\
800 A \\
1150-1 V\end{array}$ & I2\}BCG53KIIY & $\begin{array}{c}\text { Time } 0 / C=1.5-6.0 \mathrm{~A} \\
\text { Dir. Inst. } 0 / C=10-40 \mathrm{~A} \\
\text { Non-Dir. Inst. } 0 / C=2-8 \mathrm{~A} \\
\text { Max Torque Angle }=60 \text { Degree } \\
\text { Target and Seal-In }=0.22 .0 \mathrm{~A}\end{array}$ & $\begin{array}{c}\text { T/O/C Tap }=1.5 \mathrm{~A}, \mathrm{TD}=4 \\
\text { Dir. Inst. } 0 / \mathrm{C}=15 \mathrm{~A} \\
\text { Non-Dir. Inst. } 0 / \mathrm{C}=8 \mathrm{~A} \\
\text { Max Torque Angle }=60 \text { Degree } \\
\text { Target and Seal-In }=2.0 \mathrm{~A}\end{array}$ & REYIJ \\
\hline
\end{tabular}




\section{SUBSTATION A-7}

\begin{tabular}{|c|c|c|c|c|c|c|c|c|}
\hline $\mathrm{No}$ & 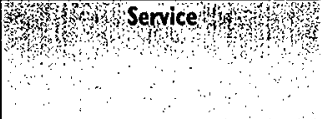 & 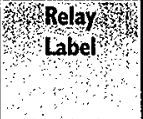 & $\begin{array}{l}\text { Relay } \\
\text { Type }\end{array}$ & $\begin{array}{l}\text { Ct/pt } \\
\text { Ratio }\end{array}$ & $\begin{array}{l}\text { Model } \\
\text { or } \\
\text { Style No. }\end{array}$ & $\begin{array}{c}\text { Whelay } \\
\text { Characteristics }\end{array}$ & Settings & Remarks \\
\hline 28 & $\begin{array}{l}\text { 230-kV Backup } \\
\text { Ground Relay } \\
\text { A-376 }\end{array}$ & $\begin{array}{c}676 B-76 \\
\ldots\end{array}$ & $\begin{array}{l}\text { G.E. } \\
\text { JBCG }\end{array}$ & $\begin{array}{l}1200-5 A \\
\text { Conn. } \\
800-5 A \\
1150-1 Y\end{array}$ & $\begin{array}{c}\text { I2]BCG53KIIY } \\
\text { IA }\end{array}$ & $\begin{array}{c}\text { Time } 0 / C=1.5-6.0 \mathrm{~A} \\
\text { Dir. Inst. } 0 / \mathrm{C}=10-40 \mathrm{~A} \\
\text { Non-Dir. Inst. } 0 / \mathrm{C}=2-8 \mathrm{~A} \\
\text { Max Torque Angle }=60 \text { Degree } \\
\text { Target and Seal-In }=0.2 / 2.0 \mathrm{~A}\end{array}$ & $\begin{array}{c}\mathrm{T} / 0 / \mathrm{C} \text { Tap }=4 \mathrm{~A}, \mathrm{TD}=5.5 \\
\text { Dir. Inst. } 0 / \mathrm{C}=\mathrm{Block} \\
\text { Non-Dir. Inst. } 0 / \mathrm{C}=8 \mathrm{~A} \\
\text { Max Torque Angle }=60 \text { Degree } \\
\text { Target and Seal-In }=2.0 \mathrm{~A}\end{array}$ & REVIJ \\
\hline $\begin{array}{l}29 \\
30 \\
\end{array}$ & Relay Numbers are No Longer Used & $\therefore$ & & & & & & \\
\hline $\begin{array}{l}31 \\
32 \\
33\end{array}$ & $\begin{array}{c}\text { 230-kV Bus No. I } \\
\text { Diff. Relays }\end{array}$ & 87BI-TH-A-B-C & $\begin{array}{l}\text { G.E. } \\
\text { PVD }\end{array}$ & $1200-5$ & I2PVDIICIA & $\begin{array}{c}120 \mathrm{~V}, 60 \mathrm{~Hz}, 87 \mathrm{~L}=75-500 \mathrm{~V}, \\
87 \mathrm{H}=2-50 \mathrm{~A}, \text { Single-Phase, } \\
\text { Target and Seaj- }-\mathrm{ln}=0.22 .0 \mathrm{~A}\end{array}$ & $\begin{array}{c}87 \mathrm{~L}=200 \text { Voits } \\
87 \mathrm{H}=2.0 \mathrm{Amps} \\
\text { Target and Seal- } \ln =0.2 \mathrm{~A}\end{array}$ & \\
\hline $\begin{array}{l}34 \\
35 \\
36 \\
\end{array}$ & $\begin{array}{c}\text { 230-kV Bus No.2 } \\
\text { Diff. Relays }\end{array}$ & 87B2-TH-A-B-C & $\begin{array}{l}\text { G.E. } \\
\text { PVD }\end{array}$ & $1200-5$ & IIPVDIICIA & $\begin{array}{l}120 \mathrm{~V}, 60 \mathrm{~Hz}, 87 \mathrm{~L}=75-500 \mathrm{~V}, \\
87 \mathrm{H}=2-50 \mathrm{~A}, \text { Single-Phase, } \\
\text { Target and Seal-In }=0.2 / 2.0 \mathrm{~A}\end{array}$ & $\begin{array}{c}87 \mathrm{~L}=200 \text { Volts } \\
87 \mathrm{H}=2.0 \mathrm{Amps} \\
\text { Target and Seal-In }=0.2 \mathrm{~A}\end{array}$ & \\
\hline $\begin{array}{l}37 \\
38 \\
39\end{array}$ & $\begin{array}{c}\text { 230-kV Bank No. I } \\
\text { Diff. Relays }\end{array}$ & $87 I L I-A-B-C$ & $\begin{array}{c}\text { B.E. } \\
\text { BEI-87T }\end{array}$ & $\begin{array}{c}600-5 \\
400 \text { A H.Y. } \\
2000-5 \text { L.Y. }\end{array}$ & AIEAJJDOSSF & $\begin{array}{l}\text { Two Winding Restraints, } \\
\text { Adjustable Taps, } \\
\text { Adjustable Sensitivity } \\
\text { Adjustable Slope }\end{array}$ & $\begin{array}{l}\text { H.V. (Input 2) Tap }=2.0 \mathrm{~A} \\
\text { L.V. (Input I) Tap }=3.7 \mathrm{~A} \\
\text { Slope }=25 \% \\
\text { Unrestrained Trip }=12 \mathrm{~A} \\
\quad \text { Target }=0.2 \mathrm{~A}\end{array}$ & $\begin{array}{l}\text { New Relay } \\
\text { CENRIC } \\
\text { 2F3EOA }\end{array}$ \\
\hline $\begin{array}{l}40 \\
41 \\
42\end{array}$ & $\begin{array}{l}\text { 230-kV Bank No. } 2 \\
\text { Diff. Relays }\end{array}$ & $87 \mathrm{IL} 2-\mathrm{A}-\mathrm{B}-\mathrm{C}$ & $\begin{array}{c}\text { B.E. } \\
\text { BEI-87T }\end{array}$ & $\begin{array}{c}6000-5 \\
400 A \text { H.Y. } \\
2000-5 \text { L.Y. }\end{array}$ & AIEAIJDOSSF & $\begin{array}{l}\text { Two Winding Restraints, } \\
\text { Adjustable Taps, } \\
\text { Adjustable Sensitivity } \\
\text { Adjustable Slope }\end{array}$ & $\begin{array}{l}\text { H.V. (Input 2) Tap }=2.0 \mathrm{~A} \\
\text { L.V. (Input I) Tap }=3.7 \mathrm{~A} \\
\text { Slope }=25 \% \\
\text { Unrestrained Trip }=12 \mathrm{~A} \\
\text { Target }=0.2 \mathrm{~A} \\
\end{array}$ & $\begin{array}{l}\text { Hew Relay } \\
\text { CENRIC } \\
\text { 2F3EOA }\end{array}$ \\
\hline $\begin{array}{l}43 \\
44 \\
45 \\
\end{array}$ & $\begin{array}{c}\text { 230-kV Bank No. I } \\
\text { O/C. Relays }\end{array}$ & 50/SI-IHI-A-B-C & $\begin{array}{l}W . \\
C 0-9\end{array}$ & $800-5$ & $264 C 901403$ & $\begin{array}{l}\text { Time } 0 / C=0.5-2.5 \mathrm{~A} \\
\text { Inst. } 0 / C=2.0-48 \mathrm{~A}\end{array}$ & $\begin{array}{l}\text { Tap }=1 \mathrm{~A} \\
\text { T.D. }=4.0 \\
\text { Inst }=6 \mathrm{~A}\end{array}$ & $\begin{array}{l}\text { 1.35 Seconds } \\
@ 4 A\end{array}$ \\
\hline $\begin{array}{l}46 \\
47 \\
48\end{array}$ & $\begin{array}{c}\text { 230-kV Bank No. } 2 \\
\text { O/C. Relays }\end{array}$ & $50 / S 1-T H 2-A-B-C$ & $\begin{array}{l}\text { W. } \\
\text { C0-9 }\end{array}$ & $800-5$ & 264 C901A03 & $\begin{array}{l}\text { Time } 0 / \mathrm{C}=0.5-2.5 \mathrm{~A} \\
\text { Inst. } 0 / \mathrm{C}=2.0-48 \mathrm{~A}\end{array}$ & $\begin{array}{l}\text { Tap }=1 \mathrm{~A} \\
\text { T.D. }=4.0 \\
\operatorname{lnst}=6 \mathrm{~A}\end{array}$ & \\
\hline 49 & $\begin{array}{l}\text { Auto-Reclosing } \\
\text { Relay } \\
\text { A-372 }\end{array}$ & $79-72$ & $\begin{array}{l}\text { G.E. } \\
\text { ACR }\end{array}$ & - & |2ACRI|BI4A8 & & $\begin{array}{l}\text { Single-Shot Reclosing } \\
\text { After } 6.0 \text { Seconds. }\end{array}$ & $\begin{array}{l}1.35 \text { seconds } \\
@ 4 A\end{array}$ \\
\hline
\end{tabular}




\section{SUBSTATION A-7}

\begin{tabular}{|c|c|c|c|c|c|c|c|c|}
\hline Not & Where & Wabel & Type & Ratio & $\begin{array}{l}\text { Modely } \\
\text { or } \\
\text { style No. }\end{array}$ & 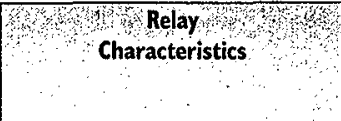 & $\begin{array}{c}\text { Whe Rey } \\
\text { Settings } \\
\text { S }\end{array}$ & Remarks \\
\hline 50 & $\begin{array}{l}\text { Auto-Reclosing } \\
\text { Relay } \\
\text { A-376. }\end{array}$ & $79-76$ & $\begin{array}{l}\text { G.E. } \\
A C R\end{array}$ & - & |2ACRI|B|4AB & & $\begin{array}{l}\text { Single-Shot Reclosing } \\
\text { After } 4.0 \text { Seconds. }\end{array}$ & $\begin{array}{l}\text { 1.35 Seconds } \\
\text { @ 4A }\end{array}$ \\
\hline 51 & $\begin{array}{l}\text { 230-kV Bank No.I } \\
\text { Meutral O/C. Relay }\end{array}$ & SIG-THI & $\begin{array}{l}\text { G.E. } \\
\text { IAC }\end{array}$ & $600-5$ & 12IAC53B803A & $\begin{aligned} \operatorname{Time} 0 / \mathrm{C} & =0.5-4.0 \mathrm{~A} \\
\text { lnst. } 0 / \mathrm{C} & =2.0-16 \mathrm{~A}\end{aligned}$ & $\begin{array}{c}\text { Time } 0 / C \text { Tap }=2.0 \mathrm{~A} \\
\text { T.L. }=3 \\
\text { Inst. } 0 / \mathrm{C}=\text { Blocked. }\end{array}$ & \\
\hline 52 & $\begin{array}{l}230-k V \text { Bank No. } 2 \\
\text { Heutral O/C. Relay }\end{array}$ & SIG-TH2 & $\begin{array}{l}\text { G.E. } \\
\text { IAC }\end{array}$ & $600-5$ & $121 \mathrm{AC} 53 \mathrm{~B} 803 \mathrm{~A}$ & $\begin{array}{c}\text { Time } 0 / \mathrm{C}=0.5-4.0 \mathrm{~A} \\
\text { Inst. } 0 / \mathrm{C}=2.0-16 \mathrm{~A}\end{array}$ & $\begin{array}{c}\text { Time } 0 / C \text { Tap }=2.0 \mathrm{~A} \\
\text { T.L. }=3 \\
\text { Inst. } 0 / \mathrm{C}=\text { Blocked. }\end{array}$ & \\
\hline 53 & $\begin{array}{c}\text { lig-lag Grounding } \\
\text { Bank Neutral O/C } \\
\text { Alarm Relay } \\
\text { Bank No.I }\end{array}$ & 50G-GTI & $\begin{array}{l}\text { G.E. } \\
\text { PJC }\end{array}$ & $600-5$ & I2P]CIIAVIA & inst. $0 / C=0.5-2.5 \mathrm{~A}$ & $\begin{array}{c}\text { Inst }=0.5 \mathrm{~A} \\
60 \text { Amps Primary } \\
\text { Alarm Only }\end{array}$ & $\begin{array}{c}0.5 \text { Seconds } \\
@ 16 A\end{array}$ \\
\hline 54 & $\begin{array}{c}\text { Zig-lag Grounding } \\
\text { Bank Neutral 0/C } \\
\text { Alarm Relay } \\
\text { Bank No.2 } \\
\end{array}$ & 50G-GR & $\begin{array}{l}\text { G.E. } \\
\text { PJC }\end{array}$ & $600-5$ & |2PJCIIAVIA & Inst. $0 / C=0.5-2.5 \mathrm{~A}$ & $\begin{array}{l}\text { Inst }=0.5 A \\
60 \text { Amps Primary } \\
\text { Alarm Oniy }\end{array}$ & $\begin{array}{c}0.5 \text { Seconds } \\
@ 16 A\end{array}$ \\
\hline $\begin{array}{l}55 \\
56 \\
57\end{array}$ & $\begin{array}{l}\text { Tig-Lag Grounding } \\
\text { Bank 0/C Relays } \\
\text { Bank No. I }\end{array}$ & SI-GTI-A-B-C & $\begin{array}{l}\text { G.E. } \\
\text { IAC }\end{array}$ & $400-5$ & DIACSIAIA & $\begin{array}{c}\text { Time } 0 / C=4.0-16 \mathrm{~A} \\
\text { Target and Seal- } \mathrm{ln}=0.2 / 2.0 \mathrm{~A}\end{array}$ & $\begin{array}{c}\text { Tap }=4.0 \mathrm{~A} \\
\mathrm{~T} . \mathrm{D} .=1.0 \\
\text { Target and Seal- } \mathrm{In}=0.2 \mathrm{~A}\end{array}$ & \\
\hline $\begin{array}{l}58 \\
59 \\
60\end{array}$ & $\begin{array}{l}\text { Zig.Zag Grounding } \\
\text { Bank 0/C Relays } \\
\text { Bank No.2 }\end{array}$ & $51-G D-A-B \cdot C$ & $\begin{array}{l}\text { G.E. } \\
\text { IAC }\end{array}$ & $400-5$ & IZIACSIALA & $\begin{array}{c}\text { Time } 0 / C=4.0-16 \mathrm{~A} \\
\text { Target and Seal- } \ln =0.2 / 2.0 \mathrm{~A}\end{array}$ & $\begin{array}{c}\text { Tap }=4.0 \mathrm{~A} \\
\text { T.D. }=1.0 \\
\text { Target and Seal }-\ln =0.2 \mathrm{~A}\end{array}$ & \\
\hline 61 & $\begin{array}{c}\text { Zig-Lag Grounding } \\
\text { Bank Neutral } 0 / C \\
\text { Relay } \\
\text { Bank No. I } \\
\end{array}$ & SIGB-GTI & $\begin{array}{l}\text { G.E. } \\
\text { IAC }\end{array}$ & $\begin{array}{l}1200-5 A^{\circ} \\
\text { Conn. } \\
600-5 A\end{array}$ & 12IAC77B803A & $\begin{array}{c}\text { Time } 0 / \mathrm{C}=0.5-4.0 \mathrm{~A} \\
\text { Target and Seal-In }=0.2 / 2.0 \mathrm{~A}\end{array}$ & $\begin{array}{c}\text { Tap }=2.5 \mathrm{~A} \\
\text { T.D. }=10 \\
\text { Target and Seal- } \ln =0.2 \mathrm{~A}\end{array}$ & $\begin{array}{c}0.6 \text { Seconds } \\
\text { @ } 12 \mathrm{~A}\end{array}$ \\
\hline
\end{tabular}




\section{SUBSTATION A-7}

\begin{tabular}{|c|c|c|c|c|c|c|c|c|}
\hline $\mathrm{No}_{\mathrm{i}}$ & 3ry & WLabel & $\begin{array}{l}\text { Relay } \\
\text { Type }\end{array}$ & 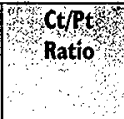 & $\begin{array}{l}\text { Model } \\
\text { ort } \\
\text { Style No. }\end{array}$ & $\begin{array}{l}\text { Characteristics } \\
\text { C }\end{array}$ & $\begin{array}{c}\text { Relay } \\
\text { Settings }\end{array}$ & Remarks \\
\hline 62 & $\begin{array}{c}\text { Zig-Zag Grounding } \\
\text { Bank Neutral 0/C } \\
\text { Relay } \\
\text { Bank No. } 2\end{array}$ & 5IGB-GI2 & $\begin{array}{l}\text { G.E. } \\
\text { IAC }\end{array}$ & $\begin{array}{l}1200-5 A \\
\text { Conn. } \\
600-5 A\end{array}$ & 121AC77B803A & $\begin{array}{c}\text { Time } 0 / \mathrm{C}=0.5 \cdot 4.0 \mathrm{~A} \\
\text { Target and Seal-ln }=0.2 / 2.0 \mathrm{~A}\end{array}$ & $\begin{array}{c}\text { Tap }=2.5 \mathrm{~A} \\
T .0=10 \\
\text { Target and Seal- } \ln =0.2 \mathrm{~A}\end{array}$ & $\begin{array}{c}0.6 \text { Seconds } \\
@ 12 A\end{array}$ \\
\hline
\end{tabular}




\section{SUBSTATION A-8}

\begin{tabular}{|c|c|c|c|c|c|c|c|c|}
\hline No & Whervice & Relay Label & $\begin{array}{l}\text { Relay } \\
\text { Type }\end{array}$ & Ratio & $\begin{array}{l}\text { Model or } \\
\text { Serial No. }\end{array}$ & W/ Relay Characteristics & Relay Settings 4 & Remarks \\
\hline $\begin{array}{l}1 \\
2\end{array}$ & $\begin{array}{l}\text { 230-kV Backup } \\
\text { Line Relays } \\
\text { A-382 } \\
\text { Set\#1 and \#2 }\end{array}$ & $21-82-A B-B C \cdot C A$ & SEL & $\begin{array}{l}1200-5 A \\
\text { Conn. } \\
800-5 A \\
2000-11\end{array}$ & SEL-I2I-G & $\begin{array}{l}\text { See the Settings for } \\
\text { SEL-I2I-G Relays }\end{array}$ & & $\begin{array}{c}\text { New Set \#2 } \\
\text { Relay was installed by } \\
\text { CENRTC } \\
\text { 2F3EOA }\end{array}$ \\
\hline $\begin{array}{l}3 \\
4\end{array}$ & $\begin{array}{c}\text { 230-kV Backup } \\
\text { Line Relays } \\
\text { A-386 } \\
\text { Set\#1 and \#2 }\end{array}$ & $21-86-A B-B C-C A$ & SEL & $\begin{array}{l}1200-5 A \\
\text { Conn. } \\
800-5 A \\
2000-1 V\end{array}$ & SEL-12I-G & $\begin{array}{l}\text { See the Settings for } \\
\text { SEL-IZI-G Relays }\end{array}$ & . & $\begin{array}{c}\text { New Set\#2 } \\
\text { Relay was instalied by } \\
\text { CENRTC } \\
\text { 2F3EOA }\end{array}$ \\
\hline $\begin{array}{l}5 \\
6 \\
\end{array}$ & $\begin{array}{c}\text { Relay Numbers } \\
\text { Are Ho Longer Used }\end{array}$ & & & & & . & & 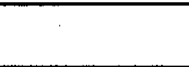 \\
\hline $\begin{array}{l}7 \\
8 \\
9\end{array}$ & $\begin{array}{l}\text { 230-kV Backup } \\
\text { Line Relays } \\
\text { A-38B }\end{array}$ & 21-88-AB-BC-CA & SEL & $\begin{array}{l}1200-5 A \\
\text { Conn. } \\
800-5 A \\
2000-1 V\end{array}$ & SEL-121-G & $\begin{array}{c}\text { See the Settings for } \\
\text { SEL-I21-G Relays } \\
.\end{array}$ & $\begin{array}{l}\text { Relay has been removed } \\
\text { from service as part of } \\
\text { CENRTC Project \#2F3EOA }\end{array}$ & $\begin{array}{l}\text { Relay is no longer in } \\
\text { service. }\end{array}$ \\
\hline $\begin{array}{l}10 \\
11 \\
\end{array}$ & $\begin{array}{c}\text { Relay Numbers } \\
\text { Are No Longer Used }\end{array}$ & & & $x$ & & & & \\
\hline 12 & $\begin{array}{c}\text { 230-kV Carrier } \\
\text { Tripping Relay } \\
\text { A-38B }\end{array}$ & $21 M-88$ & $\begin{array}{l}\text { G.E. } \\
\text { CEY }\end{array}$ & $\begin{array}{l}1200-5 A \\
\text { Conn. } \\
800-5 A \\
2000-1 V\end{array}$ & 12CEY52A3D & $\begin{array}{l}\text { MHO Unit }=0.5-150 \mathrm{HM} \\
\text { Max Torque Angle }=60 \text { Degree } \\
\text { Target and Seal- } \mathrm{In}=0.222 .0 \mathrm{~A} .\end{array}$ & $\begin{array}{l}\text { Relay has been removed } \\
\text { from service as part of } \\
\text { CENRTC Project \#2F3EOA }\end{array}$ & $\begin{array}{l}\text { Relay is no longer in } \\
\text { service. }\end{array}$ \\
\hline $\begin{array}{l}13 \\
14 \\
\end{array}$ & $\begin{array}{c}\text { Relay Numbers } \\
\text { Are No Longer Used }\end{array}$ & & & & . & & & \\
\hline 15 & $\begin{array}{c}\text { 230-kV Carrier } \\
\text { Starting Relay } \\
\text { A-388 }\end{array}$ & $68-88$ & $\begin{array}{l}\text { G.E. } \\
\text { CEB }\end{array}$ & $\begin{array}{l}1200-5 A \\
\text { Conn. } \\
800-5 A \\
2000-18\end{array}$ & . I2CEBS2A9D & $\begin{array}{c}\text { MHO Unit }=0.5-15 \text { OHM } \\
\text { Off Set MH } 0=0-0.25 \text { OHM } \\
\text { Max Torque Angle }=75 \text { Degree } \\
\text { Target and Seal-In }=0.22 .0 \mathrm{~A}\end{array}$ & $\begin{array}{l}\text { Relay has been removed } \\
\text { from service as part of } \\
\text { CENRTC Project \#2F3E0A }\end{array}$ & $\begin{array}{c}\text { Relay is no longer in } \\
\text { service. } \\
\text { : }\end{array}$ \\
\hline $\begin{array}{l}16 \\
17 \\
\end{array}$ & $\begin{array}{c}\text { Relay Numbers } \\
\text { Are No Longer Used }\end{array}$ & & & & & & . & \\
\hline 18 & $\begin{array}{l}\text { Fault Detector } \\
\text { A. } 388\end{array}$ & FD-88 & $\begin{array}{l}\text { W. } \\
\text { KC-4 }\end{array}$ & $\begin{array}{l}1200-5 A \\
\text { Conn. } \\
800-5 A\end{array}$ & $293 B 004 A 14$ & $\begin{array}{c}\text { Phase } 0 / C=2.0-8.0 \mathrm{~A} \\
\text { Ground } 0 / C=1.0-4.0 \mathrm{~A} \\
\text { Target and Seal- } \ln =0.2 / 2.0 \mathrm{~A}\end{array}$ & $\begin{array}{l}\text { Relay has been removed } \\
\text { from service as part of } \\
\text { CENRTC Project \#2F3EOA }\end{array}$ & $\begin{array}{l}\text { Relay is no longer in } \\
\text { service. }\end{array}$ \\
\hline
\end{tabular}




\section{SUBSTATION A-8}

\begin{tabular}{|c|c|c|c|c|c|c|c|c|}
\hline $\mathrm{No}$ & Whervice & Relay/labelo & $\begin{array}{l}\text { Relay } \\
\text { Type }\end{array}$ & $\begin{array}{l}\text { CT/PT } \\
\text { Ratio }\end{array}$ & $\begin{array}{l}\text { Model or } \\
\text { Serial No. }\end{array}$ & B Relay Characteristics & Relay Settings & Remarks \\
\hline $\begin{array}{l}19 \\
20 \\
21 \\
22 \\
23\end{array}$ & $\begin{array}{l}\text { Relay Numbers } \\
\text { Are No Longer Used }\end{array}$ & & & & & - & & \\
\hline 24 & $\begin{array}{c}\text { 230-kV Carrier } \\
\text { Auxiliary Relay } \\
\text { A-388 }\end{array}$ & $85-88$ & $\begin{array}{l}\text { G.E. } \\
B C A\end{array}$ & - & [2BCAIIAVZA & $\begin{array}{l}\text { I2SV DC, R-RH-MX-GD2X } \\
\text { Units, R Coil 300mA, } \\
\text { Target }=1.0 \mathrm{~A}\end{array}$ & $\begin{array}{l}\text { Relay has been removed } \\
\text { from service as part of } \\
\text { CENRTC Project \#2F3EOA }\end{array}$ & $\begin{array}{l}\text { Relay is no longer in } \\
\text { service. }\end{array}$ \\
\hline $\begin{array}{l}25 \\
26\end{array}$ & $\begin{array}{c}\text { Relay Numbers } \\
\text { Are No Longer Used }\end{array}$ & & & & & & & \\
\hline 27 & $\begin{array}{c}\text { 230-kV Carrier } \\
\text { Auxiliary Relay } \\
\text { A-388 }\end{array}$ & $85 X-88$ & $\begin{array}{l}\text { G.E. } \\
\text { NAA }\end{array}$ & - & I2NAA22LIZA & $\begin{array}{l}\text { 125V DC, RA Coil } \\
300 \mathrm{~mA} \text {. }\end{array}$ & $\begin{array}{l}\text { Relay has been removed } \\
\text { from service as part of } \\
\text { CENRTC Project \#2F3EOA }\end{array}$ & $\begin{array}{l}\text { Relay is no longer in } \\
\text { service. }\end{array}$ \\
\hline 28 & $\begin{array}{l}\text { Hot Line Supervising Relay } \\
\text { A-382 }\end{array}$ & HL-82 & $\begin{array}{l}\text { G.E. } \\
\text { NGV }\end{array}$ & $2000 / 1 Y$ & I2NGYI3AIBA & $\begin{array}{l}\text { I20VAC, Drop-0ut 60-90V } \\
\text { Pick-Up is less than } \\
110 \% \text { of Drop-Out Volts. }\end{array}$ & $\begin{array}{l}\text { Pick-UP }=99 \mathrm{VAC} \\
\text { Drop-Out }=90 \mathrm{VAC}\end{array}$ & \\
\hline 29 & $\begin{array}{l}\text { Hot Line Supervising Relay } \\
\text { A-386 }\end{array}$ & HL-86 & $\begin{array}{l}\text { G.E. } \\
\text { NGY }\end{array}$ & $2000 / 1 \mathrm{~V}$ & I2NGV|3AIBA & $\begin{array}{l}\text { I20V AC, Drop-0ut 60-20V } \\
\text { Pick-Up is Less than } \\
110 \% \text { of Drop-0ut Volts. }\end{array}$ & $\begin{array}{l}\text { Pick-UP }=99 \mathrm{VAC} \\
\text { Drop-0ut }=90 \mathrm{~V} \text { AC }\end{array}$ & \\
\hline 30 & $\begin{array}{l}\text { Hot line Supervising Relay } \\
\text { A-388 }\end{array}$ & HL-88 & $\begin{array}{l}\text { G.E. } \\
\text { NGV }\end{array}$ & $2000 / 1 \mathrm{~V}$ & |2NGV|3AIBA & $\begin{array}{l}\text { I20V AC, Drop-0ut 60-90Y } \\
\text { Pick-Up is Less than } \\
110 \% \text { of Drop-Out Volts. }\end{array}$ & $\begin{array}{l}\text { Relay has been removed } \\
\text { from service as part of } \\
\text { CENRTC Project \#2F3EOA }\end{array}$ & $\begin{array}{l}\text { Relay is no longer in } \\
\text { service. }\end{array}$ \\
\hline 31 & $\begin{array}{l}\text { Synch. Check } \\
\text { Relay A-382 }\end{array}$ & 82-Sync & $\begin{array}{c}\text { W. } \\
\text { CVE-I }\end{array}$ & $2000 / 14$ & $292 B 353 A 34$ & $\begin{array}{l}\text { 120V, 20-40-60 Degree } \\
\text { Closing Angle Adjustment, } \\
\text { ICS = 0.2A, SPST-CC, } \\
\text { Adjusstable Closing Time. }\end{array}$ & $\begin{array}{l}\text { Closing Angle }=40 \text { Degrees } \\
\text { T.L. }=0.5 \text { to close the contact } \\
0.5 \text { sec. with } 0 \text { degree angie diff. }\end{array}$ & : \\
\hline 32 & $\begin{array}{l}\text { Synch. Check } \\
\text { Relay A-384 }\end{array}$ & 84-Sync & $\begin{array}{l}\text { W. } \\
\text { CVE-I }\end{array}$ & $2000 / 1 \%$ & $292 B 353 \mathrm{~A} 34$ & $\begin{array}{l}\text { I20Y, 20-40-60 Degree } \\
\text { Closing Angle Adjustment, } \\
\text { ICS = 0.2A, SPST-CC, } \\
\text { Adjustable Closing Time. }\end{array}$ & $\begin{array}{l}\text { Closing Angle }=40 \text { Degrees } \\
\text { T.L. }=0.5 \text { to close the contact } \\
0.5 \text { sec., with } 0 \text { degree angle diff. }\end{array}$ & \\
\hline
\end{tabular}




\section{SUBSTATION A-8}

\begin{tabular}{|c|c|c|c|c|c|c|c|c|}
\hline $\mathrm{No}$ & WWW Service & Relay 4 abel & Rejay & Patio & $\begin{array}{l}\text { Model or } \\
\text { Serial No. }\end{array}$ & Welay Characteristics & Welay Settings $\mathrm{W}$ W & Whemàrks \\
\hline 33 & $\begin{array}{l}\text { Synch. Check } \\
\text { Relay A-386 }\end{array}$ & 86-Sync & $\begin{array}{c}\text { W. } \\
\text { CVE-I }\end{array}$ & $2000 / \mathrm{IV}$ & $292 \mathrm{~B} 353 \mathrm{~A} 34$ & $\begin{array}{l}\text { I2OV, 20-40-60 Degree } \\
\text { Closing Angle Adjustment, } \\
\text { ICS = 0.2A, SPST-CC, } \\
\text { Adjustable Closing Time. }\end{array}$ & $\begin{array}{l}\text { Closing Angle }=40 \text { Degrees } \\
\text { T.L. }=0.5 \text { to close the contact } \\
0.5 \text { sec, with } 0 \text { degree angle diff. }\end{array}$ & \\
\hline 34 & $\begin{array}{l}\text { Synch. Check } \\
\text { Relay A-388 }\end{array}$ & 88-Sync & $\begin{array}{c}\text { W. } \\
\text { CVE-I }\end{array}$ & $2000 / 14$ & $292 B 353 A 34$ & $\begin{array}{l}\text { 120V, 20-40-60 Degree } \\
\text { Closing Angle Adjustment, } \\
\text { ICS = 0.2A, SPST-CC, } \\
\text { Adjustable Closing Time. }\end{array}$ & $\begin{array}{l}\text { Relay has been removed } \\
\text { from service as part of } \\
\text { CENRTC Project \#2F3E0A }\end{array}$ & $\begin{array}{l}\text { Relay is no longer in } \\
\text { service. }\end{array}$ \\
\hline .35 & $\begin{array}{l}\text { Breaker Failure } \\
\text { Relay A-382 }\end{array}$ & BFR-82 & $\begin{array}{l}\text { W. } \\
\text { SBF-I }\end{array}$ & $\begin{array}{l}1200-5 A \\
\text { Conn. } \\
800-5 A\end{array}$ & I529F93A05 & $\begin{array}{c}\text { B.F. Timer }=25-175 \mathrm{~ms} \\
\text { Control Timer }=150-250 \mathrm{~ms} \\
\text { Phase } 0 / \mathrm{C}=0.5-13.5 \mathrm{~A} \\
\text { Ground } 0 / \mathrm{C}=0.5-13.5 \mathrm{~A} \\
\text { Target and Seal-in }=0.2 / 2.0 \mathrm{~A}\end{array}$ & $\begin{array}{c}\text { B.F. Timer }=133 \mathrm{~ms} \\
\text { Control Timer }=166 \mathrm{~ms} \\
\text { Phase } 0 / C=0.5 \mathrm{~A} \\
\text { Ground } 0 / \mathrm{C}=0.5 \mathrm{~A} \\
\text { Target and Seal. }-\mathrm{ln}=0.2 \mathrm{~A}\end{array}$ & $\therefore$ \\
\hline 36 & $\begin{array}{l}\text { Breaker Failure } \\
\text { Relay A-384 }\end{array}$ & BFR-84 & \begin{tabular}{|c|} 
W. \\
SBF-I
\end{tabular} & $\begin{array}{l}1200-5 A \\
\text { Conn. } \\
800-5 A\end{array}$ & $1529 \mathrm{~F} 93 \mathrm{A05}$ & $\begin{array}{c}\text { B.F. Timer }=25-175 \mathrm{~ms} \\
\text { Control Timer }=150-250 \mathrm{~ms} \\
\text { Phase } 0 / \mathrm{C}=0.5-13.5 \mathrm{~A} \\
\text { Ground } 0 / \mathrm{C}=0.5-13.5 \mathrm{~A} \\
\text { Target and Seal- } \mathrm{In}=0.2 / 2.0 \mathrm{~A}\end{array}$ & $\begin{array}{c}\text { B.F. Timer }=133 \mathrm{~ms} \\
\text { Control Timer }=166 \mathrm{~ms} \\
\text { Phase } 0 / C=0.5 \mathrm{~A} \\
\text { Ground } 0 / C=0.5 \mathrm{~A} \\
\text { Target and Seal }-\mathrm{ln}=0.2 \mathrm{~A}\end{array}$ & \\
\hline 37 & $\begin{array}{l}\text { Breaker Failure } \\
\text { Relay A-386 }\end{array}$ & BFR-86 & $\begin{array}{l}\text { W. } \\
\text { SBF-I }\end{array}$ & $\begin{array}{c}1200-5 \mathrm{~A} \\
\text { Conn. } \\
800-5 \mathrm{~A}\end{array}$ & $1529 F 93 A 05$ & $\begin{array}{c}\text { B.F. Timer }=25-175 \mathrm{~ms} \\
\text { Control Timer }=150-250 \mathrm{~ms} \\
\text { Phase } 0 / \mathrm{C}=0.5-13.5 \mathrm{~A} \\
\text { Ground } 0 / \mathrm{C}=0.5-13.5 \mathrm{~A} \\
\text { Target and Seal- } \mathrm{In}=0.2 / 2.0 \mathrm{~A}\end{array}$ & $\begin{array}{c}\text { B.F. Timer }=133 \mathrm{~ms} \\
\text { Control Timer }=166 \mathrm{~ms} \\
\text { Phase } 0 / \mathrm{C}=0.5 \mathrm{~A} \\
\text { Ground } 0 / C=0.5 \mathrm{~A} \\
\text { Target and Seal- } \ln =0.2 \mathrm{~A}\end{array}$ & \\
\hline 38 & $\begin{array}{l}\text { Breaker Failure } \\
\text { Relay A-388 }\end{array}$ & BFR-88 & $\begin{array}{l}\text { W. } \\
\text { SBF-I }\end{array}$ & $\begin{array}{c}1200-5 A \\
\text { Conn. } \\
800-5 A\end{array}$ & $1529593 \mathrm{A05}$ & $\begin{array}{c}\text { B.F. Timer }=18-175 \mathrm{~ms} \\
\text { Control Timer }=150.250 \mathrm{~ms} \\
\text { Phase } 0 / C=0.5-13.5 \mathrm{~A} \\
\text { Ground } 0 / C=0.5-13.5 \mathrm{~A} \\
\text { Target and Seal- }-\mathrm{In}=0.22 .0 \mathrm{~A}\end{array}$ & $\begin{array}{c}\text { B.F. Timer }=133 \mathrm{~ms} \\
\text { Control Timer }=166 \mathrm{~ms} \\
\text { Phase } 0 / C=0.5 \mathrm{~A} \\
\text { Ground } 0 / C=0.5 \mathrm{~A} \\
\text { Target and Seal-In }=0.2 \mathrm{~A}\end{array}$ & \\
\hline 39 & $\begin{array}{l}\text { 230-kV Backup } \\
\text { Ground Relay } \\
\text { A-382 }\end{array}$ & $67 G B-82$ & $\begin{array}{l}\text { G.E. } \\
J B C G\end{array}$ & $\begin{array}{l}1200-5 \mathrm{~A} \\
\text { Conn. } \\
800-5 \mathrm{~A} \\
1150-1 \mathrm{~W}\end{array}$ & $12 \mathrm{jBCG} 33 \mathrm{KIIY}$ & $\begin{array}{c}\text { Time } 0 / C=1.5-6.0 \mathrm{~A} \\
\text { Dir. Inst. } 0 / \mathrm{C}=10-40 \mathrm{~A} \\
\text { Non-Dir. Inst. } 0 / \mathrm{C}=2-8 \mathrm{~A} \\
\text { Max Torque Angle }=60 \text { Degree } \\
\text { Target and Seal-In }=0.2 / 2.0 \mathrm{~A}\end{array}$ & $\begin{array}{c}\mathrm{J} / 0 / \mathrm{C} \text { Tap }=4 \mathrm{~A}, \mathrm{TD}=3.0 \\
\text { Dir. Inst. } 0 / \mathrm{C}=21 \mathrm{~A} \\
\text { Non-Dir. Inst. } 0 / \mathrm{C}=4.0 \mathrm{~A} \\
\text { Max Torque Angle }=60 \text { Degree } \\
\text { Target and Seal-ln }=2.0 \mathrm{~A}\end{array}$ & \\
\hline
\end{tabular}




\section{SUBSTATION A-8}

\begin{tabular}{|c|c|c|c|c|c|c|c|c|}
\hline No & Whymp & Relaylabel & $\begin{array}{l}\text { Relay, } \\
\text { Type }\end{array}$ & $\begin{array}{l}\text { OT/PT } \\
\text { Ratio }\end{array}$ & $\begin{array}{l}\text { Model or } \\
\text { Serial No. }\end{array}$ & W\% Relay Characteristics & Whelay Settings & Remarks \\
\hline 40 & $\begin{array}{c}\text { 230-kV Backup } \\
\text { Ground Relay } \\
\text { A-386 }\end{array}$ & $67 G B-86$ & $\begin{array}{l}\text { G.E. } \\
\mathrm{JBCG}\end{array}$ & $\begin{array}{l}1200-5 A \\
\text { Conn. } \\
800-5 A \\
\text { IISO-IV }\end{array}$ & I2]BCGS3KIIY & $\begin{array}{c}\text { Time } 0 / C=1.5-6.0 \mathrm{~A} \\
\text { Dir. Inst. } 0 / C=10-40 \mathrm{~A} \\
\text { Non-Dir. Inst. } 0 / \mathrm{C}=2-8 \mathrm{~A} \\
\text { Max Torque Angle }=60 \text { Degree } \\
\text { Target and Seal-In }=0.2 / 2.0 \mathrm{~A}\end{array}$ & $\begin{array}{c}\mathrm{T} / 0 / \mathrm{C} \text { Tap }=4 \mathrm{~A}, \mathrm{ID}=3.0 \\
\text { Dir. Inst. } 0 / \mathrm{C}=2 \mathrm{IA} \\
\text { Non-Dir. Inst. } 0 / \mathrm{C}=4.0 \mathrm{~A} \\
\text { Max Torque Angle }=60 \text { Degree } \\
\text { Target and Seal-ln }=2.0 \mathrm{~A}\end{array}$ & \\
\hline 41 & $\begin{array}{l}\text { 230-kV Backup } \\
\text { Ground Relay } \\
\text { A-388 }\end{array}$ & $676 B-8 B$ & $\begin{array}{l}\text { G.E. } \\
J B C G\end{array}$ & $\begin{array}{l}1200-5 A \\
\text { Conn. } \\
800-5 A \\
1150-17\end{array}$ & $\begin{array}{c}\text { 12]BCG53M4Y } \\
\text { IA }\end{array}$ & $\begin{array}{c}\text { Time } 0 / \mathrm{C}=1.5-6.0 \mathrm{~A} \\
\text { Dir. Inst. } 0 / \mathrm{C}=2.8 \mathrm{~A} \\
\text { Non-Dir. Inst. } 0 / \mathrm{C}=6-150 \mathrm{~A} \\
\text { Max Torquue Angle }=60 \text { Degree } \\
\text { Target and SeaI-In }=0.2 / 2.0 \mathrm{~A}\end{array}$ & $\begin{array}{l}\text { Relay has been removed } \\
\text { from service as part of } \\
\text { CENRTC Project \#2E3EOA }\end{array}$ & $\begin{array}{l}\text { Relay is no longer in } \\
\text { service. }\end{array}$ \\
\hline $\begin{array}{l}42 \\
43 \\
\end{array}$ & $\begin{array}{l}\text { Relay Numbers } \\
\text { Are No Longer Used }\end{array}$ & & & & & & & \\
\hline 44 & $\begin{array}{c}\text { 230-kV Carrier } \\
\text { Ground Relay } \\
\text { A-388 }\end{array}$ & $67 \mathrm{G}-88$ & $\begin{array}{l}\text { G.E. } \\
\text { CLPG }\end{array}$ & $\begin{array}{l}1200-5 A \\
\text { Conn. } \\
800-5 A \\
1150-I V\end{array}$ & $12 C L P G|2 C| 9 A$ & $\begin{array}{c}\mathrm{GI}=.8-3.2 \mathrm{~A}, \mathrm{G} 2=1-4 \mathrm{~A} / 2-8 \mathrm{~A} \\
\mathrm{GD}=3.6-57.6 \mathrm{VA} \\
\text { Max Torque Angle }=80 \text { Degree } \\
\text { Seal- }-\mathrm{ln}=2.0 \mathrm{~A} \\
\text { Target }=1.0 \mathrm{~A}\end{array}$ & $\begin{array}{l}\text { Relay has been removed } \\
\text { from service as part of } \\
\text { CENRTC Project \#2F3EOA }\end{array}$ & $\begin{array}{l}\text { Relay is no longer in } \\
\text { service. }\end{array}$ \\
\hline 45 & $\begin{array}{c}\text { Relay Number Is No Longer } \\
\text { Used }\end{array}$ & & & & & & & \\
\hline $\begin{array}{l}46 \\
47 \\
48\end{array}$ & $\begin{array}{l}\text { 230-kY Bus No. I } \\
\text { Diff. Relays }\end{array}$ & 87BI-TH-A-B-C & $\begin{array}{l}\text { G.E. } \\
\text { PVD }\end{array}$ & 1200.5 & |2PYD2IB|A & $\begin{array}{l}120 \mathrm{~V}, 60 \mathrm{~Hz}, 87 \mathrm{~L}=75-500 \mathrm{~V}, \\
.87 \mathrm{H}=2-50 \mathrm{~A}, \text { Single-Phase, } \\
\text { Target and Seal-In }=0.22 .0 \mathrm{~A}\end{array}$ & $\begin{array}{c}87 \mathrm{~L}=200 \text { Volts } \\
87 \mathrm{H}=2.0 \mathrm{~A} \\
\text { Target and Seal-In }=0.2 \mathrm{~A} \\
87 \mathrm{~L} \text { on High Tap } \\
87 \text { H on Low Tap }\end{array}$ & \\
\hline $\begin{array}{l}49 \\
50 \\
51\end{array}$ & $\begin{array}{l}\text { 230-kV Bus No. } 2 \\
\text { Diff. Relays }\end{array}$ & 87B2-ТН-A-B-C & $\begin{array}{l}\text { G.E. } \\
\text { PVD }\end{array}$ & $1200-5$ & I2PVD2IBIA & $\begin{array}{l}120 \mathrm{~V}, 60 \mathrm{~Hz}, 87 \mathrm{~L}=75-500 \mathrm{~V} \\
87 \mathrm{H}=2-50 \mathrm{~A}, \text { Single-Phase, } \\
\text { Target and Seal-In }=0.2 / 2.0 \mathrm{~A}\end{array}$ & $\begin{array}{c}87 \mathrm{~L}=200 \mathrm{Vol} \text { lis } \\
87 \mathrm{H}=2.0 \mathrm{~A} \\
\text { Target and Seal-In }=0.2 \mathrm{~A} \\
87 \mathrm{~L} \text { on High Tap } \\
87 \mathrm{H} \text { on Low Tap }\end{array}$ & : \\
\hline $\begin{array}{l}52 \\
53 \\
54\end{array}$ & $\begin{array}{l}\text { 230.kV Bank No. I } \\
\text { Diff. Relays }\end{array}$ & 87TLI-A-B-C & $\begin{array}{l}\text { W. } \\
\text { HU-I }\end{array}$ & $\begin{array}{c}600-5 \\
400 \text { A H.Y. } \\
2000-5 \text { L.Y. }\end{array}$ & 290B346Al0 & $\begin{array}{c}\text { Three Winding Restraints, } \\
2.9-8.7 \mathrm{~A} \text { Taps, } \\
30 \% \text { Slope } \\
\text { Non-Adjustable [Slope] } \\
\text { Target and Seal-In }=0.2 / 2.0 \mathrm{~A}\end{array}$ & $\begin{array}{c}\text { H.Y. Tap }=4.6 \mathrm{~A}[\text { Bottom Block }] \\
\text { L.Y. Tap }=8.7 \mathrm{~A} \\
\text { [Top and Middle Blocks] } \\
30 \% \text { Slope } \\
\text { Target and Seal-lo }=0.2 \mathrm{~A}\end{array}$ & $\begin{array}{l}\text { Replaced 4mF Cap. } \\
\text { Cph. Out. } \\
\text { Then Replaced Relay Out. }\end{array}$ \\
\hline
\end{tabular}




\section{SUBSTATION A-8}

\begin{tabular}{|c|c|c|c|c|c|c|c|c|}
\hline No & 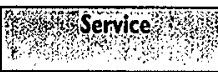 & Relay Label & $\begin{array}{l}\text { Relay } \\
\text { Type }\end{array}$ & $\begin{array}{l}\text { Cr/PT } \\
\text { Ratio }\end{array}$ & $\begin{array}{l}\text { Model or } \\
\text { Serial No. }\end{array}$ & Wh Relay Characteristics & Relay Settings & Remarks \\
\hline $\begin{array}{l}55 \\
56 \\
57\end{array}$ & $\begin{array}{c}230-k V \text { Bank No. } 2 \\
\text { Diff. Relays }\end{array}$ & $87 T L 2-A-B-C$ & $\begin{array}{c}\text { W. } \\
\text { HU-I }\end{array}$ & $\begin{array}{c}600-5 \\
400 A \\
\text { H.Y. } \\
2000-5 \\
\text { L.Y. }\end{array}$ & 2908346A10 & $\begin{array}{c}\text { Three Winding Restraints, } \\
2.9-8.7 \mathrm{~A} \text { Taps, } \\
30 \% \text { Slope } \\
\text { Non-Adjustable [Slope] } \\
\text { Target and Seal-In }=0.22 .0 \mathrm{~A}\end{array}$ & $\begin{array}{c}\text { H.V. Tap }=4.6 \mathrm{~A}[\text { Bottom Block] } \\
\text { L.Y. Tap }=8.7 \mathrm{~A} \\
\text { [Top and Middle Blocks] } \\
30 \% \text { Slope } \\
\text { Target and Seal-In }=0.2 \mathrm{~A}\end{array}$ & \\
\hline $\begin{array}{l}58 \\
59 \\
60\end{array}$ & $\begin{array}{c}230-\mathrm{kV} \text { Bank No. I } \\
\text { O/C. Relays }\end{array}$ & $50 / 51-T H I-A-B-C$ & $\begin{array}{l}\text { W. } \\
\text { C0-9 }\end{array}$ & $800-5$ & $264 C 901403$ & $\begin{array}{l}\text { Time } 0 / C=0.5-2.5 \mathrm{~A} \\
\text { Inst. } 0 / C=2.0-48 \mathrm{~A}\end{array}$ & $\begin{aligned} \text { Tap } & =1 \mathrm{~A} \\
\mathrm{~T} . \mathrm{D} . & =8 \\
\text { Inst. } & =6 \mathrm{~A}\end{aligned}$ & 1.7 seconds@6A \\
\hline $\begin{array}{l}61 \\
62 \\
63 \\
\end{array}$ & $\begin{array}{c}230-\mathrm{kV} \text { Bank No. } 2 \\
\text { O/C. Relays }\end{array}$ & $50 / 51-T H 2-A-B-C$ & $\begin{array}{l}\text { W. } \\
60-9\end{array}$ & $800-5$ & $264 C 901403$ & $\begin{array}{l}\text { Time } 0 / C=0.5-2.5 \mathrm{~A} \\
\text { Inst. } 0 / \mathrm{C}=2.0-48 \mathrm{~A}\end{array}$ & $\begin{aligned} \text { Tap } & =\mathrm{IA} \\
\text { T.D. } & =8 \\
\text { Inst. } & =6 \mathrm{~A}\end{aligned}$ & I.7 seconds@6A \\
\hline 64 & $\begin{array}{c}\text { Auto-Reclosing Relay } \\
\text { A-382 }\end{array}$ & $79-82$ & $\begin{array}{l}\text { G.E. } \\
\text { AC-I }\end{array}$ & - & $607060 I-G I R$ & & $\begin{array}{l}\text { Single-shot reclosing } \\
\text { after } 6.0 \text { seconds. }\end{array}$ & \\
\hline 65 & $\begin{array}{c}\text { Auto-Reclosing Relay } \\
A-386\end{array}$ & 79.86 & $\begin{array}{l}\text { G.E. } \\
A C-I\end{array}$ & - & $6070601-G \mid R$ & . & $\begin{array}{l}\text { Single-shot reclosing } \\
\text { after } 6.0 \text { seconds. }\end{array}$ & \\
\hline 66 & $\begin{array}{c}\text { Auto-Reclosing Relay } \\
\text { A-388 }\end{array}$ & $79-88$ & $\begin{array}{l}\text { G.E. } \\
\text { NER }\end{array}$ & - & & & $\begin{array}{l}\text { Relay has been removed } \\
\text { from service as part of } \\
\text { CENRTC Project \#2E3EOA }\end{array}$ & $\begin{array}{l}\text { Relay is no longer in } \\
\text { service. }\end{array}$ \\
\hline 67 & $\begin{array}{l}\text { 230-kV Bank Mo.I } \\
\text { Neutral O/C. Relay }\end{array}$ & 5IG-IHI & $\begin{array}{l}\text { G.E. } \\
\text { IAC }\end{array}$ & $600-5$ & $121 \mathrm{AC53B803A}$ & $\begin{array}{l}\text { Time } 0 / \mathrm{C}=0.5-4.0 \mathrm{~A} \\
\text { Inst. } 0 / \mathrm{C}=2.0-16 \mathrm{~A}\end{array}$ & $\begin{array}{c}\text { Time } 0 / C \text { Tap }=2.0 \mathrm{~A} \\
\text { T.L. =3 } \\
\text { Inst. } 0 / \mathrm{C}=\text { Blocked. }\end{array}$ & 0.62 Seconds@12A \\
\hline 68 & $\begin{array}{l}\text { 230-kV Bank No.2 } \\
\text { Neutral O/C. Relay }\end{array}$ & $5 \mid \mathrm{G}$-TH2 & $\begin{array}{l}\text { G.E. } \\
\text { IAC }\end{array}$ & $600-5$ & 12LAC53B803A & $\begin{array}{l}\text { Time } 0 / \mathrm{C}=0.5-4.0 \mathrm{~A} \\
\text { lnst. } 0 / \mathrm{C}=2.0-16 \mathrm{~A}\end{array}$ & $\begin{array}{c}\text { Time } 0 / C \text { Tap }=2.0 \mathrm{~A} \\
\text { T.L. }=3 \\
\text { Inst. } 0 / \mathrm{C}=\text { Blocked. }\end{array}$ & 0.62 Seconds @ I2A \\
\hline 69 & $\begin{array}{c}\text { Zig-lag Grounding Bank } \\
\text { Neutral O/C Alarm Relay } \\
\text { Bank Ho.1 }\end{array}$ & 50G-GTI & $\begin{array}{l}\text { G.E. } \\
\text { PJC }\end{array}$ & $600-5$ & IZPJCIIDIR & Inst. $0 / C=0.5-2.0 \mathrm{~A}$ & $\begin{array}{c}\text { Inst }=0.5 \mathrm{~A} \\
60 \text { Amps Primary } \\
\text { Alarm Only }\end{array}$ & \\
\hline $\begin{array}{c}600 \\
-5 \\
\end{array}$ & $\begin{array}{c}\text { lig-lag Grounding Bank } \\
\text { Neutral O/C Alarm Relay } \\
\text { Bank Mo.2 }\end{array}$ & 50G.GR & $\begin{array}{l}\text { G.E. } \\
\text { PJC }\end{array}$ & & I2PJCIIEIA & Inst. $0 / \mathrm{C}=0.5-2.0 \mathrm{~A}$ & $\begin{array}{c}\text { lnst }=0.5 A \\
60 \text { Amps Primary } \\
\text { Alarm Only }\end{array}$ & \\
\hline
\end{tabular}




\section{SUBSTATION A-8}

\begin{tabular}{|c|c|c|c|c|c|c|c|c|}
\hline No & Whenvice & Relay Label & $\begin{array}{l}\text { Relay } \\
\text { Type }\end{array}$ & $\begin{array}{l}\mathrm{CT} / \mathrm{PT} \\
\text { Ratio }\end{array}$ & $\begin{array}{l}\text { Model or } \\
\text { Serial No. }\end{array}$ & Whelay Characteristics & Relay Settings & Remarks \\
\hline $\begin{array}{c}400 \\
-5\end{array}$ & $\begin{array}{c}\text { Zig.lag Grounding } \\
\text { Bank 0/C Relays } \\
\text { Bank No.I }\end{array}$ & SI-GTI-A-B-C & $\begin{array}{l}\text { G.E. } \\
\text { IAC }\end{array}$ & & 121AC53B2R & $\begin{array}{c}\text { Time } 0 / \mathrm{C}=1.5-6.0 \mathrm{~A} \\
\text { Target and Seal-in }=0.2 / 2.0 \mathrm{~A}\end{array}$ & $\begin{array}{c}\text { Tap }=4.0 \mathrm{~A} \\
\text { T.D. }=2 \\
\text { Target and Seal- } \mathrm{ln}=0.2 \mathrm{~A} \\
\text { No Inst. Setting }\end{array}$ & $0.3 \mathrm{Sec} @ 40 \mathrm{~A}$ \\
\hline $\begin{array}{l}74 \\
75 \\
76\end{array}$ & $\begin{array}{c}\text { Zig-lag Grounding } \\
\text { Bank 0/C Relays } \\
\text { Bank No.2 }\end{array}$ & $51-G T 2-A-B-C$ & $\begin{array}{l}\text { G.E. } \\
\text { IAC }\end{array}$ & $400-5$ & I21ACS3BIA & $\begin{array}{c}\text { Time } 0 / \mathrm{C}=4.0-16 \mathrm{~A} \\
\text { Target and Seal-ln }=0.2 / 2.0 \mathrm{~A}\end{array}$ & $\begin{array}{c}\text { Tap }=4.0 \mathrm{~A} \\
\text { T.D. }=2 \\
\text { Target and Seal-ln }=0.2 \mathrm{~A} \\
\text { Inst }=\text { Blocked }\end{array}$ & 0.42 Seconds @ 24A \\
\hline 77 & $\begin{array}{c}\text { Zig-lag Grounding } \\
\text { Bank Neutral 0/C Relay } \\
\text { Bank No. I }\end{array}$ & SIGB.GII & $\begin{array}{l}\text { G.E. } \\
\text { IAC }\end{array}$ & $\begin{array}{c}1200-5 \\
600 A\end{array}$ & 121AC778803A & $\begin{array}{c}\text { Time } 0 / \mathrm{C}=0.5 .4 .0 \mathrm{~A} \\
\text { Target and Seal- } \mathrm{In}=0.2 / 2.0 \mathrm{~A}\end{array}$ & $\begin{array}{c}\text { Tap }=2.5 \mathrm{~A} \\
\text { T.D. }=10 \\
\text { Target and Seal-In }=0.2 \mathrm{~A}\end{array}$ & 17 Seconds@SA \\
\hline 78 & $\begin{array}{c}\text { lig-lag Grounding } \\
\text { Bank Neutral } 0 / C \text { Relay } \\
\text { Bank No.2 }\end{array}$ & $5 \mid G B-G T 2$ & $\begin{array}{l}\text { G.E. } \\
\text { IAC }\end{array}$ & $\begin{array}{c}1200-5 \\
600 A\end{array}$ & 121AC77B803A & $\begin{array}{c}\text { Time } 0 / \mathrm{C}=0.5 \cdot 4.0 \mathrm{~A} \\
\text { Target and Seal- } \mathrm{In}=0.22 .0 \mathrm{~A}\end{array}$ & $\begin{array}{c}\text { Tap }=2.5 \mathrm{~A} \\
\text { T.D. }=10 \\
\text { Target and Seal- }-\mathrm{ln}=0.2 \mathrm{~A}\end{array}$ & 17 Seconds@5A \\
\hline 79 & Sudden Pressure & & & & & & & \\
\hline
\end{tabular}


SUBSTATION B3-54

\section{AREA}

\begin{tabular}{|c|c|c|c|c|c|c|c|c|}
\hline $\mathrm{No}$ & Wervicents & Relay & Relay & CT/PT & $\begin{array}{l}\text { Modelion: } \\
\text { Style No }\end{array}$ & Welay Characteristics & Whelay Settings th & Remarks \\
\hline $\begin{array}{l}1 \\
2 \\
3\end{array}$ & $\begin{array}{l}\| 15-k V \text { Back-Up } \\
\text { Line Relays } \\
\text { Benton BIII6 }\end{array}$ & \begin{tabular}{c|}
$2 \mathrm{I}-$ \\
$\mathrm{B}-2 \mathrm{~B}-$ \\
3B-BEN
\end{tabular} & $\begin{array}{l}\text { G.E. } \\
\text { SLY }\end{array}$ & $\begin{array}{l}1200-5 \\
1000 / 14\end{array}$ & $\begin{array}{l}\text { I2SLYY8IA2D } \\
\text { 12SLY8IA2D } \\
\text { 12SLY8IA4D }\end{array}$ & $\begin{array}{l}20 \text { MHO Unit }=0.1-40 \mathrm{hm} \\
40 \text { MHO Unit }=0.75-300 \mathrm{hm} \\
\text { Max Torque Angle }=85 \text { Degree } \\
\text { Target and Seal- }-\mathrm{In}=0.6 / 2.0 \mathrm{~A}\end{array}$ & $\begin{array}{l}\text { Ist Zone }=1.030 \mathrm{hm}, 39 \% \text { Tap } \\
\text { 2nd Zone }=1.670 \mathrm{hm}, 23 \% \text { Tap } \\
\text { 3rd Zone }=26.40 \mathrm{hm}, 11 \% \text { Tap } \\
\text { Max Torque Angle }=85 \text { Degree } \\
\text { Target and Seal- }-\mathrm{ln}=2.0 \mathrm{~A}\end{array}$ & $\begin{array}{c}\text { Min. Reach Taps } \\
0.40 \mathrm{hm} \text { [IB-2B Units] } \\
3.00 \mathrm{hm}[3 \mathrm{~B}-\text { Unit] }\end{array}$ \\
\hline $\begin{array}{l}4 \\
5 \\
6\end{array}$ & $\begin{array}{l}\text { UIS-kV Back-Up } \\
\text { Line Relays } \\
\text { W.B.B II07 }\end{array}$ & \begin{tabular}{|c|}
$2 \mid-$ \\
$\mid B-28-$ \\
$3 B-$ \\
W.B.
\end{tabular} & $\begin{array}{l}\text { G.E. } \\
\text { SLY }\end{array}$ & $\begin{array}{c}1200-5 \\
1000 / 1 V\end{array}$ & $\begin{array}{l}\text { 12SLY8IA2D } \\
\text { I2SLY8IA2D } \\
\text { I2SLY8IA4D }\end{array}$ & $\begin{array}{l}\text { 2D MHO Unit }=0.1-40 \mathrm{hm} \\
\text { 4D MHO Unit }=0.75-30 \mathrm{Ohm} \\
\text { Max Torque Angle }=85 \text { Degree } \\
\text { Target and Seal- }-\mathrm{g}=0.6 / 2.0 \mathrm{~A}\end{array}$ & $\begin{array}{l}\text { Ist Zone }=1.030 \mathrm{hm}, 55 \% \text { Tap } \\
\text { 2nd Zone }=1.6720 \mathrm{hm}, 27 \% \text { Tap } \\
\text { 3rd Zone }=5.580 \mathrm{hm}, 49 \% \text { Tap } \\
\text { Max Torque Angle }=85 \text { Degree } \\
\text { Target and Seal-In }=2.0 \mathrm{~A}\end{array}$ & $\begin{array}{c}\text { Min. Reach Taps } \\
0.40 \mathrm{hm} \text { [ [B-28 Units] } \\
3.00 \mathrm{hm} \text { [3B-Unit] }\end{array}$ \\
\hline $\begin{array}{c}7 \\
9 \\
11\end{array}$ & $\begin{array}{l}\text { IIS-kV Primary } \\
\text { Line Relays } \\
\text { Benton BIII6 }\end{array}$ & \begin{tabular}{|l|} 
2I- \\
IP-2P- \\
3P-BEN
\end{tabular} & $\begin{array}{l}\text { G.E. } \\
\text { CEY }\end{array}$ & $\begin{array}{c}1200-5 \\
1000 / 1 V\end{array}$ & $\begin{array}{l}\text { I2CEYSIA3D } \\
\text { I2CEYSZA3D } \\
\text { 12CEY52A2D }\end{array}$ & $\begin{array}{l}\text { 5IA3D MHO Unit }=.375-150 \mathrm{hm} \\
52 \mathrm{AD} \text { MHO Unit }=5.150 \mathrm{hm} \\
52 \mathrm{A20} \text { MHO Unit }=1-30 \mathrm{Ohm} \\
\text { Max Torque Angle }=60 \text { Degree } \\
\text { Target and Seal-ln }=0.2 / 2.0 \mathrm{~A}\end{array}$ & $\begin{array}{c}\text { 15T Zone }=1.030 \mathrm{hm}, 71 \% \text { TAP } \\
\text { 2nd Zone }=1.6720 \mathrm{hm}, 88 \% \text { TAP } \\
\text { 3rd Zone }=26.40 \mathrm{hm}, 11 \% \text { TAP } \\
\text { Max Torque Angle }=60 \text { Degree } \\
\text { Target and Seal-In }=2.0 \mathrm{~A}\end{array}$ & $\begin{array}{c}\text { Min Reach } \\
0.750 \mathrm{hm} \mathrm{51-A3D} \text {; } \\
1.50 \mathrm{hm} 52 \mathrm{A3D} ; \\
30 \mathrm{hm} 52 \mathrm{A2D}\end{array}$ \\
\hline \begin{tabular}{c|}
8 \\
10 \\
12
\end{tabular} & $\begin{array}{l}\text { IIS-kV Primary } \\
\text { Line Relays } \\
\text { W.B.B BI07 }\end{array}$ & \begin{tabular}{|c|} 
2l- \\
IP-2P. \\
$3 P$. \\
W.B.
\end{tabular} & $\begin{array}{l}\text { G.E. } \\
\text { CEY }\end{array}$ & $\begin{array}{l}1200.5 \\
1000 / 14\end{array}$ & $\begin{array}{l}\text { 12CEYSIA3D } \\
\text { I2CEY52A3D } \\
\text { I2CEY52A2D }\end{array}$ & $\begin{array}{l}\text { 5IA3D MHO Unit }=.375 .150 \mathrm{hm} \\
\text { 52A3D MHO Unit }=5.150 \mathrm{hm} \\
\text { 52A2D MHO Unit }=1-300 \mathrm{hm} \\
\text { Max Torque Angle }=60 \text { Degree } \\
\text { Target and Seal- }-\mathrm{n}=0.2 / 2.0 \mathrm{~A}\end{array}$ & $\begin{array}{l}\text { IST ZONE }=0.7250 \mathrm{hm}, 49 \% \text { TAP } \\
\text { 2nd Zone }=1.457 \text { 0hm, } 99 \% \text { TAP } \\
\text { 3rd Zone }=5.580 \mathrm{hm}, 46 \% \text { TAP } \\
\text { Max Torque Angle }=60 \text { Degree } \\
\text { Target and Seal--in }=2.0 \mathrm{~A}\end{array}$ & $\begin{array}{l}\text { Min. Reach Tap } \\
0.3750 \mathrm{hm} \mathrm{S-1A3} \text {; } \\
\text { 1.5 Ohm 52A3D; } \\
30 \mathrm{hm} \mathrm{52A2D}\end{array}$ \\
\hline$B$ & $\begin{array}{c}\text { Synch. Check } \\
\text { Relay Benton BIII6 }\end{array}$ & $\begin{array}{l}\text { BEN- } \\
\text { SYNC }\end{array}$ & $\begin{array}{l}\text { G.E. } \\
\text { lJs }\end{array}$ & $1000 / \mathrm{IV}$ & $|2| \mid 55203 \mathrm{~A}$ & $\begin{array}{l}115 V, 20-30-40-60 \text {-degree } \\
\text { closing angle adjustment, } \\
\text { adjustable closing time. }\end{array}$ & $\begin{array}{c}\text { Closing Angle }=20 \text { Degree } \\
\text { T.L. }=1.0 \text { to close the contact in less than } 3 \text { seconds } \\
\text { with } 0 \text { degree angle diff. }\end{array}$ & . \\
\hline 14 & $\begin{array}{l}\text { Synch. Check } \\
\text { Relay Tie BIII3 }\end{array}$ & $\begin{array}{l}\text { TIE- } \\
\text { SYNC } \\
\end{array}$ & $\begin{array}{l}\text { G.E. } \\
\text { IJS }\end{array}$ & $1000 / 1 V$ & $121] 55203 \mathrm{~A}$ & $\begin{array}{l}\text { IISV, 20-30- 40-60-degree } \\
\text { closing angle adjustment, } \\
\text { adjustable closing time. }\end{array}$ & $\begin{array}{c}\text { Closing Angle }=20 \text { Degree } \\
\text { T.L. }=1.0 \text { to close the contact in less than } 3 \text { seconds } \\
\text { with } 0 \text { degree angle diff. }\end{array}$ & \\
\hline 15 & $\begin{array}{c}\text { Synch. Check } \\
\text { Relay W.B. BI107 }\end{array}$ & $\begin{array}{l}\text { W.B. } \\
\text { SYNC }\end{array}$ & $\begin{array}{l}\text { G.E. } \\
\text { IIs }\end{array}$ & $1000 / I V$ & $121 \int 55203 A$ & $\begin{array}{l}\text { IISV, 20-30-40-60-degree } \\
\text { closing angle adjustment, } \\
\text { adjustable closing time. }\end{array}$ & $\begin{array}{c}\text { Closing Angle }=20 \text { Degree } \\
\text { T.L. }=1.0 \text { to close the contact in less than } 3 \text { seconds } \\
\text { with } 0 \text { degree angle diff. }\end{array}$ & \\
\hline $\begin{array}{l}16 \\
18\end{array}$ & $\begin{array}{l}\text { UN Relays } \\
\text { Benton BIIl6 }\end{array}$ & $\begin{array}{l}27-1 \\
27-2 \\
\text { BEN }\end{array}$ & $\begin{array}{l}\text { G.E. } \\
\text { NGV }\end{array}$ & $1000 / \mathrm{IV}$ & |2NGVIIBISA & $\begin{array}{l}\text { 120VAC, Drop-Out } 70-100 \mathrm{~V} \\
\text { pick-up is less than } \\
110 \% \text { of drop-out volts. }\end{array}$ & $\begin{array}{l}\text { Pick-Uip }=99 \mathrm{VAC} \\
\text { DROP-OUI }=90 \mathrm{YAC}\end{array}$ & \\
\hline
\end{tabular}


SUBSTATION - B3-S4

300 AREA

\begin{tabular}{|c|c|c|c|c|c|c|c|c|}
\hline $\mathrm{No}$ & Wrive & Relay & Relay & Ratio & $\begin{array}{l}\text { Modelor } \\
\text { style No. }\end{array}$ & Welay Characteristics W & Relay Settings & Whemarks \\
\hline \begin{tabular}{l|}
17 \\
19
\end{tabular} & $\begin{array}{l}\text { UN Relays } \\
\text { W.B. Bll07 }\end{array}$ & $\begin{array}{l}27-1 \\
27.2 \\
\text { W.B. }\end{array}$ & $\begin{array}{l}\text { G.E. } \\
\text { NGY }\end{array}$ & $1000 / \mathrm{W}$ & I2NGVIIBISA & $\begin{array}{l}\text { 120Y AC, drop-out } 70-100 Y \\
\text { pick-up is less than } \\
110 \% \text { of drop-out volts. }\end{array}$ & $\begin{array}{l}\text { Pick-Up }=99 \mathrm{VAC} \\
\text { Drop-0ut }=90 \mathrm{VAC}\end{array}$ & \\
\hline 20 & $\begin{array}{c}\text { Fault Detector } \\
\text { Breaker Fail. Scheme } \\
\text { Bank-1 }\end{array}$ & $\begin{array}{l}\text { FD- } \\
\text { BFR- } \\
\text { TI }\end{array}$ & $\begin{array}{l}\text { G.E. } \\
\text { NHC }\end{array}$ & $600-5$ & IZNHCIIAIA & $\begin{array}{c}\text { 3-Phase, I.0A Fixed } \\
\text { Settings } \\
\text { Target }=0.2 / 2.0 \mathrm{~A}\end{array}$ & $\begin{array}{c}\text { 3-Phase, 1.0A Fixed } \\
\text { Settings [120A Primary] } \\
\text { Target }=0.2 \mathrm{~A}\end{array}$ & \\
\hline 21 & \begin{tabular}{|c|} 
Fault Detector \\
Breaker Fail. Scheme \\
Bank-2
\end{tabular} & $\begin{array}{l}\text { FD- } \\
\text { BFR- } \\
R\end{array}$ & $\begin{array}{l}\text { G.E. } \\
\text { NHC }\end{array}$ & & I2NHCIIAIA. & $\begin{array}{c}\text { 3-Phase, I.0A Fixed } \\
\text { Settings } \\
\text { Target }=0.2 / 2.0 \mathrm{~A}\end{array}$ & $\begin{array}{l}\text { Removed from Service \$ } \\
\text { Reference ECN } 602514 \\
\text { Reference ECN } 602515\end{array}$ & Removed from Service \\
\hline 22 & \begin{tabular}{|c|} 
Fault Detector \\
$\begin{array}{c}\text { Breaker Fail. Scheme } \\
\text { Bank-3 }\end{array}$ \\
\end{tabular} & $\begin{array}{l}\text { FD- } \\
\text { BFR- } \\
\text { I3 }\end{array}$ & $\begin{array}{l}\text { G.E. } \\
\mathrm{NHC}\end{array}$ & & IZNHCIIAIA & $\begin{array}{c}\text { 3.Phase, 1.0A Fixed } \\
\text { Settings } \\
\text { Target }=0.2 / 2.0 \mathrm{~A}\end{array}$ & $\begin{array}{c}\text { Removed from Service \$ } \\
\text { Reference } \mathrm{FCN} 602514 \\
\text { Reference } \mathrm{ECN} 602515\end{array}$ & Removed from Service \\
\hline 23 & \begin{tabular}{|c|} 
Fault Detector \\
$\begin{array}{c}\text { Breaker Fail. Scheme } \\
\text { Bank-6 }\end{array}$ \\
\end{tabular} & $\begin{array}{l}\text { FD- } \\
\text { BFR- } \\
\text { T6 }\end{array}$ & $\begin{array}{l}\text { G.E. } \\
\text { NHC }\end{array}$ & $1200-5$ & IZNHCIIAIA & $\begin{array}{c}\text { 3-Phase, 1.0A Fixed } \\
\text { Settings } \\
\text { Target }=0.2 / 2.0 \mathrm{~A}\end{array}$ & $\begin{array}{c}\text { 3-Phase, I.0A Fixed } \\
\text { Settings [240A Primary] } \\
\text { Target }=0.2 \mathrm{~A}\end{array}$ & \\
\hline 24 & \begin{tabular}{|c|} 
Fault Detector \\
Breaker Fail. Scheme \\
Bank-7
\end{tabular} & $\begin{array}{l}\text { FD- } \\
\text { BFR- } \\
17\end{array}$ & $\begin{array}{l}\text { G.E. } \\
\mathrm{NHC}\end{array}$ & $1200-5$ & IZNHCIIAIA & $\begin{array}{c}\text { 3-Phase, 1.0A Fixed } \\
\text { Settings } \\
\text { Jarget }=0.2 / 2.0 \mathrm{~A}\end{array}$ & $\begin{array}{c}\text { 3-Phase, 1.0A Fixed } \\
\text { Settings [240A Primary] } \\
\text { Target }=0.2 \mathrm{~A}\end{array}$ & \\
\hline 25 & \begin{tabular}{|c|} 
Fault Detector \\
Breaker Fail. Scheme \\
Benton BIII6 \\
\end{tabular} & $\begin{array}{l}\text { 6D- } \\
\text { BFR- } \\
\text { 8EN }\end{array}$ & W. & $600-5$ & 293B004A14 & $\begin{array}{c}\text { Phase } 0 / \mathrm{C}=2.0-8.0 \mathrm{~A} \\
\text { Ground } 0 / \mathrm{C}=1.0-4.0 \mathrm{~A} \\
\text { Target and Seal- } \mathrm{In}=0.2 / 2.0 \mathrm{~A}\end{array}$ & $\begin{array}{c}\text { Phase } 0 / C=4.0 \mathrm{~A} \\
\text { Ground } 0 / \mathrm{C}=1.0 \mathrm{~A} \\
\text { Target and Seal- } \ln =0.2 \mathrm{~A}\end{array}$ & \\
\hline 26 & $\begin{array}{c}\text { Fault Detector } \\
\text { Breaker Fail. Scheme } \\
\text { W.B. B1107 }\end{array}$ & $\begin{array}{l}\text { FD- } \\
\text { BFR- } \\
\text { W.B. }\end{array}$ & $\begin{array}{l}\text { W. } \\
\text { KC-4 }\end{array}$ & 600.5 & 293B004A14 & $\begin{array}{c}\text { Phase } 0 / \mathrm{C}=2.0-8.0 \mathrm{~A} \\
\text { Ground } 0 / \mathrm{C}=1.0-4.0 \mathrm{~A} \\
\text { Target and Seal- }-\ln =0.2 / 2.0 \mathrm{~A}\end{array}$ & $\begin{array}{c}\text { Phase } 0 / C=4.0 \mathrm{~A} \\
\text { Ground } 0 / \mathrm{C}=1.0 \mathrm{~A} \\
\text { Target and Seal- }-\ln =0.2 \mathrm{~A}\end{array}$ & . \\
\hline 27 & $\begin{array}{l}\text { Circuit Switcher Trip } \\
\text { Blocking Bank-I }\end{array}$ & $\begin{array}{l}\mathrm{SO}- \\
\mathrm{TI}\end{array}$ & $\begin{array}{l}\text { G.E. } \\
\text { PJC }\end{array}$ & $600-5$ & $12 \mathrm{P}] \mathrm{C} 32 \mathrm{~B} 78 \mathrm{~A}$ & $\begin{array}{c}\text { Inst. } 0 / C=20-80 \mathrm{~A} \\
\text { Target and Seal- } \ln =0.2 / 2.0 \mathrm{~A}\end{array}$ & $\begin{array}{c}\text { Inst. } 0 / C=50 \mathrm{~A} \\
6000 \mathrm{~A} \text { Primary } \\
\text { Target and Seal-In }=0.2 \mathrm{~A}\end{array}$ & \\
\hline 28 & $\begin{array}{l}\text { Circuit Switcher Trip } \\
\text { Blocking Bank-2 }\end{array}$ & $\begin{array}{l}50- \\
12\end{array}$ & $\begin{array}{l}\text { G.E. } \\
\text { PJC }\end{array}$ & & 12P]C32B78A & $\begin{array}{c}\text { Inst. } 0 / C=20-80 \mathrm{~A} \\
\text { Target and Seal-In }=0.2 / 2.0 \mathrm{~A}\end{array}$ & $\begin{array}{l}\text { Removed from Service } \\
\text { Reference ECN } 602514 \\
\text { Reference ECN } 602515 \\
\end{array}$ & Removed from Service \\
\hline 29 & $\begin{array}{l}\text { Circuit Switcher Trip } \\
\text { Blocking Bank-3 }\end{array}$ & $\begin{array}{l}50 . \\
13\end{array}$ & $\begin{array}{l}\text { G.E. } \\
\text { PJC }\end{array}$ & & $12 \mathrm{PJC} 32878 \mathrm{~A}$ & $\begin{array}{c}\text { Inst. } 0 / \mathrm{C}=20.80 \mathrm{~A} \\
\text { Target and Seal-In }=0.2 / 2.0 \mathrm{~A}\end{array}$ & $\begin{array}{l}\text { Removed from Service } \\
\text { Reference ECN } 602514 \\
\text { Reference ECN } 602515\end{array}$ & Removed from Service \\
\hline
\end{tabular}




\section{SUBSTATION B3-S4}

\section{AREA}

\begin{tabular}{|c|c|c|c|c|c|c|c|c|}
\hline $\mathrm{No}$ & 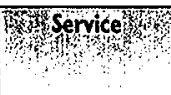 & Tabley & $\begin{array}{l}\text { Rejay: } \\
\text { Type }\end{array}$ & Ratio & $\begin{array}{l}\text { Model or } \\
\text { Style No. }\end{array}$ & Whelay Characteristics $/ 2$ & 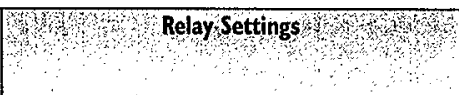 & Wemarks \\
\hline 30 & $\begin{array}{l}\text { Circuit Switcher Trip } \\
\text { Blocking Bank-6 }\end{array}$ & $\begin{array}{l}50- \\
16\end{array}$ & $\begin{array}{l}\text { G.E. } \\
\text { PJC }\end{array}$ & $1200-5$ & 12P]C32B $78 \mathrm{~A}$ & $\begin{array}{c}\text { Inst. } 0 / \mathrm{C}=20-80 \mathrm{~A} \\
\text { Target and Seal- } \ln =0.2 / 2.0 \mathrm{~A}\end{array}$ & $\begin{array}{c}\text { Inst. } 0 / C=25 \mathrm{~A} \\
6000 \mathrm{~A} \text { Primary } \\
\text { Target and Seal- }-\ln =0.2 \mathrm{~A}\end{array}$ & \\
\hline 31 & $\begin{array}{c}\text { Circuit Switcher Trip } \\
\text { Blocking Bank-7 }\end{array}$ & 50. & $\begin{array}{l}\text { G.E. } \\
\text { PJC }\end{array}$ & $1200-5$ & 12P)C32B78A & $\begin{array}{c}\text { Inst. } 0 / \mathrm{C}=20.80 \mathrm{~A} \\
\text { Target and Seal-In }=0.2 / 2.0 \mathrm{~A}\end{array}$ & $\begin{array}{c}\text { Inst. } 0 / C=25 \mathrm{~A} \\
6000 \mathrm{~A} \text { Primary } \\
\text { Target and Seal- } \ln =0.2 \mathrm{~A}\end{array}$ & \\
\hline 32 & $\begin{array}{c}\text { Fault Detector for } \\
\text { Primary Dist. Relays } \\
\text { Benton BIII6 }\end{array}$ & $\begin{array}{l}\text { FD. } \\
\text { PRI.- } \\
\text { BEN }\end{array}$ & $\begin{array}{l}\text { G.E. } \\
P] C\end{array}$ & $1200-5$ & $12 \mathrm{P}] \mathrm{C} 32 \mathrm{C} 34 \mathrm{~A}$ & $\begin{array}{c}\text { Inst. } 0 / \mathrm{C}=1.4 \mathrm{~A} \\
\text { Target and Seal-In }=0.2 / 2.0 \mathrm{~A}\end{array}$ & $\begin{array}{c}\text { Inst. } 0 / \mathrm{C}=1.2 \mathrm{~A} \\
288 \mathrm{~A} \text { Primary } \\
\text { Jarget and Seal- } \mathrm{ln}=2.0 \mathrm{~A}\end{array}$ & \\
\hline 33 & $\begin{array}{l}\text { Fault Detector for } \\
\text { Primary Dist. Relays } \\
\text { W.B. B1107 }\end{array}$ & $\begin{array}{l}\text { FD- } \\
\text { PRI.- } \\
\text { W.B: }\end{array}$ & $\begin{array}{l}\overline{G . E .} \\
\text { PJC }\end{array}$ & $1200-5$ & $12 \mathrm{P}] \mathrm{C} 32 \mathrm{C3} 4 \mathrm{~A}$ & $\begin{array}{c}\text { Inst. } 0 / \mathrm{C}=1.4 \mathrm{~A} \\
\text { Target and Seal- } \ln =0.2 / 2.0 \mathrm{~A}\end{array}$ & $\begin{array}{c}\text { Inst. } 0 / C=1.8 \mathrm{~A} \\
432 \mathrm{~A} \text { Primary } \\
\text { Targẹt and Seal-In }=2.0 \mathrm{~A}\end{array}$ & \\
\hline 34 & $\begin{array}{l}\text { Fault Detector for } \\
\text { B.U. Dist. Relays } \\
\text { Benton BIIl6 }\end{array}$ & $\begin{array}{l}\text { FD. } \\
\text { B.U.- } \\
\text { BEN }\end{array}$ & $\begin{array}{l}\text { G.E. } \\
\text { PJC }\end{array}$ & 1200.5 & $12 P] C 32 C 34 A$ & $\begin{array}{c}\text { Inst. } 0 / \mathrm{C}=1.4 \mathrm{~A} \\
\text { Target and Seal-In }=0.2 / 2.0 \mathrm{~A}\end{array}$ & $\begin{array}{c}\text { Inst. } 0 / \mathrm{C}=1.2 \mathrm{~A} \\
288 \mathrm{~A} \text { Primary } \\
\text { Target and Seal- }-\mathrm{n}=2.0 \mathrm{~A}\end{array}$ & \\
\hline 35 & $\begin{array}{l}\text { Fault Detector for } \\
\text { B.U. Dist. Relays } \\
\text { W.B. B } 1107\end{array}$ & $\begin{array}{l}\text { FD. } \\
\text { B.U.- } \\
\text { W.B. }\end{array}$ & $\begin{array}{l}\text { G.E. } \\
\text { PJC }\end{array}$ & $1200-5$ & {$[2 \mathrm{P}] \mathrm{C} 32 \mathrm{C} 34 \mathrm{~A}$} & $\begin{array}{c}\text { Inst. } 0 / C=1.4 \mathrm{~A} \\
\text { Target and Seal- }-\ln =0.22 .0 \mathrm{~A}\end{array}$ & $\begin{array}{c}\text { Inst. } 0 / C=1.8 \mathrm{~A} \\
432 \mathrm{~A} \text { Primary } \\
\text { Target and Seal-In }=2.0 \mathrm{~A}\end{array}$ & . \\
\hline $\begin{array}{l}36 \\
37 \\
38 \\
\end{array}$ & $\begin{array}{l}\text { II5-kV Bank No. I } \\
\text { O/C. Relays }\end{array}$ & $\begin{array}{l}51- \\
\text { II }\end{array}$ & $\begin{array}{l}\text { G.E. } \\
\text { IAC }\end{array}$ & $600-5$ & 121AC77A801A & $\begin{array}{c}\text { Time } 0 / C=0.5-4 \mathrm{~A} \\
\text { Target and Seal- } \ln =0.2 / 2.0 \mathrm{~A}\end{array}$ & $\begin{array}{c}\text { Time } 0 / \mathrm{C}=2 \mathrm{~A} \\
\text { T. } 0 .=6 \\
\text { Target and Seal- } \mathrm{In}=0.2 \mathrm{~A}\end{array}$ & $1.15 \mathrm{sec} @ 10 \mathrm{~A}$ \\
\hline $\begin{array}{l}39 \\
40 \\
41\end{array}$ & $\begin{array}{l}\text { II5-kV Bank No.2 } \\
\text { O/C. Relays }\end{array}$ & $\begin{array}{l}51- \\
72\end{array}$ & $\begin{array}{l}\text { G.E. } \\
\text { IAC }\end{array}$ & $1200-5$ & I2IAC77A80IA & $\begin{array}{c}\text { Time } 0 / C=0.5 .4 \mathrm{~A} \\
\text { Target and Seal- } \mathrm{In}_{\mathrm{n}}=0.2 / 2.0 \mathrm{~A}\end{array}$ & $\begin{array}{c}\text { Time } 0 / C=0.5 \mathrm{~A} \\
\text { T.D. }=6 \\
\text { Target and Seal- } \mathrm{In}=0.2 \mathrm{~A}\end{array}$ & $0.35 \mathrm{sec} @ 5.0 \mathrm{~A}$ \\
\hline \begin{tabular}{l|}
42 \\
43 \\
44 \\
\end{tabular} & $\begin{array}{l}\text { IIS-kV Bank No. } 3 \\
\text { O/C. Relays }\end{array}$ & $\begin{array}{l}51- \\
\text { T3 }\end{array}$ & $\begin{array}{l}\text { G.E. } \\
\text { IAC }\end{array}$ & $600-5$ & I21AC77A80IA & $\begin{array}{c}\text { Time } 0 / C=0.5-4 \mathrm{~A} \\
\text { Jarget and Seal- } \mathrm{In}=0.2 / 2.0 \mathrm{~A}\end{array}$ & $\begin{array}{c}\text { Time } 0 / C=2 \mathrm{~A} \\
\text { T.D. }=6 \\
\text { Jarget and Seal- } \ln =0.2 \mathrm{~A}\end{array}$ & $0.33 \mathrm{sec} @ 10 \mathrm{~A}$ \\
\hline $\begin{array}{l}45 \\
46 \\
47 \\
\end{array}$ & $\begin{array}{l}\text { J15-kV Bank No.6 } \\
\text { O/C. Relays }\end{array}$ & $\begin{array}{l}51- \\
16\end{array}$ & $\begin{array}{l}\text { G.E. } \\
\text { IAC }\end{array}$ & $1200-5$ & I2IAC77A801A & $\begin{array}{c}\text { Time } 0 / C=0.5-4 \mathrm{~A} \\
\text { Target and Seal-In }=0.2 / 2.0 \mathrm{~A}\end{array}$ & $\begin{array}{c}\text { Time } 0 / \mathrm{C}=0.5 \mathrm{~A} \\
\text { T.D. }=6 \\
\text { Target and Seal- }-\mathrm{n}=0.2 \mathrm{~A}\end{array}$ & $0.35 \mathrm{sec} @ 5.0 \mathrm{~A}$ \\
\hline
\end{tabular}




\section{SUBSTATION B3-S4}

\section{AREA}

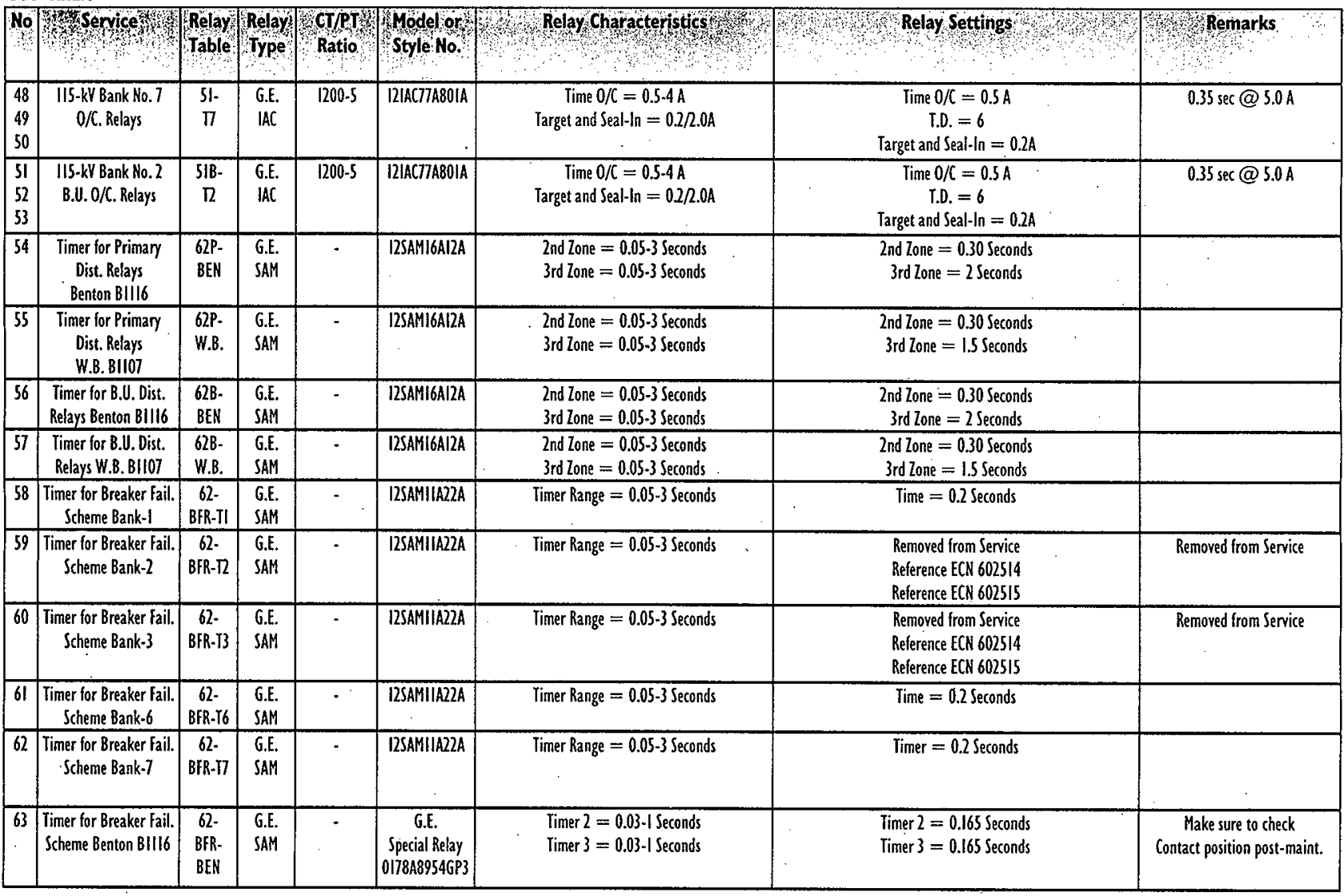




\section{SUBSTATION B3-S4}

\section{AREA}

\begin{tabular}{|c|c|c|c|c|c|c|c|c|}
\hline $\mathrm{No}$ & Whon & Relay & Relay, & Ratio & $\begin{array}{l}\text { Model or } \\
\text { Style Ho. }\end{array}$ & Whelay Characteristics & Who Relay Settings & Remarks \\
\hline 64 & $\begin{array}{l}\text { Timer for Breaker Fail. } \\
\text { Scheme W.B. BII07 }\end{array}$ & $\begin{array}{l}62- \\
\text { BFR- } \\
\text { W.B. }\end{array}$ & $\begin{array}{l}\text { G.E. } \\
\text { SAM }\end{array}$ & - & \begin{tabular}{|c|} 
G.E. \\
Special Relay \\
O178A8954GP3
\end{tabular} & $\begin{array}{l}\text { Timer } 2=0.03-1 \text { Seconds } \\
\text { Timer } 3=0.03-1 \text { Seconds }\end{array}$ & $\begin{array}{l}\text { Timer } 2=0.165 \text { Seconds } \\
\text { Timer } 3=0.165 \text { Seconds }\end{array}$ & $\begin{array}{c}\text { Make sure to check } \\
\text { Contact position post-maint. }\end{array}$ \\
\hline 65 & $\begin{array}{l}\text { II5-kV PRIMARY } \\
\text { Ground Relay } \\
\text { Benton BIII6 }\end{array}$ & $\begin{array}{l}\text { 67GP. } \\
\text { BEN }\end{array}$ & $\begin{array}{l}\text { G.E. } \\
\text { JBCG }\end{array}$ & $\begin{array}{l}1200-5 \\
1000 / 1 V\end{array}$ & $12 \mathrm{JBCGS3M2Y}$ & $\begin{array}{c}\text { Time } 0 / C=0.5-12 \mathrm{~A} \\
\text { Dir. Inst. } 0 / \mathrm{C}=10-80 \mathrm{~A} \\
\text { Non-Dir. Inst. } 0 / \mathrm{C}=6.150 \mathrm{~A} \\
\text { Max Torque Angle }=60 \text { Degree } \\
\text { Target and Seal-In }=0.222 .0 \mathrm{~A}\end{array}$ & $\begin{array}{c}\text { T/O } / \mathrm{C} \text { TAP }=0.5 \mathrm{~A}, \mathrm{~T} . \mathrm{L}=4.25 \\
\text { Dir. Inst. } 0 / \mathrm{C}=29 \mathrm{~A} \\
\text { Non-Dir. Inst. } 0 / \mathrm{C}=8.5 \mathrm{~A} \\
\text { Max Torque Angle }=60 \text { Degree } \\
\text { Target and Seal-In }=2.0 \mathrm{~A}\end{array}$ & $\begin{array}{l}0.61 \mathrm{sec} \\
@ 5.0 \mathrm{~A}\end{array}$ \\
\hline 66 & $\begin{array}{l}\text { II5-kV PRIMARY } \\
\text { Ground Relay } \\
\text { W.B.B1107 }\end{array}$ & $\begin{array}{l}\text { 67GP- } \\
\text { W.B. }\end{array}$ & $\begin{array}{l}\text { G.E. } \\
\text { JBCG }\end{array}$ & $\begin{array}{l}1200.5 \\
1000 / 1 \mathrm{~V}\end{array}$ & [2]BCG53M2Y & $\begin{array}{c}\text { Time } 0 / \mathrm{C}=0.5-12 \mathrm{~A} \\
\text { Dir. Inst. } 0 / \mathrm{C}=10-80 \mathrm{~A} \\
\text { Mon-Dir. Inst. } 0 / \mathrm{C}=6-150 \mathrm{~A} \\
\text { Max Torque Angle }=60 \text { Degree } \\
\text { Target and Seal-In }=0.2 / 2.0 \mathrm{~A}\end{array}$ & $\begin{array}{c}\mathrm{T} / \mathrm{O} / \mathrm{C} \text { TAP }=0.5 \mathrm{~A}, \mathrm{~T} . \mathrm{L}=4 \\
\text { Dir. Inst. } 0 / \mathrm{C}=13 \mathrm{~A} \\
\text { Non-Dir. Inst. } 0 / \mathrm{C}=6.0 \mathrm{~A} \\
\text { Max Torque Angle }=60 \text { Degree } \\
\text { Target and Seal-In }=2.0 \mathrm{~A}\end{array}$ & $\begin{array}{l}0.45 \mathrm{sec} \\
@ 10.0 \mathrm{~A}\end{array}$ \\
\hline 67 & $\begin{array}{l}\text { II5-kV Backup } \\
\text { Ground Relay } \\
\text { Benton Blll6 }\end{array}$ & $\begin{array}{l}67 G B \\
B E N\end{array}$ & $\begin{array}{l}\text { G.E. } \\
\text { JBCG }\end{array}$ & $\begin{array}{l}1200-5 \\
1000 / 1 Y\end{array}$ & [2]BCG53M2Y & $\begin{array}{c}\text { Time } 0 / \mathcal{C}=0.5-12 \mathrm{~A} \\
\text { Dir. Inst. } 0 / \mathcal{C}=10-80 \mathrm{~A} \\
\text { Non-Dir. Inst. } 0 / \mathrm{C}=6.150 \mathrm{~A} \\
\text { Max Torque Angle }=60 \text { Degree } \\
\text { Target and Seal-In }=0.2 / 2.0 \mathrm{~A}\end{array}$ & $\begin{array}{c}\mathrm{T} / 0 / \mathrm{C} \text { TAP }=0.5 \mathrm{~A}, \mathrm{~T} . \mathrm{L}=4.25 \\
\text { Dir. Inst. } 0 / \mathrm{C}=29 \mathrm{~A} \\
\text { Non-Dir. Inst. } 0 / \mathrm{C}=8.5 \mathrm{~A} \\
\text { Max Torque Angle }=60 \text { Degree } \\
\text { Target and Seal-In }=2.0 \mathrm{~A}\end{array}$ & $\begin{array}{l}0.61 \mathrm{sec} \\
@ 5.0 \mathrm{~A}\end{array}$ \\
\hline 68 & $\begin{array}{l}\text { II5-kV Backup } \\
\text { Ground Relay } \\
\text { W.B. BII07 }\end{array}$ & $\begin{array}{l}\text { 67G8- } \\
\text { W.B. }\end{array}$ & $\begin{array}{l}\text { G.E. } \\
\text { JBCG }\end{array}$ & $\begin{array}{l}1200.5 \\
1000 / 1 V\end{array}$ & $12 \mathrm{JCG} 53 \mathrm{M} 2 \mathrm{Y}$ & $\begin{array}{c}\text { Time } 0 / C=0.5-12 \mathrm{~A} \\
\text { Dir. Inst. } 0 / \mathrm{C}=10-80 \mathrm{~A} \\
\text { Non-Dir. Inst. } 0 / \mathrm{C}=6.150 \mathrm{~A} \\
\text { Max Torque Angle }=60 \text { Degree } \\
\text { Target and Seal-In }=0.2 / 2.0 \mathrm{~A}\end{array}$ & $\begin{array}{c}\mathrm{T} / 0 / \mathrm{C} \mathrm{TAP}=0.5 \mathrm{~A}, \mathrm{~T} . \mathrm{L} .=4 \\
\text { Dir. Inst. } 0 / \mathrm{C}=13 \mathrm{~A} \\
\text { Non-Dir. Inst. } 0 / \mathrm{C}=6 \mathrm{~A} \\
\text { Max Torque Angle }=60 \text { Degree } \\
\text { Target and Seal-In }=2.0 \mathrm{~A}\end{array}$ & $\begin{array}{l}0.45 \mathrm{sec} \\
@ 10.0 \mathrm{~A}\end{array}$ \\
\hline 69 & $\begin{array}{l}\text { Automatic Reclosing } \\
\text { Relay Benton BIII6 }\end{array}$ & $\begin{array}{l}79- \\
\text { BEN }\end{array}$ & $\begin{array}{l}\text { G.E. } \\
\text { NSR }\end{array}$ & • & |2NSR2IG2A & & $\begin{array}{l}\text { Single-Shot Reclosing } \\
\text { After 1.5 Seconds }\end{array}$ & $:$ \\
\hline 70 & $\begin{array}{l}\text { Auto. Reclosing } \\
\text { Relay W.B. Bi107 }\end{array}$ & $\begin{array}{l}79 . \\
\text { W.B. }\end{array}$ & $\begin{array}{l}\text { G.E. } \\
\text { NSR }\end{array}$ & * & 12NSR21G2A & & $\begin{array}{l}\text { Single-Shot Reclosing } \\
\text { After I.S Seconds }\end{array}$ & \\
\hline $\begin{array}{l}71 \\
72 \\
73\end{array}$ & $\begin{array}{l}\text { IIS-kV Bus No. I } \\
\text { DIFF. Relays }\end{array}$ & $\begin{array}{l}\text { B7BI- } \\
A \cdot B \cdot C\end{array}$ & $\begin{array}{l}\text { G.E. } \\
\text { PVD }\end{array}$ & $1200-5$ & 12PYD2IDIA & $\begin{array}{l}120 \mathrm{Y}, 60 \mathrm{~Hz}, 87 \mathrm{~L}=75-500 \mathrm{~V}, \\
87 \mathrm{H}=2.50 \mathrm{~A} \text {, Single-Phase, } \\
\text { Target and Seal- } \mathrm{In}=0.2 / 2.0 \mathrm{~A}\end{array}$ & $\begin{array}{c}87 \mathrm{~L}=500 \text { Yolts } \\
87 \mathrm{H}=40 \text { Amps } \\
\text { Target and Seal-in }=0.2 \mathrm{~A}\end{array}$ & $\begin{array}{l}\text { Set Tap@ } \\
87 \mathrm{~L}=\text { High } \\
87 \mathrm{H}=\text { Low }\end{array}$ \\
\hline
\end{tabular}




\section{SUBSTATION B3-S4}

\section{AREA}

\begin{tabular}{|c|c|c|c|c|c|c|c|c|}
\hline $\mathrm{No}$ & Whervicens & Tablay & Relay & Ratio & $\begin{array}{l}\text { Modelor } \\
\text { Style No. }\end{array}$ & Welay Characteristics & 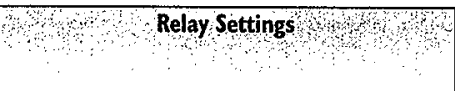 & Whemarks \\
\hline \begin{tabular}{l|}
74 \\
75 \\
76
\end{tabular} & $\begin{array}{l}\text { II5-kV Bus Mo. } 2 \\
\text { DIFF. Relays }\end{array}$ & $\begin{array}{l}87 B 2- \\
A-B-C\end{array}$ & $\begin{array}{l}\text { G.E. } \\
\text { PYD }\end{array}$ & $1200-5$ & I2PVD21DIA & $\begin{array}{c}120 \mathrm{O}, 60 \mathrm{~Hz}, 87 \mathrm{~L}=75-500 \mathrm{Y}, \\
87 \mathrm{H}=2-50 \mathrm{~A} \text {, Single-Phase, } \\
\text { Target and Seal- } \mathrm{In}=0.2 / 2.0 \mathrm{~A}\end{array}$ & $\begin{array}{c}87 \mathrm{~L}=255 \text { VOLTS } \\
87 \mathrm{H}=4.0 \mathrm{AMPS} \\
\text { Target and Seal-ln }=0.2 \mathrm{~A}\end{array}$ & $\begin{array}{l}\text { Set Tap@ } \\
87 \mathrm{~L}=\text { High } \\
87 \mathrm{H}=\text { Low }\end{array}$ \\
\hline \begin{tabular}{l|}
77 \\
78 \\
79
\end{tabular} & $\begin{array}{l}\text { Transformer Diff. } \\
\text { Relay Bank-I }\end{array}$ & $\begin{array}{l}87 . \\
\mathrm{TI}\end{array}$ & $\begin{array}{l}\text { G.E. } \\
\text { BDD }\end{array}$ & $\begin{array}{l}200-5 \\
\text { H.Y. } \\
1000-5 \\
\text { L.Y. } \\
\end{array}$ & |2BDDI6B||A & $\begin{array}{c}\text { Three Winding Restraints, } \\
\text { 2.9-8.7A Taps, } \\
\text { I5-25-40\% Sensitivity } \\
\text { Adjustments [Slope], }\end{array}$ & $\begin{array}{l}\text { H.Y. TAP }=2.9 \mathrm{~A} \\
\text { L.Y. TAP }=8.7 \mathrm{~A} \\
S L O P E=25 \%\end{array}$ & \\
\hline $\begin{array}{l}80 \\
81 \\
82\end{array}$ & $\begin{array}{l}\text { Transformer Diff. } \\
\text { Relay Bank-3 }\end{array}$ & $\begin{array}{l}87- \\
13\end{array}$ & $\begin{array}{l}\text { G.E. } \\
\text { BDD }\end{array}$ & $\begin{array}{l}100-5 \\
\text { H.Y. } \\
1500-5 \\
\text { L.Y. }\end{array}$ & I2BDDI6BIIA & $\begin{array}{l}\text { Three Winding Restraints, } \\
\text { 2.9-8.7A Taps, } \\
\text { 15-25-40\% Sensitivity } \\
\text { Adjustments [Slope], }\end{array}$ & $\begin{array}{l}\text { H.Y. TAP }=5.0 \mathrm{~A} \\
\text { L.Y. TAP }=5.0 \mathrm{~A} \\
\text { SLOPE }=25 \%\end{array}$ & . \\
\hline $\begin{array}{l}83 \\
84 \\
85\end{array}$ & $\begin{array}{l}\text { Transformer Diff. } \\
\text { Relay Bank-6 }\end{array}$ & $\begin{array}{l}87- \\
16\end{array}$ & $\begin{array}{l}\text { G.E. } \\
\text { BDD }\end{array}$ & $\begin{array}{l}200-5 \text { H.Y.Y. } \\
\text { 2000-5 L.Y. }\end{array}$ & |2BDO|6B||A & $\begin{array}{c}\text { Three Winding Restraints, } \\
\text { 2.9-8.7A Taps, } \\
\text { I5-25-40\% Sensitivity } \\
\text { Adjustments [Slope], }\end{array}$ & $\begin{array}{c}\text { H.V. TAP }=3.2 \mathrm{~A} \\
\text { L.Y. TAP }=8.7 \mathrm{~A} \\
\text { SLOPE }=25 \%\end{array}$ & . \\
\hline $\begin{array}{l}86 \\
87 \\
88\end{array}$ & $\begin{array}{l}\text { Transformer Diff. } \\
\text { Relay Bank-7 }\end{array}$ & $\begin{array}{l}87- \\
7 !\end{array}$ & $\begin{array}{l}\text { G.E. } \\
\text { BDD }\end{array}$ & $\begin{array}{l}\text { 200-5 H.Y. } \\
\text { 2000-5 L.Y. }\end{array}$ & 12BDDI6BIIA & $\begin{array}{l}\text { Three Winding Restraints, } \\
\text { 2.9-8.7A Taps, } \\
\text { I5-25-40\% Sensitivity } \\
\text { Adjustments [Slope], }\end{array}$ & $\begin{array}{l}\text { H.Y. TAP }=3.2 \mathrm{~A} \\
\text { L.Y. TAP }=8.7 \mathrm{~A} \\
\text { SLOPE }=25 \%\end{array}$ & . \\
\hline
\end{tabular}


SUBSTATION A - 7

IOOKW AREA

\begin{tabular}{|c|c|c|c|c|c|c|c|c|c|c|c|c|c|c|c|}
\hline Service & $\begin{array}{l}\text { Breaker or } \\
\text { Cubicle No. }\end{array}$ & Ratio & $\begin{array}{l}\text { Phase or } \\
\text { Ground } \\
\end{array}$ & Mfrs & Type & $\begin{array}{l}\text { Model or } \\
\text { style No }\end{array}$ & $\begin{array}{l}\text { Time } 0 / C \\
\text { Range }\end{array}$ & $\begin{array}{l}\text { INST } \\
\text { Range }\end{array}$ & Tap & $\begin{array}{c}\text { Primary } \\
\text { Amps }\end{array}$ & Time & $\begin{array}{l}\text { Test } \\
\text { Amps }\end{array}$ & $\begin{array}{l}\text { Time in } \\
\text { Seconds }\end{array}$ & Inst & \begin{tabular}{|c|} 
Primary \\
Amps
\end{tabular} \\
\hline \multirow{2}{*}{$\begin{array}{l}\text { Incoming Breaker } \\
\text { Bus No.l }\end{array}$} & \multirow[t]{2}{*}{$07 \times 100$} & \multirow[t]{2}{*}{$2000-5$} & Phase & G.E. & $B A C$ & I2IAC53AIA & $4-16$ & - & 5 & 2000 & 4 & 21.5 & 1.30 & - & . \\
\hline & & & Ground & G.E. & IAC & $121 \mathrm{AC} 77 \mathrm{~B} 803 \mathrm{~A}$ & $0.5-4$ & $2-16$ & 0.5 & 200 & 10 & 5 & 0.6 & - & . \\
\hline \multirow{2}{*}{$\begin{array}{l}\text { Inçoming Breaker } \\
\text { Bus Ho.2 }\end{array}$} & \multirow[t]{2}{*}{$07 \times 200$} & \multirow[t]{2}{*}{$2000-5$} & Phase & G.E. & $\overline{I A C}$ & I21AC53AIA & $4-16$ & - & 5 & 2000 & 4 & 21.5 & 1.30 & - & 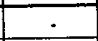 \\
\hline & & & Ground & G.E. & IAC & $121 \mathrm{AC77B803A}$ & $0.5-4$ & $2 \cdot 16$ & 0.5 & 200 & 10 & 5 & 0.6 & - & \\
\hline \multirow{2}{*}{$\begin{array}{l}\text { Bus Tie Breakers } \\
\text { C } 7 \times 6 / C 7 \times 7\end{array}$} & \multirow{2}{*}{$\begin{array}{l}67 \times 6 \\
67 \times 7\end{array}$} & \multirow[t]{2}{*}{$2000-5$} & Phase & G.E. & $\mid A C$ & I2IAC53AIA & 4.16 & - & 4 & 1600 & 3.8 & 21.5 & 0.88 & - & \\
\hline & & & Ground & - & - & - & - & - & - & - & - & - & $=$ & - & - \\
\hline \multirow{2}{*}{$\begin{array}{c}\text { CTX10 } \\
100 K-N-D \cdot F-H\end{array}$} & \multirow[t]{2}{*}{$67 \times 10$} & \multirow[t]{2}{*}{600.5} & Phase & G.E. & IAC & 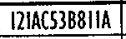 & $1.5-12$ & $10-80$ & 5 & 600 & 3 & - & . & 25 & 3000 \\
\hline & & & Ground & G.E. & IAC & 121AC77BBO3A & $0.5-4$ & 2.16 & 2 & 240 & 2 & - & - & 12.5 & 1500 \\
\hline \multirow{2}{*}{$\begin{array}{l}\text { C7XI } \\
\text { feeder to lookW } \\
\text { XFMR C6787P }\end{array}$} & \multirow[t]{2}{*}{$67 \times 1$} & \multirow[t]{2}{*}{$300-5$} & Phase & G.E. & IAC & 121AC53B27A & $4-16$ & $\begin{array}{l}40- \\
160 \\
\end{array}$ & 4 & 240 & 2 & $\cdot$ & - & 40 & 2400 \\
\hline & & & Ground & G.E. & IAC & 12LAC77B803A & $0.5-4$ & $2-16$ & 1 & 60 & 2 & $\overline{-}$ & $\cdot$ & 10 & 600 \\
\hline \multirow{2}{*}{$\begin{array}{c}\text { C7XI2 } \\
\text { Feeder to 100KE } \\
\text { XFMR C2707D4, } \\
\text { C2708D4, C6667P }\end{array}$} & \multirow[t]{2}{*}{ C7X12 } & \multirow[t]{2}{*}{$300-5$} & Phase & G.E. & IAC & $121 \mathrm{AC} 53 \mathrm{~B} 27 \mathrm{~A}$ & $4-16$ & $\begin{array}{l}40- \\
160\end{array}$ & 10 & 600 & 4 & $\cdot$ & - & 160 & 9600 \\
\hline & & & Ground & G.E. & IAC & 121AC77B803A & $0.5-4$ & 2.16 & 3 & 180 & 9 & & . & $\cdot$ & - \\
\hline \multirow{2}{*}{$\begin{array}{c}C 7 \times 14 \\
\text { Feeder to 100B }\end{array}$} & \multirow[t]{2}{*}{ C7X14 } & \multirow[t]{2}{*}{$300-5$} & Phase & Basler & $B E I$ & BE1-5IB7 & \multicolumn{9}{|c|}{ Tap $=10$, Time Diai $=5$, Extremely Inverse Curve " $"$ ", Instantaneous $=50 \mathrm{~A}$ (3000A Primary) } \\
\hline & & & Ground & BASLER & $\mathrm{BEI}$ & BEI-5IB7 & \multicolumn{9}{|c|}{ Tap $=5$, Time Oial $=1$, Extremely Inverse Curve, " $C$ " Instantaneous $=25 \mathrm{~A}$ (1500A Primary) } \\
\hline \multirow{2}{*}{$\begin{array}{c}\text { 13.8-kV Bus } \\
\text { Differential Relays } \\
\text { Bus Nos. I and 2 }\end{array}$} & & \multirow[t]{2}{*}{1500.5} & & G.E. & PVD & I2PVDIICIA & \multicolumn{4}{|c|}{$87 \mathrm{~L}=120$ Volts } & \multicolumn{5}{|c|}{$87 \mathrm{H}=3.5 \mathrm{Amps}$} \\
\hline & & & & G.E. & PVD & I2PWDIICIA & \multicolumn{4}{|c|}{$87 \mathrm{~L}=120$ Volts } & \multicolumn{5}{|c|}{$87 \mathrm{H}=3.5 \mathrm{Amps}$} \\
\hline \multirow{2}{*}{$\begin{array}{l}\text { Transformer Differential } \\
\text { Relays }[13.8-4.16 \mathrm{kV}]\end{array}$} & & $14400-120 \mathrm{~V}$ & & G.E. & Pfy & $12 P \mathrm{P} V 1 \mathrm{ASIA}$ & & P.U. $=80 \mathrm{~V}$ & Volts & & & & $0.0 .=75 \mathrm{~V}_{0}$ & & \\
\hline & & & & G.E. & PJV & I2PJVIIASIA & & P.U. $=80$ & Volts & & & & D. $0 .=75 \mathrm{Y}_{0}$ & & \\
\hline $\begin{array}{l}\text { Autoreclosing } \\
\text { Relays }\end{array}$ & $67 \times 10 \& C 7 \times 14$ & & & & tme & eous & for t & trip after fa & ult. $\mathbf{R}$ & osi & & 15 & seconds. I & & \\
\hline
\end{tabular}




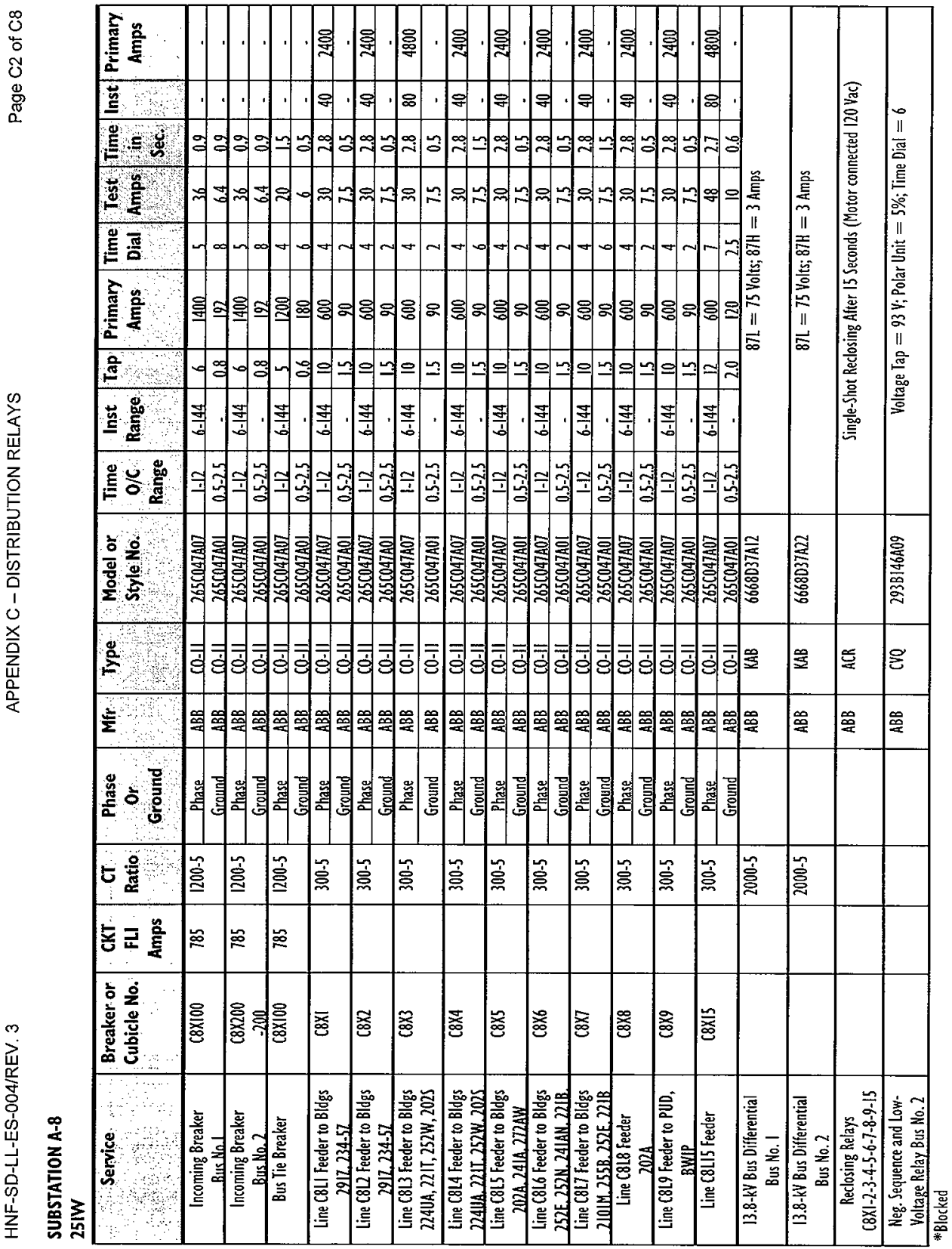




\section{SUBSTATION B3-S4}

300 AREA

\begin{tabular}{|c|c|c|c|c|c|c|c|c|c|c|c|c|c|c|c|c|}
\hline Service & $\begin{array}{l}\text { Breaker } \\
\text { or Cubicle } \\
\text { No }\end{array}$ & \begin{tabular}{|c|} 
hp \\
or \\
KVA \\
\end{tabular} & $\begin{array}{c}\text { CKT } \\
\text { FLI } \\
\text { Amps } \\
\end{array}$ & $\begin{array}{l}\text { CT } \\
\text { Ratio }\end{array}$ & $\begin{array}{l}\text { Phase } \\
\text { or } \\
\text { Ground }\end{array}$ & Mfr & Type & $\begin{array}{l}\text { Model or } \\
\text { Style No. }\end{array}$ & $\begin{array}{l}\text { Time } \\
0 / \mathrm{C} \\
\text { Range }\end{array}$ & $\begin{array}{c}\text { Inst } \\
\text { Range }\end{array}$ & Tap & $\begin{array}{l}\text { Primary } \\
\text { Amps }\end{array}$ & Dime & Inst & $\begin{array}{l}\text { Primary } \\
\text { Amps }\end{array}$ & $\begin{array}{l}\text { Setting } \\
\text { Notes }\end{array}$ \\
\hline \multirow{2}{*}{$\begin{array}{c}\text { Incoming Breaker } \\
\text { Bank No. I }\end{array}$} & \multirow{2}{*}{$\begin{array}{c}C 3 \times 100 \\
F / R\end{array}$} & \multirow{2}{*}{\begin{tabular}{c|}
12 \\
MYA
\end{tabular}} & \multirow[t]{2}{*}{500} & \multirow[t]{2}{*}{$1000-5$} & Phase & G.E. & IAC & I2IAC53AIOIA & $4-16$ & - & 4 & 800 & 9 & - & - & \\
\hline & & & & & Ground & G.E. & IAC & I2IAC77B803A & 0.5 .4 & $2-16$ & 4 & 800 & 10 & * & - & \\
\hline \multirow{2}{*}{$\begin{array}{c}\text { Incoming Breaker } \\
\text { Bank No. } 2\end{array}$} & \multirow{2}{*}{$\begin{array}{c}\mathrm{C} 3 \times 200 \\
\mathrm{~F} / \mathrm{R}\end{array}$} & \multirow{2}{*}{$\begin{array}{c}6 \\
\text { MYA } \\
\end{array}$} & \multirow[t]{2}{*}{250} & \multirow[t]{2}{*}{$600-5$} & Phase & G.E. & IAC & I2IACS3A|0|A & $4-16$ & - & 5 & 600 & 10 & - & - & \\
\hline & & & & & Ground & G.E. & IAC & 121AC77B803A & $0.5-4$ & $2-16$ & 4 & 480 & 10 & * &. & \\
\hline \multirow{2}{*}{$\begin{array}{c}\text { Incoming Breaker } \\
\text { Bank №. } 3\end{array}$} & \multirow{2}{*}{$\begin{array}{c}\mathrm{C} 3 \times 300 \\
\mathrm{~F} / \mathrm{R}\end{array}$} & \multirow{2}{*}{\begin{tabular}{|c|}
12 \\
MYA \\
\end{tabular}} & \multirow[t]{2}{*}{500} & \multirow[t]{2}{*}{$1500-5$} & Phase & G.E. & IAC & |2|AC53A2A & $1.5-6$ & - & 3 & 900 & 10 & . & - & \\
\hline & & & & & Ground & G.E. & $\mathrm{IAC}$ & $121 \mathrm{AC} 77 \mathrm{~B} 803 \mathrm{~A}$ & $0.5-4$ & $2-16$ & 3 & 900 & 10 & * & - & \\
\hline \multirow[t]{2}{*}{ C3LI } & \multirow[t]{2}{*}{ C3XI } & & & \multirow[t]{2}{*}{$600-5$} & Phase & G.E. & $\mathrm{IAC}$ & I2IAC53BI04A & $4-16$ & - & 4 & 480 & 9 & - & - & \multirow{2}{*}{$\begin{array}{l}\text { Coordinate } \\
200 E \text { fuse }\end{array}$} \\
\hline & & & & & Ground & G.E. & $\mathrm{IAC}$ & 121AC77B803A & $0.5-4$ & $2-16$ & 4 & 480 & 7 & $*$ & - & \\
\hline \multirow[t]{2}{*}{ C3L2 } & \multirow[t]{2}{*}{$03 \times 2$} & & & \multirow[t]{2}{*}{$600-5$} & Phase & G.E. & IAC & 121AC53B104A & 4.16 & - & 4 & 480 & 9 & - & - & \multirow{2}{*}{$\begin{array}{l}\text { Coordinate } \\
200 \text { f fuse }\end{array}$} \\
\hline & & & & & Ground & G.E. & $\mathrm{IAC}$ & 121AC77B803A & $0.5-4$ & $2-16$ & 4 & 480 & 7 & * & - & \\
\hline \multirow[t]{2}{*}{$C 313$} & \multirow[t]{2}{*}{ C3)3 } & & & \multirow[t]{2}{*}{$600-5$} & Phase & G.E. & $I A C$ & |2|AC53B|04A & $4-16$ & - & 4 & 480 & 9 & - & - & \multirow{2}{*}{$\begin{array}{l}\text { Coordinate } \\
200 \text { fuse }\end{array}$} \\
\hline & & & & & Ground & G.E. & IAC & I21AC77B803A & $0.5-4$ & $2-16$ & 4 & 480 & 7 & * & - & \\
\hline C3L4 & C3)4 & & & $600-5$ & Phase & G.E. & $I A C$ & |2|AC53B8||A & $1.5-12$ & $10-80$ & 4 & 480 & 9 & * & - & Coordinate \\
\hline & & & & & Ground & G.E. & IAC & 121AC77B803A & $0.5-4$ & $2-16$ & 4 & 480 & 7 & * & - & $200 E$ fuse \\
\hline C3L5 & $63 \times 5$ & & & $300-5$ & Phase & G.E. & IAC & |21AC53B2R & $1.5-12$ & $10-40$ & 6 & 360 & 10 & 30 & 1800 & Automatic \\
\hline Emergency Backup to fFTF & & & & & Ground & G.E. & IAC & 121AC77B803A & $0.5-4$ & $2-16$ & 2 & 120 & 5 & 20 & 1200 & Reclose \\
\hline$C 3 L 6$ & $63 \times 6$ & & & $600-5$ & Phase & G.E. & IAC & |2IAC53B8I|A & $1.5-12$ & $10-80$ & 4 & 480 & 9 & * & - & Coordinate \\
\hline & & & & & Ground & G.E. & $\mathrm{IAC}$ & I2IAC53B8IIA & $1.5 \cdot 12$ & $10-80$ & 4 & 480 & 2 & * & - & $200 E$ fuse \\
\hline C3L7 & C3X7 & & & $600-5$ & Phase & G.E. & $\mathrm{IFC}$ & |2|FC53B|A & $1-12$ & $6-150$ & 4 & 480 & 9 & * & - & Coordinate \\
\hline & & & & & Ground & G.E. & $\mathrm{IFC}$ & I2IFC77B2A & $0.5-4$ & $2-50$ & 4 & 480 & 7 & $*$ & - & $200 E$ fuse \\
\hline C3L8 & C3X8 & & & $300-5$ & Phase & G.E. & $\mathrm{IEC}$ & [2|EC53B|A & $1-12$ & $6-150$ & 8 & 480 & 9 & * & - & Coordinate \\
\hline & & & & & Ground & G.E. & $\mathrm{IFC}$ & |2|FC77B2A & $0.5-4$ & $2-50$ & 4 & 240 & 10 & * & - & 200E Fuse \\
\hline Directional O/CRLY & & & & $1000-5$ & Phase & G.E. & $\overline{B B C}$ & I2IBC5IE7A & $4-16$ & - & 4 & 800 & $\mathrm{I}$ & & & \\
\hline Incoming Breaker Bank No.1 & & & & $14400-20 \mathrm{Y}$ & Ground & & & & & & & & & & & \\
\hline $\begin{array}{c}\text { Directional O/CRLY } \\
\text { Incoming Breaker Bank No.2 }\end{array}$ & & & & $\begin{array}{c}600-5 \\
14400-120 V\end{array}$ & $\begin{array}{l}\text { Phase } \\
\text { Ground }\end{array}$ & G.E. & IBC & |2IBC5IE7A & $4-16$ & - & 4 & 480 & $\mathrm{I}$ & & & \\
\hline $\begin{array}{c}\text { Ground Backup } \\
0 / C \text { Relay Bank No. } 1\end{array}$ & & & & & $\begin{array}{l}\text { Phase } \\
\text { Ground } \\
\end{array}$ & G.E. & IAC & 12IAC77B803A & $0.5-4$ & $2-16$ & 4 & & 7 & & & \\
\hline $\begin{array}{c}\text { Ground Backup } \\
\text { O/C Relay Bank No. } 3\end{array}$ & & & & & $\begin{array}{c}\text { Phase } \\
\text { Ground } \\
\end{array}$ & G.E. & IAC & 121AC77B803A & $0.5-4$ & $2-16$ & 4 & & 7 & & & \\
\hline
\end{tabular}




\section{SUBSTATION B3-S4}

300 AREA

\begin{tabular}{|c|c|c|c|c|c|c|c|c|c|c|c|c|c|c|c|c|}
\hline Service & $\begin{array}{r}\text { Breaker } \\
\text { or Cubicle } \\
\text { No. }\end{array}$ & $\begin{array}{c}\text { hp } \\
\text { or } \\
\text { KVA } \\
\end{array}$ & $\begin{array}{l}\text { CKT } \\
\text { FLI } \\
\text { Amps }\end{array}$ & Ratio & $\begin{array}{l}\text { Phase } \\
\text { or } \\
\text { Ground }\end{array}$ & Mfr & Type & $\begin{array}{l}\text { Model or } \\
\text { Style No }\end{array}$ & $\begin{array}{c}\text { Time } \\
\text { O/C } \\
\text { Range }\end{array}$ & $\begin{array}{l}\text { Inst } \\
\text { Range }\end{array}$ & Tap & $\begin{array}{l}\text { Primary } \\
\text { Amps }\end{array}$ & $\begin{array}{l}\text { Time } \\
\text { Dial } \\
\end{array}$ & Inst & Primary & $\begin{array}{l}\text { Setting } \\
\text { Notes }\end{array}$ \\
\hline $\begin{array}{l}\text { Bus Differential Relays } \\
\text { Bus No. } 1 \text { [Front] }\end{array}$ & & & & $2000-5$ & \multicolumn{6}{|c|}{$\begin{array}{c}\text { West. Ca, Single-Phase, } 60-\mathrm{Hz} \text {, Constant } \\
\text { Percentage Differential, } 10 \% \text { Slope. } \\
\text { Style \# 127100IA }\end{array}$} & \multicolumn{5}{|c|}{$\begin{array}{l}\text { Fixed Setting, Min.Trip } \\
\text { Amp.=0.18A@ } 10 \% \text { Slope. }\end{array}$} & \\
\hline $\begin{array}{l}\text { Bus Differential Relays } \\
\text { Bus No. } 2 \text { [Rear] }\end{array}$ & & & & $2000-5$ & \multicolumn{6}{|c|}{$\begin{array}{l}\text { West. Ca, Single-Phase, } 60-\mathrm{Hz} \text {, Constant } \\
\text { Percentage Differential, I0\% Slope. } \\
\text { Style \# I27/00IA }\end{array}$} & \multicolumn{5}{|c|}{$\begin{array}{c}\text { Fixed Setting, Min. Trip } \\
\text { Amp.=0.18A@ @ } 0 \% \text { Slope. }\end{array}$} & \\
\hline $\begin{array}{l}\text { Bus U/N. Relays } \\
\text { Bus No. I [Front] }\end{array}$ & & & & & \multicolumn{6}{|c|}{$\begin{array}{c}\text { 27-1, 27-2, Bus-1, West. CV, 120-V AC, 60-Hz } \\
\text { 50-140 V. Tap Range. } \\
\text { Style \# 1545600 }\end{array}$} & \multicolumn{5}{|c|}{ 60-V. Tap, Time Dial $=10$} & \\
\hline $\begin{array}{l}\text { BUS UN. Relays } \\
\text { Bus No. } 2 \text { [Rear] }\end{array}$ & & & & & \multicolumn{6}{|c|}{$\begin{array}{c}\text { 27-I, 27-2, Bus-2, West. CV, 120-V AC, 60-Hz } \\
\text { 50-140 V. Tap Range. } \\
\text { Style \# I545600 }\end{array}$} & \multicolumn{5}{|c|}{ 60-V. Tap, Time Dial $=10$} & \\
\hline $\begin{array}{c}\text { Recloser on } \\
\text { Line C } 3 \times 5\end{array}$ & $63 \times 5$ & & & & & G.E. & ACR & $\overline{\mid 2 A C R I I B I 4}$ & & & & & & & & \\
\hline
\end{tabular}

* Instantaneous element is blocked. 


\section{Substation C3-3}

300 Area

\begin{tabular}{|c|c|c|c|c|c|c|c|c|c|c|c|c|c|c|}
\hline Servicer, & $\begin{array}{l}\text { Breaker } \\
\text { or Cubicle } \\
\text { No. }\end{array}$ & Ratio & $\begin{array}{l}\text { Phase } \\
\text { or } \\
\text { Ground }\end{array}$ & Mfrom & Type & Model orstyle No & $\begin{array}{l}\text { Time } \\
\text { o/C } \\
\text { Range }\end{array}$ & $\begin{array}{l}\text { Inst } \\
\text { Range }\end{array}$ & Tap & Primary & Time & Inst: & $\begin{array}{l}\text { Primary } \\
\text { Amps }\end{array}$ & Setting Notes \\
\hline \multirow[t]{2}{*}{ Incoming Breaker C3L3 } & C3X91 & \multirow[t]{2}{*}{$600-5$} & Phase & G.E. & IAC & I2IACS3A2A & $1.5-6$ & - & 3 & 360 & 4 & - & - & \\
\hline & $\mathrm{F} / \mathrm{R}$ & & Ground & W. & $\mathrm{CO}$ & $1338968 \mathrm{~A}$ & $0.5-2.5$ & $10-40$ & 2 & 240 & 0.5 & - & $\cdot$ & \\
\hline \multirow[t]{2}{*}{ Incoming Breaker C 3 L4 } & $\mathrm{C} 3 \times 92$ & \multirow[t]{2}{*}{$1500-5$} & Phase & G.E. & IAC & I2IAC53A2A & $1.5-6$ & - & 1 & 300 & 4 & 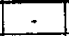 & - & \\
\hline & $F / R$ & & Ground & W. & 60 & $1271197 \mathrm{~A}$ & $0.5-2.5$ & - & 0.8 & 240 & 0.5 & $\cdot$ & - & \\
\hline \multirow[t]{2}{*}{ Incoming Breaker C $3 \mathrm{~L} 6$} & C3X97 & \multirow[t]{2}{*}{$600-5$} & Phase & G.E. & $\mathrm{IAC}$ & I2IAC53B81|A & $1.5-12$ & $10-80$ & 3 & 360 & 4 & * & - & \\
\hline & $E / R$ & & Ground & G.E. & IAC & 121AC53B811A & $1.5-12$ & $10-80$ & 2 & 240 & 0.5 & * & - & \\
\hline \multirow[t]{2}{*}{ Feeder to C3-S11 [3621D] } & \multirow[t]{2}{*}{$03 \times 90$} & \multirow[t]{2}{*}{$200-5$} & Phase & G.E. & IAC & |21AC53B|27A & $4-16$ & $20-80$ & \multicolumn{6}{|c|}{ Relay has been deactivated. } \\
\hline & & & Ground & W. & 10 & $1338968 \mathrm{~A}$ & $0.5-2.5$ & 10.40 & \multicolumn{6}{|c|}{ Relay has been deactivated. } \\
\hline \multirow[t]{2}{*}{ Feeder to [3-59 [337] } & \multirow[t]{2}{*}{ C3X94 } & \multirow[t]{2}{*}{$200-5$} & Phase & G.E. & $\mathrm{IAC}$ & $121 \mathrm{ACS} 3 \mathrm{~B} 26 \mathrm{~A}$ & $1.5-6$ & $20-80$ & \multicolumn{6}{|c|}{ Relay has been deactivated. } \\
\hline & & & Ground & W. & $\mathrm{CO}$ & $1338968 \mathrm{~A}$ & $0.5-2.5$ & 10.40 & \multicolumn{6}{|c|}{ Relay has been deactivated. } \\
\hline \multirow[t]{2}{*}{ Feeder to [3-59 [337] } & \multirow[t]{2}{*}{ C3X95 } & \multirow[t]{2}{*}{$200-5$} & Phase & G.E. & IAC & $121 \mathrm{AC53B} 26 \mathrm{~A}$ & $1.5-6$ & 20.80 & \multicolumn{6}{|c|}{ Relay has been deactivated. } \\
\hline & & & Ground & W. & 60 & $1338968 \mathrm{~A}$ & $0.5-2.5$ & $10-40$ & \multicolumn{6}{|c|}{ Relay has been deactivated. } \\
\hline \multirow[t]{2}{*}{ Feeder to [3-59 [337] } & \multirow[t]{2}{*}{ C3X96 } & \multirow[t]{2}{*}{200.5} & Phase & G.E. & $\mathrm{IAC}$ & 12IAC53B26A & $1.5-6$ & $20-80$ & \multicolumn{6}{|c|}{ Relay has been deactivated. } \\
\hline & & & Ground & $W$. & $C 0$ & $1338968 \mathrm{~A}$ & $0.5-2.5$ & $10-40$ & \multicolumn{6}{|c|}{ Relay has been deactivated. } \\
\hline \multirow{2}{*}{$\begin{array}{l}\text { Feeder to(3-4(EETF), } \\
\text { C3-S13 [FMIT] }\end{array}$} & C3X98 & $300-5$ & Phase & G.E. & IAC & D2IACS3B104A & $4-16$ & $20 \cdot 80$ & \multicolumn{6}{|c|}{ Relay has been deactivated. } \\
\hline & & & Ground & $w$. & $\mathrm{CO}$ & $1338968 \mathrm{~A}$ & $0.5-2.5$ & $10-40$ & & & & $y$ has bee & en deactivated. & \\
\hline Feeder to C3-S6 [331] & C3X99 & $200-5$ & Phase & G.E. & IAC & 12IACS3B811A & $1.5-12$ & $20-80$ & & & & y has bee & en deactivated. & \\
\hline & & & Ground & W. & 50 & $1338968 \mathrm{~A}$ & $0.5-2.5$ & $10-40$ & & & & y has bee & en deactivated. & \\
\hline $\begin{array}{l}\text { 13.8-kV Bus Differential } \\
\text { Bus No. I Rear Bus }\end{array}$ & & $2000-5$ & & W. & $\overline{C A-6}$ & 1543525 & & & & & & & & \\
\hline $\begin{array}{l}\text { 13.8-kV Bus Differential } \\
\text { Bus No. } 2 \text { Front Bus }\end{array}$ & & $2000-5$ & & W. & CA-6 & 1543525 & & & & & & & & \\
\hline Incoming Breaker & C3X97/R $/ R$ & $600-5$ & Phase & G.E. & $\mathrm{IBC}$ & 12IBCS3K3YIA & $4-16$ & $20-80$ & & & & y has bee & en deactivated. & \\
\hline Directional $0 / C$ C316 & & & Ground & W. & IRQ.9 & 774 B238AI4 & $2-6$ & $10-40$ & & & & ay has bee & en deactivated. & \\
\hline Incoming Breaker & C3X91F/R & $600-5$ & Phase & G.E. & $\overline{I B C}$ & $121 B C 53 K 2 A$ & $1.5 \cdot 6$ & - & & & & ay has bee & en deactivated. & \\
\hline Directional O/C C3L3 & & & Ground & & & & & & & & & ay has bee & en deactivated. & \\
\hline Incoming Breaker & $\mathrm{C} 3 \times 92 \mathrm{~F} / \mathrm{R}$ & $1500-5$ & Phase & W. & IRQ-9 & $774 B 238 \mathrm{Al} 4$ & 2.6 & $10-40$ & & & & ay has bee & en deactivated. & \\
\hline Directional $0 / C 3 C L 4$ & & & Ground & & & & & & & & & ay has bee & en deactivated. & \\
\hline
\end{tabular}

- instantaneous element is blocked

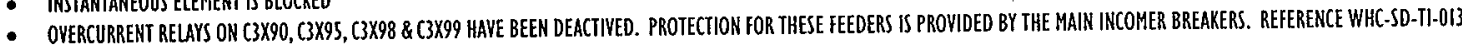

- DIRECTIONAL OYERCURRENT RELAYS ON C3X91, C3X92, AND C3X97 HAVE BEEN DEACTIYATED 


\section{SUBSTATION C3-S4}

300 AREA

\begin{tabular}{|c|c|c|c|c|c|c|c|c|c|c|c|c|c|}
\hline Servicesplest & $\begin{array}{l}\text { Breakeror: } \\
\text { Cubicle No. }\end{array}$ & $\begin{array}{l}\text { GTiving } \\
\text { Ratio }\end{array}$ & $\begin{array}{l}\text { Phiase } \\
\text { or } \\
\text { Ground }\end{array}$ & Mfres & Type & $\begin{array}{r}\text { Model or Style } \\
\text { No. } \\
\text { Nots }\end{array}$ & $\begin{array}{l}\text { Time } \\
\text { 0/C } \\
\text { Range }\end{array}$ & $\begin{array}{l}\text { Inst } \\
\text { Range }\end{array}$ & Tap & Primary & Dial & inst & Primary \\
\hline \multirow{2}{*}{$\begin{array}{c}\text { Incoming Breaker } \\
\text { [C }[\text { LI] }\end{array}$} & \multirow[t]{2}{*}{ C3X131 } & \multirow[t]{2}{*}{$600-5$} & Phase & G.E. & IFC & DIIFCS3B|A & $1-12$ & $6-150$ & & \multicolumn{4}{|c|}{ Relay has been deactivated } \\
\hline & & & Ground & G.E. & IFC & $12 \mathrm{HFC53B2A}$ & $0.5-4.0$ & $2-50$ & & \multicolumn{4}{|c|}{ Relay has been deactivated } \\
\hline \multirow{2}{*}{$\begin{array}{c}\text { Incoming Breaker } \\
\text { [C\L2] }\end{array}$} & \multirow[t]{2}{*}{ C3X138 } & \multirow[t]{2}{*}{600.5} & Phase & G.E. & IFC. & I2IFCS3B|A & $1-12$ & $6-150$ & & \multicolumn{4}{|c|}{ Relay has been deactivated } \\
\hline & & & Ground & G.E. & IFC & $121 F(53 B 2 A$ & $0.5-4.0$ & $2-50$ & & \multicolumn{4}{|c|}{ Relay has been deactivated } \\
\hline \multirow{2}{*}{$\begin{array}{c}\text { Incoming Breaker } \\
{[\mathrm{C}[3]}\end{array}$} & \multirow[t]{2}{*}{ C3X139 } & \multirow[t]{2}{*}{$600-5$} & Phase & G.E. & $\mathrm{IFC}$ & $121 \xi C 53 B \mid A$ & $1-12$ & $6-150$ & & \multicolumn{4}{|c|}{ Relay has been deactivated } \\
\hline & & & Ground & G.E. & IfC & 121EC53B2A & $0.5-4.0$ & 2.50 & & \multicolumn{4}{|c|}{ Relay has been deactivated } \\
\hline \multirow{2}{*}{ Bus Tie Breaker } & \multirow[t]{2}{*}{ C3X135 } & \multirow[t]{2}{*}{$600-5$} & Phase & G.E. & IFC & $121 \mathrm{FC} 53 \mathrm{BIA}$ & $1-12$ & 6.150 & & \multicolumn{4}{|c|}{ Relay has been deactivated } \\
\hline & & & Ground & G.E. & IFC & $121 F C 53 B 2 A$ & $0.5-4.0$ & $2-50$ & & \multicolumn{4}{|c|}{ Relay has been deactivated } \\
\hline \multirow{2}{*}{ Feeder to $(3 \mathrm{~L} 133$} & \multirow[t]{2}{*}{$63 \times 133$} & \multirow[t]{2}{*}{200.5} & Phase & G.E. & IFC & $121 F(53 B \mid A$ & $1-12$ & $6-150$ & 8 & 200 & 5 & * & - \\
\hline & & & Ground & G.E. & IFC & $121 F(53 B 2 A$ & $0.5-4.0$ & 2.50 & 3 & 120 & 2 & * & - \\
\hline \multirow[t]{2}{*}{ Feeder to C CLI37 } & \multirow[t]{2}{*}{ C3X137 } & \multirow[t]{2}{*}{200.5} & Phase & G.E. & IFC & $121 F C 53 B 1 A$ & 1.12 & 6.150 & 8 & 200 & 5 & * & - \\
\hline & & & Ground & G.E. & IFC & $121 F C 53 B 2 A$ & $0.5-4.0$ & $2-50$ & 3 & 120 & 2 & * & - \\
\hline \multirow{2}{*}{ Spare Feeder Breaker } & \multirow[t]{2}{*}{ C3X132 } & \multirow[t]{2}{*}{$600-5$} & Phase & G.E. & IFC & I2IECS3B।A & $1-12$ & $6-150$ &. & - & - & - & - \\
\hline & & & Ground & G.E. & $\mathrm{IFC}$ & $121 F C 53 B 2 A$ & $0.5-4.0$ & $2-50$ & - & - & - & - & - \\
\hline \multirow[t]{2}{*}{ Feeder to C3I134 } & \multirow[t]{2}{*}{ C3X134 } & \multirow[t]{2}{*}{$600-5$} & Phase & G.E. & IfC & 12IFC53BIA & $1-12$ & 6.150 & 3 & 360 & 4 & * & $\therefore$ \\
\hline & & & Ground & G.E. & IFC & $1211 C 53 B 2 \mathrm{~A}$ & $0.5-4.0$ & 2.50 & 1 & 120 & 2 & * & - \\
\hline Feeder to $\mathrm{C} 31136$ & $63 \times 136$ & 600.5 & Phase & G.E. & IFC & I2IFCS3B|A & $1-12$ & $6-150$ & 3 & 360 & 4 & $*$ & + \\
\hline & & & Ground & G.E. & $1 \mathrm{FC}$ & $12 \mathrm{IFC} 53 \mathrm{~B} 2 \mathrm{~A}$ & 0.5 .4 .0 & 2.50 & 1 & 120 & 2 & * & - \\
\hline I3.8-kV Bus Differential Relays & $1 B$ and $7 B$ & $1200-5$ & Bus & G.E. & PVD & I2PVD2IBIA & & 871 & $150 Y_{0}$ & Target & $=0.2 \mathrm{~A}$ & & \\
\hline Bus Nos. I and 2 & & & Diff. & G.E. & PVD & I2PVD2IBIA & & & & & & & \\
\hline
\end{tabular}

* Blocked instantaneous element.

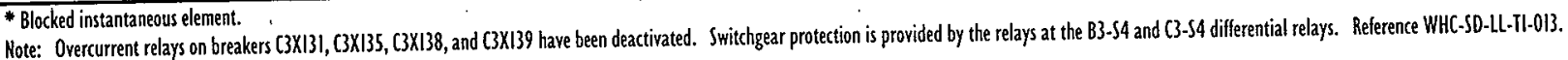




\section{2,4 KV RELAY SETTINGS}

\section{SUBSTATION CB-SI}

200W AREA; 252-W BLDG.

\begin{tabular}{|c|c|c|c|c|c|c|c|c|c|c|c|c|c|c|c|c|c|}
\hline Service & $\begin{array}{c}\text { Breaker or } \\
\text { Cubicle No. } \\
\therefore\end{array}$ & hpor & $\begin{array}{c}\text { CKT } \\
\text { FLI } \\
\text { Amps } \\
\end{array}$ & $\begin{array}{l}\text { CI } \\
\text { Ratio }\end{array}$ & $\begin{array}{r}\text { Phase } \\
\text { or } \\
\text { Ground }\end{array}$ & Mro & Type & $\begin{array}{l}\text { Model } \\
\text { or } \\
\text { Style No. }\end{array}$ & $\begin{array}{c}\text { Time } \\
0 / C \\
\text { Range }\end{array}$ & Range & Tap & $\begin{array}{l}\text { Primary } \\
\text { Amps }\end{array}$ & Díne & $\begin{array}{l}\text { Test } \\
\text { Amps }\end{array}$ & $\begin{array}{l}\text { Time } \\
\text { In } \\
\text { Sec. }\end{array}$ & Inst & \begin{tabular}{|l} 
Primary \\
Amps
\end{tabular} \\
\hline \multirow{2}{*}{$\begin{array}{c}\text { Incoming Breaker } \\
\text { Bus No. } 1\end{array}$} & \multirow[t]{2}{*}{ E8X4 } & \multirow{2}{*}{$\begin{array}{l}3125 \\
\text { KVA }\end{array}$} & \multirow[t]{2}{*}{752} & \multirow[t]{2}{*}{$1000-5$} & PHASE & G.E. & IAC & $121 \mathrm{ACS} \mid \mathrm{B} 802 \mathrm{~A}$ & 2.16 & $0.5-40$ & 6 & 1200 & 5 & 24 & 2.1 & * & $\cdot$ \\
\hline & & & & & GROUND & - & - & - & - & - & - & - & - & - & - & - & - \\
\hline \multirow{2}{*}{$\begin{array}{c}\text { Incoming Breaker } \\
\text { Bus No.2 }\end{array}$} & \multirow[t]{2}{*}{$E 8 \times 6$} & \multirow{2}{*}{$\begin{array}{l}3125 \\
\text { KVA }\end{array}$} & \multirow[t]{2}{*}{752} & \multirow[t]{2}{*}{$1000-5$} & PHASE & G.E. & IAC & I21AC5IB802A & $2-16$ & 0.5 .40 & 6 & 1200 & 5 & 24 & 2.1 & * & - \\
\hline & & & & & GROUND & - & 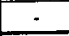 & $\cdot$ & - & - & - & - & - & 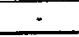 & - & - & $\therefore$ \\
\hline \multirow[t]{2}{*}{ Bus Tie Breaker } & \multirow[t]{2}{*}{$E 8 \times 5$} & & & \multirow{2}{*}{$1000-5$} & PHASE & G.E. & IAC & I21ACSIB802A & $2-16$ & 0.5 .40 & 6 & 1200 & 5 & 24 & 2.1 & * & - \\
\hline & & & & & GROUND & - & 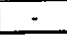 & $\therefore$ & - &. & - & - & - & - & - & - & 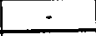 \\
\hline \multirow{2}{*}{$\begin{array}{l}\text { Feeder to BIdgs. } \\
282-W / 283-W\end{array}$} & \multirow[t]{2}{*}{ E8XI } & & & \multirow[t]{2}{*}{$500-5$} & PHASE & G.E. & IAC & B21ACSIB806A & $2-16$ & $10-80$ & 10 & 1000 & 2 & 30 & 1 & * & - \\
\hline & & & & & GROUND & - & - & $\cdot$ & - & $\cdot$ & - & - & - & $\cdot$ & - & - & - \\
\hline \multirow{2}{*}{$\begin{array}{l}\text { Feeder to Bldgs. } \\
282-W / 283-W\end{array}$} & \multirow[t]{2}{*}{ E8X9 } & & & \multirow[t]{2}{*}{$400-5$} & PHASE. & G.E. & $\mathrm{IAC}$ & I2IAC51B806A & $2-16$ & $10-80$ & 12 & 960 & 2 & 36 & 1 & * & - \\
\hline & & & & & GROUND & - & - & - & - & - & . & - & $\div$ & - & - & . & - \\
\hline \multirow{2}{*}{$\begin{array}{l}\text { Feeder to Emergency } \\
\text { Power House }\end{array}$} & \multirow[t]{2}{*}{$E 8 \times 3$} & & & \multirow[t]{2}{*}{$500-5$} & PHASE & G.E. & IAC & I21AC518806A & $2-16$ & $10-80$ & 5 & 500 & 5 & 20 & 2.1 & $*$ & - \\
\hline & & & & & \begin{tabular}{|l|} 
GROUND \\
\end{tabular} & - & - & $\therefore$ & - & - & - & - & - & - & - & - & - \\
\hline \multirow{2}{*}{$\begin{array}{l}\text { Feeder to Emergency } \\
\text { Power House }\end{array}$} & \multirow[t]{2}{*}{ E8X8 } & & & \multirow[t]{2}{*}{$500-5$} & PHASE & G.E. & $\mathrm{IAC}$ & I2IACSIB806A & $2-16$ & $10-80$ & 5 & 500 & 3 & 20 & 2.1 & * & - \\
\hline & & & & & GROUND & - & - & - & - & - & . & - &. & - & $\dot{.}$ & - & - \\
\hline
\end{tabular}

* Block All Inst. Elements 


\section{4-kV RELAY SETTINGS}

\section{SUBSTATION C8-53}

200E AREA; 252-E BLDG.

\begin{tabular}{|c|c|c|c|c|c|c|c|c|c|c|c|c|c|c|c|c|c|}
\hline Service & Breaker or & $\begin{array}{l}\text { hpor } \\
\text { Kva }\end{array}$ & $\begin{array}{c}\text { CKT } \\
\text { FLI } \\
\text { Amps } \\
\end{array}$ & $\begin{array}{l}\text { CTY } \\
\text { Ratio }\end{array}$ & $\begin{array}{l}\text { Phase } \\
\text { or } \\
\text { Ground }\end{array}$ & $\mathrm{Mir}$ & Type & $\begin{array}{l}\text { Model } \\
\text { or } \\
\text { Style No. }\end{array}$ & $\begin{array}{l}\text { Time } \\
0 / C \\
\text { Range }\end{array}$ & $\begin{array}{l}\text { Inst } \\
\text { Range }\end{array}$ & Tap & $\begin{array}{c}\text { Primany } \\
\text { Amps }\end{array}$ & Dial & $\begin{array}{l}\text { Test } \\
\text { Amps }\end{array}$ & $\begin{array}{l}\text { Time } \\
\text { In } \\
\text { Sec. }\end{array}$ & Inst & $\begin{array}{c}\text { Primary } \\
\text { Amps }\end{array}$ \\
\hline \multirow{2}{*}{$\begin{array}{l}\text { Incoming Breaker } \\
\text { Bus No.I }\end{array}$} & \multirow[t]{2}{*}{ E8X56 } & \multirow{2}{*}{$\begin{array}{l}2500 \\
3125\end{array}$} & \multirow{2}{*}{$\begin{array}{l}601 \\
752\end{array}$} & \multirow[t]{2}{*}{$1000-5$} & Phase & G.E. & IAC & $121 \mathrm{ACS} 1 \mathrm{~B} 802 \mathrm{~A}$ & $2-16$ & $0.5-40$ & 6 & 1200 & 5 & 24 & 2.1 & * & - \\
\hline & & & & & Ground & - & - & - & - & - & & . & - & - & - & . & . \\
\hline \multirow{2}{*}{$\begin{array}{c}\text { Incoming Breaker } \\
\text { Bus No. } 2\end{array}$} & \multirow[t]{2}{*}{ E8X54 } & 2500 & 601 & \multirow[t]{2}{*}{$1000-5$} & Phase & G.E. & IAC & I21AC5IB802A & $2: 16$ & $0.5-40$ & 6 & 1200 & 5 & 24 & 2.1 & * & - \\
\hline & & 3125 & 752 & & Ground & - & - & - & - & - & - & - & - & - & - & - & - \\
\hline \multirow{2}{*}{ Bus Tie Breaker } & \multirow[t]{2}{*}{$58 \times 55$} & & & \multirow[t]{2}{*}{1000.5} & Phase & G.E. & IAC & 121ACSIBBO2A & 2.16 & $0.5-40$ & 6 & 1200 & 5 & 24 & 2.1 & * & - \\
\hline & & & & & Ground & - & . & - & - & - & - & - & - & - &. & $\cdot$ & - \\
\hline \multirow{2}{*}{$\begin{array}{c}\text { Feeder to Bldgs. } \\
282-\mathrm{E} / 283-\mathrm{E}\end{array}$} & \multirow[t]{2}{*}{ E8X51 } & & & \multirow[t]{2}{*}{$400-5$} & Phase & G.E. & IAC & 12JAC5IB808A & $2-16$ & $10-80$ & 6 & 480 & 5 & 24 & 2 & $*$ & . \\
\hline & & & & & Ground & - &. &. & - & - & - & - & - & - & - & - & - \\
\hline \multirow{2}{*}{$\begin{array}{c}\text { Feeder to Bldg. } \\
282-E\end{array}$} & \multirow[t]{2}{*}{ E8X52 } & & & \multirow[t]{2}{*}{$400-5$} & Phase & G.E. & $\mathrm{IAC}$ & I2IAC51B808A & 2.16 & $10-80$ & 12 & 960 & 2 & 36 & 1 & * & - \\
\hline & & & & & Ground & - & - & - & - & - & - & - & . & - & . &. & - \\
\hline \multirow{2}{*}{$\begin{array}{c}\text { Feeder to } \\
\text { 284-E Power House }\end{array}$} & \multirow[t]{2}{*}{ E8X59 } & & & \multirow[t]{2}{*}{$300-5$} & Phase & G.E. & $\mathrm{IAC}$ & I2IACSIB806A & 2.16 & $10-80$ & 4 & 240 & 4 & 20 & 1.3 & 33.3 & 1998 \\
\hline & & & & & Ground & - & $\cdot$ & - & - & - &. & - & - & - & . & - & - \\
\hline \multirow{2}{*}{$\begin{array}{c}\text { Feeder to Bldg. } \\
282-\mathrm{E} \\
\end{array}$} & \multirow[t]{2}{*}{ E8X57 } & & & \multirow[t]{2}{*}{$300-5$} & Phase & G.E. & IAC & $121 \mathrm{AC51B806 \textrm {A }}$ & $2-16$ & 10.80 & 16 & 960 & 2 & 48 & 1 & * & - \\
\hline & & & & & Ground & - & : & - & - & - & + & - & - & . & - &. & 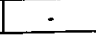 \\
\hline
\end{tabular}

* Block Inst. Elements 